\title{
DESEMPENHO, COMPOSIÇÃO DO LEITE E MECANISMOS ENVOLVIDOS NA DEPRESSÃO DA GORDURA DO LEITE (DGL) DE VACAS RECEBENDO ÁCIDOS LINOLÉICOS CONJUGADOS (CLA) E ÓLEO DE PEIXE NA DIETA
}

\author{
MARCO ANTÔNIO SUNDFELD DA GAMA
}

Tese apresentada à Escola Superior de Agricultura “Luiz de Queiroz”, Universidade de São Paulo, para obtenção do título de Doutor em Agronomia, Área de Concentração: Ciência Animal e Pastagens.

\author{
P I R A C I C A B A
}

Estado de São Paulo - Brasil

Julho - 2004 


\title{
DESEMPENHO, COMPOSIÇÃO DO LEITE E MECANISMOS ENVOLVIDOS NA DEPRESSÃO DA GORDURA DO LEITE (DGL) DE VACAS RECEBENDO ÁCIDOS LINOLÉICOS CONJUGADOS (CLA) E ÓLEO DE PEIXE NA DIETA
}

\author{
MARCO ANTÔNIO SUNDFELD DA GAMA \\ ZOOTECNISTA
}

Orientador: Prof. Dr. DANTE PAZZANESE DUARTE LANNA

Tese apresentada à Escola Superior de Agricultura “Luiz de Queiroz”, Universidade de São Paulo, para obtenção do título de Doutor em Agronomia, Área de Concentração: Ciência Animal e Pastagens.

P I R A C I C A B A

Estado de São Paulo - Brasil

Julho - 2004 


\section{Dados Internacionais de Catalogação na Publicação (CIP) DIVISÃO DE BIBLIOTECA E DOCUMENTAÇÃO - ESALQ/USP}

Gama, Marco Antonio Sundfeld da

Desempenho, composição do leite e mecanismos envolvidos na depressão da gordura do leite (DGL) de vacas recebendo ácidos linoléicos conjugados (CLA) e óleo de peixe na dieta.

$120 \mathrm{p}$.

Tese (doutorado) - - Escola Superior de Agricultura Luiz de Queiroz, 2004. Bibliografia.

1. Ácido linoléico 2. Dieta animal 3. Leite - Composição 4. Metabolismo animal 5. Óleo de peixe 6 . Vaca leiteira I. Título

CDD 636.214 
Muitas vezes as pessoas são egocêntricas, ilógicas e insensatas.

Perdoe-as assim mesmo.

Se você é gentil, as pessoas podem acusá-lo de egoísta, interesseiro.

Seja gentil, assim mesmo.

Se você é um vencedor, terá alguns falsos amigos e alguns inimigos verdadeiros.

Vença assim mesmo.

Se você é honesto e franco as pessoas podem enganá-lo.

Seja honesto assim mesmo.

O que você levou anos para construir, alguém pode destruir de uma hora para outra.

Construa assim mesmo.

Se você tem Paz, é Feliz, as pessoas podem sentir inveja.

Seja Feliz assim mesmo.

Dê ao mundo o melhor de você, mas isso pode nunca ser o bastante.

Dê o melhor de você assim mesmo.

Veja você que no final das contas, é entre você e Deus.

Nunca foi entre você e as outras pessoas.

Madre Tereza de Calcutá

DEDICO esta tese a todas as pessoas que, como a Madre Tereza, sempre acreditaram no amor de Deus e no amor entre as pessoas. 


\section{AGRADECIMENTOS}

Ao professor Dante Pazzanese Duarte Lanna, por estimular a paixão pela pesquisa nos seus orientados e por nos dar a liberdade de expressar as nossas idéias, sem restrições.

Ao grande pesquisador Dr. Mikko Griinari, cuja contribuição para a realização e discussão do dados obtidos no segundo experimento não pode ser estimada.

Aos Professores e amigos Paulo Henrique M. Rodrigues, Paulo R. Leme e Luís Waldemar (Luidi), que foram fundamentais para o sucesso do segundo experimento.

A todos os professores do Curso de Ciência Animal e Pastagens que contribuíram direta ou indiretamente com o meu aprendizado.

Ao professor Júlio Balieiro e à Priscila, pela forma acolhedora com que me receberam na FEOB e ao João Flávio, por ter me confiado a responsabilidade da formação de futuros médicos veterinários.

Ao meu pai, que continua a ser o melhor ser humano que eu conheço após todos estes anos, além de suprir como ninguém as minhas ausências como pai.

À minha mãe, pela paciência e pelo amor.

À minha filha Natália e à minha namorada Sofia, cujo amor dedicado a mim, não pode ser mensurado. 
Ao seu Nelson e à dona Elza, pela paciência de me acolherem em sua casa em muitos fins-de-semana.

Ao Daniel e ao Vicente, que compreendem como poucos o valor de uma amizade, apesar dos meus constantes furos.

A todos os amigos que ainda estão ou que já passaram pelo LNCA (Rodrigo Almeida, Rodrigo Cabeção, Andréa, Liana, Juliano, Biológico, Amanda, Dimas, Sérgio, Cuasi, Oscar, Laudi, Tuka, Luciana, Ana, Elaine, Batata, André, etc), por formarem um grupo especial para se conviver e discutir ciência.

Ao Fillipe e ao Simão, pela amizade construída à base de muitas partidas de vôlei ao longo destes anos.

A todo o pessoal da Embrapa (CNPGL), em especial ao seu Hélio, ao Baiano, ao Del e ao Dr. Luiz Aroeira, que deram todo o suporte para o desenvolvimento do primeiro projeto.

À Agribrands por financiar grande parte do primeiro trabalho, à Nutron pela doação do óleo de peixe e à Coimbra, pela doação do farelo de soja.

À Fapesp, pela bolsa de estudos concedida. 


\section{SUMÁRIO}

\begin{tabular}{|c|c|}
\hline \multirow{2}{*}{ RESUMO } & Página \\
\hline & ix \\
\hline 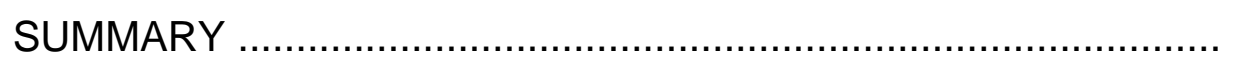 & xii \\
\hline 1 INTRODUÇÃO .... & 1 \\
\hline 2 REVISÃO DE LITERATURA & 3 \\
\hline 2.1 Ácido linoléico conjugado ........... & 3 \\
\hline 2.1.1 Biossíntese . & 3 \\
\hline 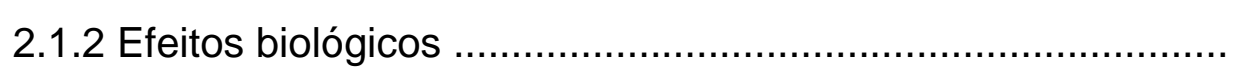 & 4 \\
\hline 2.1.3 Mecanismo de ação do CLA trans-10 cis-12 .. & 5 \\
\hline 2.2 Depressão da gordura do leite (DGL) . & 7 \\
\hline 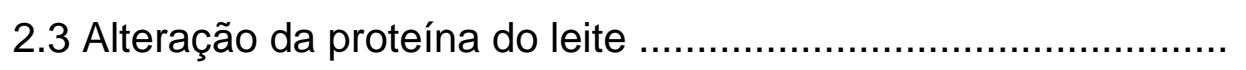 & 12 \\
\hline 3 DESEMPENHO E PERFIL DE ÁCIDOS GRAXOS DO LEITE & \\
\hline DE VACAS ALIMENTADAS COM DIETAS CONTENDO & \\
\hline ÁCIDO LINOLÉICO CONJUGADO E DOIS NÍVEIS DE & \\
\hline PROTEÍNA & 14 \\
\hline Resumo ................. & 14 \\
\hline 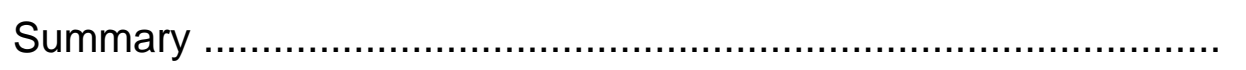 & 16 \\
\hline 3.1 Introdução ........ & 18 \\
\hline 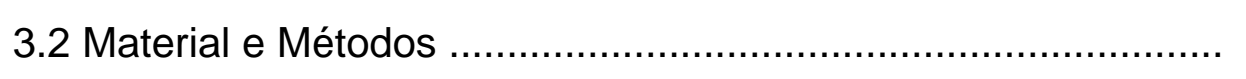 & 20 \\
\hline 3.2.1 Local, animais e instalações ......................... & 20 \\
\hline 3.2.3 Período experimental . & 25 \\
\hline
\end{tabular}


3.2.4 Medição da produção de leite e coleta de amostras

3.2.5 Avaliação do consumo, peso vivo e escore de condição corporal

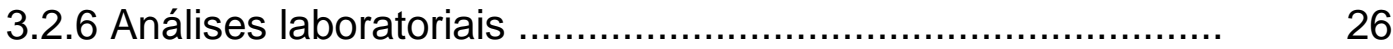

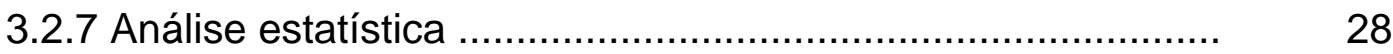

3.3 Resultados e Discussão ......................................................... 29

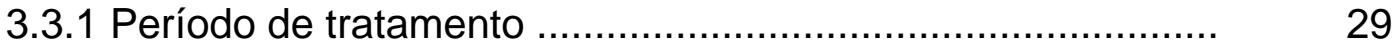

3.3.1.1 Desempenho e composição do leite .................................. 29

3.3.1.2 Perfil de ácidos graxos do leite .......................................

3.3.1.3 Parâmetros metabólicos ...............................................

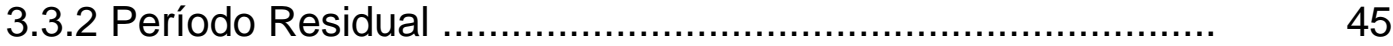

3.4 Conclusões ……......................................................... 50

4 VARIAÇÃO TEMPORAL DO PERFIL DE ÁCIDOS GRAXOS DOLEITE E SUA RELAÇÃO COM A DEPRESSÃO DE GORDURA DO LEITE (DGL) DE VACAS ALIMENTADAS COM DIETAS CONTENDO ÓLEO DE PEIXE E NÍVEIS DISTINTOS DE FIBRA …............................................ 51

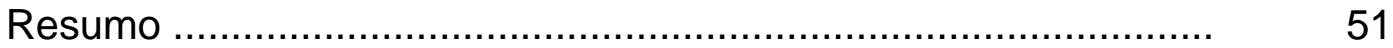

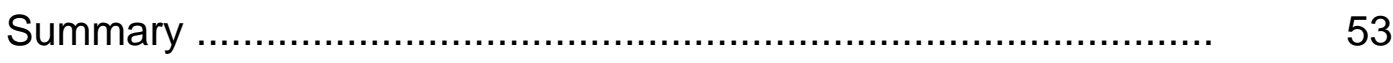

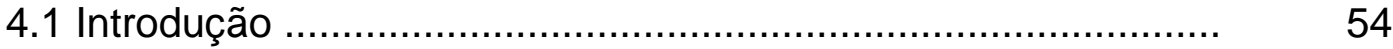

4.2 Material e Métodos .............................................................. 56

4.2.1 Animais, instalações e tratamentos .................................... 56

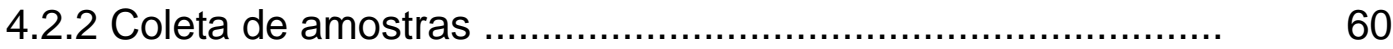

4.2.3 Avaliação do consumo, escore corporal (ECC), peso vivo e produção de leite .................................................................... 60

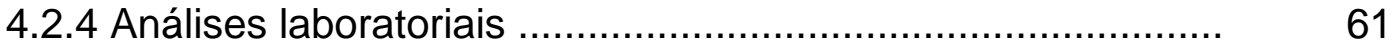

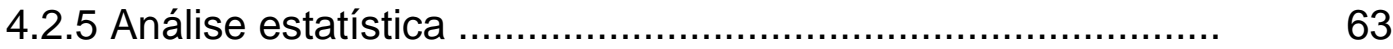

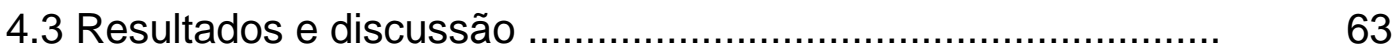

4.3.1 Desempenho, composição do leite e consumo de matéria 


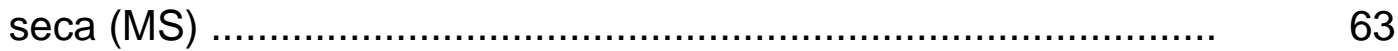

4.3.2 Perfil de ácidos graxos do leite ............................................. 81

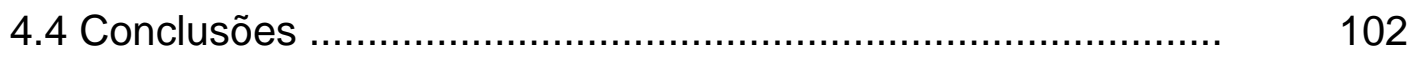

5 CONCLUSÕES GERAIS ...................................................... 105

REFERÊNCIAS BIBLIOGRÁFICAS ........................................ 107 


\title{
DESEMPENHO, COMPOSIÇÃO DO LEITE E MECANISMOS ENVOLVIDOS NA DEPRESSÃO DA GORDURA DO LEITE (DGL) DE VACAS RECEBENDO ÁCIDOS LINOLÉICOS CONJUGADOS (CLA) E ÓLEO DE PEIXE NA DIETA
}

\author{
Autor: MARCO ANTÔNIO SUNDFELD DA GAMA \\ Orientador: Prof. Dr. DANTE PAZZANESE DUARTE LANNA
}

\section{RESUMO}

A manipulação da dieta constitui uma prática efetiva e rápida de alteração da composição do leite, especialmente do seu teor de gordura. Entretanto, os mecanismos envolvidos não são ainda completamente conhecidos, embora muito se tenha avançado na última década. Sabe-se hoje que certo tipo de ácido graxo (CLA trans-10 cis-12) formado no rúmen sob condições específicas de alimentação é capaz de inibir a síntese de gordura do leite. Entretanto, depressão da gordura do leite (DGL) tem sido observada em casos (e.g. dietas contendo óleo de peixe) onde não há formação deste inibidor. Embora o efeito do CLA sobre a secreção de gordura do leite já esteja bem caracterizado, estudo prévio conduzido pelo nosso grupo mostrou ainda um 
aumento do teor de proteína do leite em resposta a este tratamento. Dois experimentos foram conduzidos com os seguintes objetivos principais, respectivamente: 1 ) determinar se um maior suprimento de proteína através da dieta afeta a secreção de proteína do leite de vacas recebendo CLA e 2) Estudar os mecanismos envolvidos na DGL de vacas recebendo dietas contendo óleo de peixe (OP) e níveis distintos de fibra. No primeiro experimento, 48 vacas em lactação receberam os seguintes tratamentos: 1) Dieta controle (DC) + Lac100, 2) DC + CLA, 3) Dieta com alta proteína (DAP) + Lac100 e 4) DAP + CLA. O Lac100 (sais de cálcio de óleo de soja) foi utilizado como placebo. O CLA foi protegido por encapsulação e o produto utilizado continha $\sim 16 \%$ de CLA. No segundo experimento, 12 vacas em lactação foram avaliadas em 3 períodos: a) Basal: os animais receberam uma dieta com alto teor de fibra sem OP (dieta basal) por 12 dias; b) Suplementação: 4 vacas/grupo receberam os seguintes tratamentos: 1) Dieta com alta fibra + OP $(A F+O P), 2)$ Dieta com baixa fibra sem OP (BF) e 3) Dieta com baixa fibra + OP $(\mathrm{BF}+\mathrm{OP})$; c) Pós-suplementação: todos os animais passaram a receber novamente a dieta basal por 12 dias. Os resultados obtidos no primeiro experimento mostraram que o CLA não foi eficientemente protegido, de forma que a redução da secreção de gordura do leite foi de pequena magnitude em relação a outros trabalhos. Da mesma forma, a proteção dos sais de cálcio de óleo de soja foi pequena, resultando em maior concentração de CLA cis-9 trans-11 $(P<0,05)$ e menor concentração de ácido linoléico $(P<0,05)$ no leite dos animais. Apesar da concentração do CLA trans-10 cis-12 no leite ter aumentado igualmente em resposta ao CLA e ao Lac100, o teor de gordura do leite foi menor $(P<0,05)$ no primeiro tratamento, sugerindo a presença de outros inibidores (ou precursores) no produto utilizado. A concentração de CLA trans10 cis-12 no leite explicou $\sim 50 \%$ da variação da DGL, sugerindo que outros fatores afetaram a síntese de gordura do leite. Os resultados do segundo experimento demostraram, de forma inédita, que o CLA trans-9 cis-11 e o C18:1 cis-11 estão estreitamente relacionados à DGL dos animais que receberam OP. 
A DGL foi causada por uma ampla redução $(P<0,01)$ da secreção tanto dos ácidos graxos sintetizados de novo quanto dos pré-formados, sugerindo que o mecanismo da DGL pode envolver a inibição de diferentes enzimas lipogênicas. O menor $(P<0,01)$ índice de atividade da enzima $\Delta-9$ dessaturase em animais que receberam OP é consistente com a idéia acima. Diferentemente do observado em resposta ao OP, a secreção de gordura do leite não foi afetada pelo tratamento $B F(P>0,1)$. Os teores de proteína e lactose aumentaram na dieta BF e nas dietas contendo OP, respectivamente. 


\title{
PERFORMANCE, MILK COMPOSITION AND MECHANISMS INVOLVED IN MILK FAT DEPRESSION (MFD) OF COWS FED DIETS WITH CONJUGATED LINOLEIC ACID (CLA) AND FISH OIL
}

\author{
Author: MARCO ANTÔNIO SUNDFELD DA GAMA \\ Adviser: Prof. Dr. DANTE PAZZANESE DUARTE LANNA
}

\section{SUMMARY}

Diet manipulation is an effective and rapid way to change milk composition, mainly for fat content. However, mechanisms are not fully undestood in despite of progress in the area over the last decade. Nowadays, it is known that a molecule of fatty acid (CLA trans-10 cis-12) which is formed in the rumen under specific feeding situations is capable of inhibiting milk fat synthesis. However, milk fat depression (MFD) has been observed even at conditions where there is no formation of trans-10 cis12 CLA (e.g. fish oilsupplemented diets). Although CLA effects on milk fat synthesis are wellestablished, previous study from our group also showed an increase on milk protein content in cows fed CLA. Two trials were conducted with two main objectives: 1) to determine if an additional supply of diet protein affects milk fat synthesis in cows fed CLA and 2) to study the mechanisms involved in MFD of 
cows fed diets with fish oil (FO) and different fiber levels. In the first trial, 48 lactating cows received the treatments as follow: 1) Control Diet (CD) + Lac100, 2) $C D+C L A, 3)$ High Protein Diet (HPD) + Lac100 and 4) HPD + CLA. The Lac100 (calcium salts of soybean oil) was used as a placebo. CLA was protected by encapsulation (prills) and the product contained 16\% CLA. In the second trial, 12 lactating dairy cows were evaluated in three periods: a) Basal: for 12 days, all cows received a baseline diet (High fiber without FO); b) Suplementation: 4 cows/group received the treatments for 21 days: 1) High fiber diet + FO (HF+FO); 2) Low fiber diet without FO (LF) and 3) Low fiber diet + FO (LF+FO); c) Post-supplementation: cows returned to baseline diet on 12 days. Results from the first trial showed that CLA protection method was innefficient. Thus, milk fat reduction was smaller than in other studies. Protection of calcium salts of soybean oil was also small which resulted in higher cis-9 trans-11 CLA and lower linoleic acid concentrations $(P<0.05)$ in milk from cows fed Lac100. In despite of similar milk trans-10 cis-12 CLA increase in response to CLA and Lac100, milk fat content was lower $(P<0.05)$ in cows fed CLA. It suggests the presence of other fat inhibitors (or precursors) in the product containing CLA isomers. Moreover, concentration of milk trans-10 cis-12 CLA explained $\sim 50 \%$ of MFD suggesting others factors influencing milk fat synthesis. Results of the second trial were inedit in showing the close association of milk trans-9 cis-11 CLA and C18:1cis-11 concentrations and FO-induced MFD. MFD resulted from a lower $(P<0,01)$ secretion of both de novo and preformed milk fatty acids. It suggests that mechanisms of FO-induced MFD must involve the inhibition of different lipogenic enzymes. The lower $(P<0.01)$ dessaturase activity index in cows fed FO is consistent with this hypothesis. In contrast to FO, milk fat secretion was unchanged $(P>0.1)$ by LF diet which is consistent with low CLA trans-10 cis-12 and C18:1trans-10 concentrations in milk from cows fed this diet. Contents of milk protein and milk lactose increased $(P<0.05)$ in cows fed $L F$ and FO diets, respectivelly. 


\section{INTRODUÇÃo}

A influência da nutrição sobre a composição do leite, particularmente quanto ao seu teor de gordura, já é conhecida há algum tempo. O fornecimento de determinados tipos de dieta para vacas em lactação tem resultado na queda do teor e da secreção de gordura do leite, e esta situação é geralmente referida como depressão da gordura do leite (DGL).

Várias teorias foram propostas nas últimas décadas para explicar a DGL, sendo os supostos mecanismos baseados em alterações no metabolismo ruminal e dos tecidos. Uma destas teorias, a dos ácidos graxos "trans", foi proposta inicialmente em 1970, mas suas bases biológicas têm sido melhor compreendidas nos últimos anos. Atualmente, sabe-se que a DGL está associada à formação de intermediários específicos da biohidrogenação ruminal dos ácidos graxos poliinsaturados presentes na dieta, os quais são potentes inibidores da síntese de gordura na glândula mamária. Como exemplo temos o CLA trans-10 cis-12, cuja concentração aumenta consideravelmente no leite de vacas com DGL recebendo dietas contendo baixo teor de fibra suplementadas com lipídios de origem vegetal.

Entretanto, dietas suplementadas com óleo de peixe têm resultado em DGL mesmo quando não há formação do CLA trans-10 cis-12. Além disso, tal resposta tem sido observada mesmo quando os níveis de fibra da dieta são adequados. Estas observações têm levado à especulação de que outros ácidos graxos, além do CLA trans-10 cis-12, poderiam inibir a síntese de gordura do leite em vacas recebendo óleo de peixe na dieta. Um dos experimentos realizados pelo nosso grupo, cujos resultados são apresentados no segundo 
artigo desta tese, teve como objetivo principal determinar os possíveis mecanismos envolvidos na DGL de vacas recebendo dietas com OP e níveis distintos de fibra.

Além do efeito sobre a secreção de gordura do leite, estudo prévio conduzido pelo nosso grupo mostrou um aumento do teor e da secreção de proteína do leite em vacas a pasto suplementadas com CLA protegido como sais de cálcio. Entretanto, neste estudo, a dieta foi formulada para fornecer um excesso de proteína metabolizável em relação às exigências dos animais, de forma esta condição pode ter sido determinante para a obtenção de tal resposta. Um segundo experimento teve como objetivo principal avaliar a importância de um maior aporte de proteína dietética sobre a secreção de proteína do leite de vacas recebendo CLA. 


\section{REVISÃO DE LITERATURA}

\section{1 Ácido Linoléico Conjugado}

\subsubsection{Biossíntese}

Genericamente referidos como CLA, os ácidos linoléicos conjugados compreendem, na verdade, uma série de isômeros de posição e geométricos do ácido linoléico, que se caracterizam por apresentar duplas ligações conjugadas. Estes compostos encontram-se em níveis mais elevados nos produtos de ruminantes (Chin et al., 1992), devido à incompleta biohidrogenação ruminal dos ácidos graxos insaturados presentes na dieta (Bauman et al., 1999).

Embora mais de dez isômeros já tenham sido identificados na gordura do leite (Sehat et al., 1998) e da carne (Fritsche et al., 2000), o CLA cis-9 trans-11 e o CLA trans-7 cis-9 têm sido os encontrados em maiores concentrações, geralmente compreendendo 75 a 80\% do CLA total (Yarawecz et al., 1998). A maior parte destes dois isômeros é sintetizada endogenamente por ação da enzima $\Delta-9$ dessaturase presente na glândula mamária, tendo como substrato os ácidos graxos C18:1 trans-11 e C18:1 trans-7 formados durante o processo de biohidrogenação ruminal dos ácidos graxos poliinsaturados presentes na dieta (Griinari et al., 2000; Corl et al., 2002). 
Por outro lado, os outros isômeros de CLA presentes na gordura do leite e da carne dos ruminantes parecem ser formados exclusivamente no rúmen (Bauman et al., 2003). O CLA trans-10 cis-12 é um exemplo deste caso, sendo que sua concentração na gordura do leite aumenta consideravelmente em vacas alimentadas com dietas contendo baixo teor de fibra suplementadas com lipídios de origem vegetal (Bauman \& Griinari, 2001).

\subsubsection{Efeitos biológicos}

Estudos com modelos animais têm demonstrado que o CLA apresenta inúmeros efeitos benéficos à saúde, tais como a inibição do crescimento de tumores, efeito anti-aterogênico, redução na deposição/secreção de gordura, restauração da sensibilidade à insulina e modulação da resposta imunológica (Pariza et al., 2001). Até onde se sabe, os pronunciados efeitos biológicos relacionados a estes compostos parecem ser resultado da ação de dois isômeros principais: o cis-9 trans-11 e o trans-10 cis-12. O CLA cis-9 trans-11 tem se mostrado um potente anti-carcinogênico em estudos com animais e em culturas de tecidos de humanos (Parodi, 1997), além de reduzir efeitos catabólicos provocados pela resposta imunológica (Cook \& Pariza, 1998). Por outro lado, o efeito do CLA trans-10 cis-12 está relacionado principalmente à alteração do metabolismo de lipídios (Pariza et al., 2001).

Piperova et al. (2000) demostraram que a redução da secreção de gordura do leite observada em vacas alimentados com determinados tipos de dieta (e.g. dietas com baixo teor de fibra) estava associada ao aumento da concentração de CLA trans-10 cis-12 no leite. Neste mesmo período, estudos de curta duração com vacas em lactação (Loor \& Herbein, 1998; Chouinard et al., 1999) mostraram que a infusão abomasal de suplementos de CLA contendo diferentes isômeros resultou em ampla redução na secreção da gordura do leite. Esta resposta também foi observada em estudos de longa duração, onde 
estes suplementos foram protegidos da ação ruminal pela formação de sais de cálcio e, então, fornecidos na dieta dos animais (Giesy et al., 1999; Medeiros et al., 2000; Bernal-Santos et al., 2001; Giesy et al., 2002; Pefield et al., 2002).

Todos os experimentos acima utilizaram suplementos de CLA que continham diversos isômeros, dentre os quais o trans- 8 cis-10, o cis- 9 trans- 11 , o trans-10 cis-12 e o cis-11 trans-13.

A identificação do CLA trans-10 cis-12 como o responsável pela redução da secreção de gordura do leite foi feita por Baumgard et al. (2000), através da infusão abomasal de isômeros purificados do CLA trans-10 cis-12 e do CLA cis9 trans-11. Estudo recente (Perfield et al., 2004) avaliou ainda efeitos do CLA trans-8 cis-10 e do CLA cis-11 trans-13 sobre a síntese de gordura do leite, mas nenhuma inibição foi observada. O potente efeito inibitório do CLA trans-10 cis12 sobre a síntese de gordura do leite foi confirmado posteriormente em estudos de dose-resposta conduzidos por Baumgard et al. (2001) e Peterson et al. (2002). Mesmo quando quantidades pequenas deste isômero (2,5 g/dia) foram infundidas no abomaso de vacas em lactação (Peterson et al., 2002), reduções significativas (cerda de 17\%) no teor e na produção de gordura do leite foram observadas.

\subsubsection{Mecanismo de ação do CLA trans-10 cis-12}

A redução da secreção de gordura do leite em resposta ao fornecimento do CLA trans-10 cis-12 pode ser explicada, pelo menos em parte, pela inibição da atividade das enzimas lipogênicas acetil-CoA carboxilase e ácido graxo sintetase (Piperova et al., 2000; Hayashi et al., 2002). Estas enzimas são responsáveis pela síntese de novo de lipídios na glândula mamária, que determina a formação dos ácidos graxos de cadeias curta e média (de 4 a 16 carbonos) secretados no leite. 
Consistente com este mecanismo de ação, reduções significativas da concentração destes ácidos graxos no leite foram encontradas em vacas recebendo suplementos de CLA contendo este isômero (Loor \& Herbein, 1998; Chouinard et al., 1999). Entretanto, estes estudos mostraram também que a redução da secreção de gordura pelo CLA trans-10 cis-12 estava associada também a uma menor secreção de ácidos graxos de cadeia longa, os quais são provenientes da dieta ou da mobilização das reservas de gordura corporal. Todavia, a magnitude desta redução é menor do que a observada para os ácidos graxos sintetizados de novo quando altas doses de CLA trans-10 cis-12 são infundidas (Baumgard et al., 2001 e Peterson et al., 2002), justificando a menor concentração dos ácidos graxos de cadeias curta e média observadas em alguns estudos.

Recentemente, Baumgard et al. (2002) determinaram a abundância de RNA mensageiro (RNAm) de várias enzimas lipogênicas em biópsias de tecido mamário obtidas de vacas tratadas com o CLA trans-10 cis-12. Estes autores observaram reduções na quantidade de RNAm de genes que codificam enzimas envolvidas na captação de ácidos graxos pré-formados da circulação (e.g. lipase lipoprotéica), síntese de novo de ácidos graxos (e.g. acetil-CoA carboxilase e ácido graxo sintetase), dessaturação de ácidos graxos (e.g. $\Delta-9$ dessaturase) e síntese de triglicerídios (e.g. glicerol-P acil-transferase).

Portanto, parece que o efeito inibitório do CLA trans-10 cis-12 sobre a secreção de gordura do leite envolve a coordenação de inúmeros eventos relacionados à síntese de lipídios na glândula mamária. Isto constitui um exemplo claro de como um único nutriente pode afetar profundamente o metabolismo. 


\subsection{Depressão da Gordura do Leite (DGL)}

O fornecimento de determinados tipos de dieta causa grande redução no teor e na secreção de gordura do leite, e esta situação é geralmente referida como depressão da gordura do leite (DGL). Estas dietas apresentam normalmente grande quantidade de concentrados, forragens finamente picadas e lipídios insaturados (Sutton, 1989; Van Soest, 1994). Três principais teorias foram propostas para explicar a DGL como consequência das alterações dietéticas relacionadas acima. Embora todas sejam baseadas em alterações no metabolismo ruminal, duas delas relacionam a DGL à limitação de substratos lipogênicos para a glândula mamária, enquanto que a outra sugere uma inibição direta da síntese de lipídios por certos ácidos graxos formados no rúmen. Um destes ácidos graxos é o CLA trans-10 cis-12, cujo efeito sobre a síntese de lipídios já foi apresentado anteriormente. Entretanto, uma discussão mais detalhada sobre a evolução desta teoria será apresentada neste item.

A primeira teoria sugeria que a DGL ocorria por uma redução da produção ruminal de ácido acético em dietas com alto teor de grãos. Esta suposição era baseada na redução da relação acetato/propionato no rúmen, freqüentemente observada nesta situação (Tyznick \& Allen, 1951; Sutton, 1985). Entretanto, estudos que estimaram a produção dos ácidos graxos voláteis mostraram que a redução nesta relação era conseqüência de um aumento na produção de propionato, já que a produção de acetato não era afetada (Bauman et al., 1971).

A segunda teoria, denominada insulino-glicogênica, foi proposta inicialmente por McClymont \& Vallance (1962), e considera o aumento da concentração plasmática de insulina como o fator responsável pela depressão da gordura do leite. Segundo esta teoria, o aumento da produção de ácido propiônico em dietas com alto teor de grãos promoveria um aumento da glicemia através da gliconeogênese, que por sua vez resultaria em maior secreção de insulina pelo pâncreas. Como conseqüência, haveria uma 
diminuição da lipólise ou aumento da lipogênese no tecido adiposo (Bauman, 2000), diminuindo o aporte de precursores para a síntese de lipídios na glândula mamária. Para testar esta teoria, McGuire et al. (1995) conduziram um experimento onde vacas em final de lactação foram submetidas a uma concentração plasmática de insulina 4 a 5 vezes superior aos níveis basais, mantendo-se a glicemia dentro dos níveis normais através de infusão intravenosa de glicose. Estes autores observaram mínima redução na secreção de gordura do leite, o que colocou em dúvida a validade da teoria insulinoglicogênica. Em contrapartida, Lemosquet et al. (1997) e Hurtaud et al. (1998) observaram uma diminuição significativa no teor de gordura do leite quando infundiram glicose no duodeno de vacas em lactação. Esta resposta foi associada a reduções na concentração de ácidos graxos de cadeia longa no plasma (ácidos graxos não-esterificados) e no leite dos animais. Estes autores atribuíram este efeito a uma diminuição da lipólise promovida pela ação da insulina, embora Hurtaud et al. (1998) não tenham observado aumento da concentração de insulina do plasma. Entretanto, é importante destacar que estes autores realizaram apenas uma coleta de sangue imediatamente antes do fornecimento da ração, enquanto que várias coletas foram feitas durante um período de três horas após a alimentação da manhã no experimento de Lemosquet et al. (1997). Isto mostra que o regime de coleta de sangue pode ser determinante para que sejam detectados aumentos na concentração plasmática de insulina, uma vez que sua concentração varia entre as refeições.

Recentemente, Bauman \& Griinari (2003) encontraram cerca de 35\% de redução na secreção de gordura do leite quando infundiram insulina em vacas no início da lactação, utilizando a mesma técnica de McGuire et al. (1995). Neste último experimento, à semelhança dos realizados por Lemosquet et al. (1997) e Hurtaud et al. (1998), uma redução da concentração plasmática de ácidos graxos não-esterificados foi observada.

Em suma, os resultados apresentados anteriormente indicam que o efeito inibitório da insulina sobre a secreção de gordura do leite é causado por 
uma redução no aporte de ácidos graxos pré-formados oriundos da lipólise, de forma que maiores respostas são esperadas quando as vacas encontram-se no início da lactação.

A última teoria para explicar a DGL propõe uma inibição direta da síntese de gordura na glândula mamária por ação de ácidos graxos "trans" formados no rúmen pela incompleta biohidrogenação dos ácidos graxos poliinsaturados presentes na dieta (Davis \& Brown, 1970). Diversos trabalhos conduzidos na última década parecem sustentar esta teoria.

Gaynor et al. (1994) estudaram o efeito da infusão abomasal de uma mistura de ácidos graxos de configuração "cis" ou "trans" sobre a produção e composição do leite de vacas em lactação. Os resultados mostraram que os ácidos graxos "trans" reduziram o percentual de gordura mais do que os ácidos graxos de configuração "cis" ( $25 \%$ e $5 \%$ de redução, respectivamente). A produção de leite não foi alterada pelos tratamentos, o que resultou também em menor produção de gordura nos animais infundidos com os ácidos graxos "trans".

Em trabalho subseqüente, Gaynor et al. (1995) estudaram o efeito do fornecimento de dietas com 40 ou $80 \%$ de concentrado (na base da MS) sobre parâmetros produtivos e metabólicos de vacas em lactação. Estes autores encontraram redução do teor e da produção de gordura do leite em resposta à dieta de alto concentrado. Esta redução foi associada com uma maior concentração de glicose, ácidos graxos não-esterificados e insulina no plasma, consistente com a teoria insulino-glicogênica. Além disso, estes autores observaram uma correlação negativa entre a concentração de ácidos graxos trans-C18:1 no leite e a concentração de gordura no leite. Neste experimento, as vacas que apresentaram queda de mais de uma unidade percentual na gordura do leite foram classificadas como responsivas e as restantes foram consideradas não-responsivas. Quando separadas nestes dois grupos, foi observada uma interação significativa entre grupo e o nível de fibra da dieta para o teor de ácidos graxos C18:1 "trans" do leite, com o grupo das vacas 
responsivas apresentando maiores aumentos na concentração destes ácidos graxos em relação ao grupo das vacas não-responsivas. Esta observação levou os autores a considerarem o aumento dos ácidos graxos "trans" como a principal causa da depressão da gordura do leite.

Posteriormente, Griinari et al. (1998) testaram a hipótese de que duas condições são necessárias para a produção de ácidos graxos "trans" no rúmen e a ocorrência de depressão da gordura do leite: 1) a presença de substrato ruminal na forma de ácidos graxos insaturados e 2) um ambiente ruminal modificado, o qual leva à incompleta biohidrogenação destes ácidos graxos. Para tal, fizeram um experimento fatorial associando dietas de alto ou baixo teor de fibra com fontes de lipídios saturados ou insaturados. A quantidade de fibra na dieta e o tipo de lipídio tiveram efeitos significativos sobre o teor e a produção de gordura do leite, mas os efeitos foram mais pronunciados da dieta de baixa fibra associada com lipídios insaturados. Nesta dieta, o teor e a produção de gordura do leite foram 30 e 35\% menores, respectivamente, do que na dieta de alta fibra adicionada de lipídios saturados. O fornecimento de lipídios insaturados aumentou a concentração de ácidos graxos C18:1 trans na gordura do leite, mas este efeito não foi observado em resposta à redução do nível de fibra da dieta. O grande avanço deste trabalho em relação aos anteriores foi o reconhecimento de que a maior depressão da gordura em resposta à dieta com baixo teor de fibra adicionada de lipídios insaturados estava associada, especificamente, ao aumento do ácido graxo C18:1 trans-10.

Esta observação foi confirmada em estudos posteriores, onde a DGL foi também relacionada a um aumento da concentração do CLA trans-10 cis-12 na gordura do leite (Piperova et al., 2000; Offer et al., 2001). Como já mencionado anteriormente, experimentos subseqüentes comprovaram a potente ação inibitória deste CLA sobre a síntese de gordura do leite (Baumgard et al., 2000; Baumgard et al., 2001; Peterson et al., 2002).

Ao contrário do que se observa quando da suplementação da dieta com lipídios de origem vegetal, reduções significativas do teor e da secreção da 
gordura do leite têm sido observadas em resposta à inclusão de óleo de peixe na dieta mesmo quando esta apresenta níveis adequados de fibra (Chilliard et al., 1999; Offer et al., 1999; Arola et al., 2002). Além disso, a DGL observada neste caso está geralmente associada a aumentos no teor do ácido graxo C18:1 trans-10, mas não do CLA trans-10 cis-12 (Griinari et al., 2000; Offer et al., 2001).

Obviamente, a diferente composição dos ácidos graxos presentes nos óleos vegetais e marinhos devem ser considerados ao se estudar os mecanismos envolvidos na DGL, em ambos os casos. Os óleos de peixe são ricos em ácidos graxos poliinsaturados de cadeia longa, dos quais 0 eicosapentaenóico (EPA, C20:5 n-3) e o docosahexaenóico (DHA, C22:6 n-3) são os mais importantes (Givens et al., 2000). Embora estes compostos possam inibir diretamente a síntese de lipídios na glândula mamária, como mostrado nos experimentos com infusão pós-ruminal do óleo (Chilliard et al., 1999), as maiores respostas têm sido observadas quando este é fornecido na dieta (Chilliard et al., 2001). Isto sugere que a DGL em vacas tratadas com óleo de peixe envolve efeitos sobre o metabolismo ruminal.

A baixa eficiência de transferência do EPA e do DHA da dieta para o leite (Chilliard et al., 2001) é, em grande parte, explicada pela ampla biohidrogenação destes compostos no rúmen, conforme mostrado em estudo de incubação in vitro (Gulati et al., 1999). Isto sugere que, provavelmente, os intermediários da biohidrogenação do EPA e do DHA podem estar relacionados à DGL. Entretanto, ao contrário dos experimentos realizados com o CLA trans10 cis-12, esta hipótese nunca foi testada diretamente.

Como os teores dos ácidos graxos C18:1 trans-10 e C18:1 trans-11 aumentam significativamente no leite de vacas alimentadas com dietas contendo óleo de peixe (Griinari et al., 2000; Offer et al., 2001), tem-se sugerido que o EPA e o DHA, ou os intermediários de sua biohidrogenação, afetam a última etapa de biohidrogenação dos ácidos graxos poliinsaturados de 18 carbonos (linoléico e $\alpha$-linolênico) presentes na dieta basal. O aumento da 
concentração de C18:1 trans-10 no leite poderia, supostamente, estar envolvido na DGL observada nestes casos, visto que sua concentração também aumenta em vacas com típica DGL (dietas com baixo teor de fibra suplementadas com lipídios de origem vegetal).

\subsection{Alteração da Proteína do Leite}

A compreensão dos mecanismos envolvidos na síntese de proteína do leite e a possibilidade de manipulação deste componente são de especial interesse, uma vez que seu valor tem aumentado tanto no aspecto econômico quanto nutricional (Mackle \& Bauman, 1998). Grande parte das pesquisas neste sentido têm focado o efeito do suprimento de aminoácidos sobre esta variável.

Rulquin et al. (1995) revisou 121 estudos onde foram avaliados os efeitos do suprimento de metionina e lisina (infundidos no abomaso ou protegidos) sobre a produção e concentração da proteína do leite, e encontraram somente respostas médias modestas a estes tratamentos $(29 \mathrm{~g} / \mathrm{d}$ e $1,1 \mathrm{~g} / \mathrm{kg}$, respectivamente). Nos estudos onde foram avaliados os efeitos da infusão pósruminal de caseína, a secreção de proteína do leite aumentou em média 91 g/dia (Mackle \& Bauman, 1998). Estes autores não observaram correlação entre a magnitude das respostas observadas e a quantidade de caseína infundida, e as maiores respostas foram observadas quando o suprimento de aminoácidos da dieta era inadequado. Este padrão de resposta também foi observado em estudos onde aminoácidos foram infundidos intravenosamente (Metcalf et al., 1996).

Estes resultados indicam que o simples fornecimento de aminoácidos para vacas recebendo adequada nutrição não garante aumentos na produção de proteína do leite. Por outro lado, resultados obtidos por Griinari et al. (1997) e Mackle et al. (1998) indicam que a manipulação do sistema endócrino pode 
promover aumentos significativos na produção de proteína do leite, mesmo em vacas alimentadas com dietas com níveis adequados de energia e proteína.

Nestes experimentos, os animais foram submetidos a uma concentração de insulina plasmática 4 a 5 vezes superior à concentração normal, mantendose a glicemia dentro dos valores normais por infusão de glicose. O tratamento com insulina promoveu, em ambos os trabalhos, aumentos significativos no teor e na produção de proteína do leite (cerca de 8 e 18\%, respectivamente). Com base nestes resultados, estes autores sugeriram que a insulina desempenha um papel importante na regulação da síntese de proteína do leite, seja direta ou indiretamente.

Consistente com esta hipótese, Medeiros et al. (2000) observaram aumentos significativos no teor e na produção de proteína do leite de vacas a pasto suplementadas com $150 \mathrm{~g} /$ dia de CLA protegido na forma de sais de cálcio. Como a produção de leite é normalmente limitada pela baixa ingestão de energia em vacas a pasto, a redução da secreção de energia no leite (conseqüência da redução do teor de gordura do leite pela ação do CLA trans10 cis-12) pôde ter permitido aos animais secretar maior quantidade de proteína. Entretanto, é importante destacar que os animais deste experimento receberam uma dieta com teor de proteína superior às suas exigências, de forma que isto pôde também ter contribuído para a resposta observada. Um dos objetivos do trabalho apresentado a seguir foi exatamente avaliar a importância deste suprimento adicional de proteína. 


\section{DESEMPENHO E PERFIL DE ÁCIDOS GRAXOS DO LEITE DE VACAS ALIMENTADAS COM DIETAS CONTENDO ÁCIDO LINOLÉICO CONJUGADO (CLA) E DOIS NÍVEIS DE PROTEÍNA}

\section{Resumo}

O presente experimento foi conduzido com o objetivo de avaliar a importância do nível de proteína da dieta sobre as respostas de vacas recebendo CLA protegido, especialmente com relação ao aumento de secreção de proteína do leite observado em estudo prévio realizado pelo nosso grupo. Para tal, 48 vacas em início de lactação ( $30 \pm 5$ d) foram blocadas pela produção de leite e número de lactações no início do experimento. Um arranjo fatorial do tipo 2x2 (dois níveis de proteína na dieta e suplementação com duas fontes de lipidios) foi empregado para avaliar os efeitos dos tratamentos, os quais foram: 1) Dieta Controle (DC) + Lac100, 2) DC + CLA, 3) Dieta com alta proteína (DAP) + Lac100 e d) DAP + CLA. As dietas controle e com alta proteína foram formuladas para suprir 100 a 115\% das exigências de proteína metabolizável estimadas pelo CNCPS, respectivamente. O produto contendo CLA protegido por encapsulação foi fornecido pela Agribrands e continha cerca de 16\% de isômeros do CLA. O Lac100 ${ }^{\circledR}$ são sais de cálcio de óleo de soja fabricados pela Yakult e foram utilizados como placebo neste estudo. Cada animal recebeu $400 \mathrm{~g} / \mathrm{dia}$ dos suplementos lipídicos. O experimento foi dividido 
em 3 períodos: 1) Pré-tratamento (1 $\stackrel{\text { os }}{ } 30$ dias de lactação): adaptação ao Calan Gates e formação do blocos, 2) Tratamento (dos 30 aos 72 dias de lactação): fornecimento dos tratamentos propriamente ditos e 3) Residual (dos 72 aos 79 dias de lactação): interrupção do fornecimento do CLA e substituição pelo Lac100. O teor de gordura do leite dos animais foi progressivamente reduzido após o início do fornecimento de ambos os suplementos (CLA e Lac100). Como a queda foi mais pronunciada nos animais tratados com CLA, um menor teor de gordura do leite $(P<0,05)$ foi observado neste grupo durante o período de tratamento. Entretanto, em virtude da baixa magnitude da redução do teor de gordura do leite $(\sim 10 \%)$, a produção de gordura foi inalterada $(P>0,1)$ em resposta ao CLA. Contrariamente ao observado com o teor de gordura do leite, a concentração de CLA trans-10 cis-12 aumentou após o início da suplementação lipídica (Efeito de tempo, $\mathrm{P}<0,05$ ), independentemente do nível de proteína da dieta. Paralelamente, uma redução da concentração de ácidos graxos de cadeias curta e média e um aumento dos de cadeia longa foi observada no leite dos animais que receberam tanto CLA quanto Lac100. A concentração de CLA trans-10 cis-12 no leite foi negativamente associada ao seu teor de gordura nos animais que receberam CLA ou Lac100, mas o teor de gordura do leite foi 0,3 unidades percentuais menor $(2,5 \times 2,2 \%)$ nas vacas tratadas com CLA, a uma mesma concentração de CLA trans-10 cis-12. Ao contrário do que se previa, as vacas que receberam Lac100 apresentaram maior $(P<0,05)$ concentração de CLA cis-9 trans-11 e menor $(P<0,05)$ concentração de ácido linoléico no leite do que aquelas que receberam CLA. O teor de gordura e o perfil de ácidos graxos do leite não diferiram $(P>0,1)$ entre os tratamentos CLA e Lac100 no período residual. Conforme esperado, o teor de uréia no leite aumentou $(P<0,01)$ em resposta ao fornecimento da dieta com alta proteína (DAP). Em geral, os resultados obtidos no presente experimento indicam que a proteção do CLA por encapsulação foi ineficiente e que os sais de cálcio de óleo de soja (Lac100) foram dissociados no rúmen. Como conseqüência, o efeito do CLA sobre a síntese de proteína do leite e a 
importância de um suprimento adicional de proteína na dieta sobre esta resposta não puderam ser apropriadamente avaliados. A concentração de CLA trans-10 cis-12 no leite explicou somente uma parte (cerca de 50\%) da variação da DGL, sugerindo que outros fatores afetaram a síntese de gordura do leite.

\section{PERFORMANCE AND MILK FATTY ACIDS PROFILE OF LACTATING DAIRY COWS FED DIETS WITH CONJUGATED LINOLEIC ACID (CLA) AND TWO PROTEIN LEVELS}

\section{Summary}

Previous research has shown an increase in milk protein content after treatment with conjugated linoleic acid (CLA). This study was conducted to evaluate the use of CLA prills (CLA protected by encapsulation) and the role of diet protein level on responses to protected CLA. Forty-eight cross-bred cows in early lactation were blocked by milk production and parity at the beginning of the study. A 2x2 factorial arrangement (two diet protein levels and CLA or placebo supplementation) was used to evaluate the treatments effects which were: a) Control diet (CD) + Lac100, b) CD + CLA prills, c) High protein diet (HPD) + Lac100 and d) HPD + CLA prills. The CD and HPD were formulated to supply 100 and $115 \%$ of the metabolizable protein requirements estimated by CNCPS, respectively. The CLA prills (Agribrands Inc., Canada) contained 16\% of CLA. The Lac100 is calcium salts of soybean oil (Yakult, Brazil) and was used as a placebo. Both supplement were fed at $400 \mathrm{~g} / \mathrm{animal} / \mathrm{day}$. The trial was divided in three periods: 1) Pre-treatment (from parturition to day 30 of lactation): adaptation to eletronic gates and evaluation of milk production and other parameters to block cows and to obtain baseline values; 2) Treatment period 
(from day 30 to 72 of lactation): animals received CLA or Lac100; and 3) Residual period (from day 72 to 79 of lactation): residual effects of CLA were evaluated. During this last period, CLA was replaced for Lac100, but different diet protein levels were maintained. The milk fat content was progressively reduced after the beginning of both CLA and Lac100 treatments. However, the drop was more pronounced in CLA treated cows which resulted in lower milk fat content $(P<0.05)$. The magnitude of this reduction was low $(-10 \%)$ and milk fat yield was unchanged $(P>0.1)$ in response to CLA. Opposite to changes in milk fat content, concentration of milk trans-10 cis-12 CLA increased after the beginning of lipids supplementation (Time Effect, $\mathrm{P}<0.05$ ), regardless of dietary protein level. Short and medium chain fatty acids decreased and long chain fatty acids increased in milk fat from cows receiving Lac100 or CLA. Concentration of milk trans-10 cis-12 CLA was negatively associated to milk fat content in cows receiving either CLA or Lac100, but milk fat content was 0.3 units lower (2.5 x $2.2 \%)$ in CLA treated cows at the same milk trans-10 cis-12 CLA concentration. Surprisingly, cows receiving Lac100 had more cis-9 trans-11 CLA and less linoleic acid $(P<0.05)$ in milk fat than CLA treated cows. Milk fat content and milk fatty acid profile did not differ $(P>0.1)$ between treatments in the residual period. As expected, milk urea content increased $(P<0.01)$ in cows receiving high protein. Results from the present study suggest the encapsulation method was inefficient in protecting the CLA in the rumen and the calcium salts of soybean oil (Lac100) were dissociated in the rumen. As a consequence, despite a significant inhibition of milk fat synthesis, the CLA effect on milk protein synthesis and the importance of additional diet protein could not be properly evaluated. Milk trans-10 cis-12 CLA concentration explained only a portion (about 50\%) of the MFD. It suggests other factors influencing milk fat synthesis. 


\subsection{Introdução}

Embora genericamente referidos como CLA, os ácidos linoléicos conjugados compreendem uma série de isômeros de posição e geométricos do ácido linoléico, que caracterizam-se por apresentar duplas ligações conjugadas. Estes compostos são encontrados normalmente em níveis mais elevados nos produtos de ruminantes ( 3 a $7 \mathrm{mg} / \mathrm{g}$ de gordura do leite e da carne), devido à incompleta biohidrogenação ruminal dos ácidos graxos insaturados presentes na dieta destes animais (Bauman et al., 1999).

Estudos com modelos animais têm demonstrado que o CLA apresenta inúmeros efeitos potencialmente benéficos à saúde, tais como a inibição do crescimento de tumores, efeito anti-aterogênico, redução na deposição/secreção de gordura, restauração da sensibilidade à insulina e modulação da resposta imunológica (Pariza et al., 2001). Embora possam existir inúmeras configurações do CLA, os pronunciados efeitos biológicos relacionados a estes compostos parecem ser resultado da ação de dois isômeros principais: o cis-9 trans-11 e o trans-10 cis-12. O CLA cis-9 trans-11 tem se mostrado um potente anti-carcinogênico em estudos com animais e em culturas de tecidos de humanos (Parodi, 1997), além de reduzir efeitos catabólicos presentes em certas respostas imunológicas (Cook et al, 1993). Este último efeito poderia explicar o aumento na deposição muscular durante o crescimento observado em alguns estudos (Ostrowska et al., 1999; Park et al., 1997).

Por outro lado, a infusão abomasal de isômeros purificados de CLA permitiu identificar o CLA trans-10 cis-12 como o responsável pela inibição da secreção de gordura do leite (Baumgard et al., 2000), podendo ainda interagir de forma sinérgica com o CLA cis-9 trans-11 na inibição do crescimento de tumores (Pariza et al., 2001). O efeito do CLA trans-10 cis-12 sobre a síntese de gordura do leite é explicado, pelo menos em parte, por uma inibição da atividade das enzimas lipogênicas acetil-CoA carboxilase e ácido graxo 
sintetase (Piperova et al., 2000), as quais são responsáveis pela síntese de novo de ácidos graxos. A redução na concentração de ácidos graxos de cadeias curtas (C4-C10) e médias (C12-C16) observada no leite dos animais recebendo o CLA trans-10 cis-12 (Loor \& Herbein, 1998; Chouinard et al., 1999, Baumgard et al., 2001) é consistente com o mecanismo de ação descrito acima. Esta alteração no perfil de ácidos graxos do leite é potencialmente benéfica à saúde humana, visto que alguns ácidos graxos de cadeia média (e.g. láurico, mirístico e palmítico) são hipercolesterolêmicos (Williams, 2000) e, portanto, poderiam aumentar o risco da ocorrência de doenças coronárias.

Do ponto de vista produtivo, uma redução da secreção de gordura do leite seria interessante em situações onde há uma reduzida disponibilidade de energia para produção de leite (e.g. vacas de alto potencial genético no início da lactação e vacas em pastejo), uma vez que a gordura é o principal componente energético do leite. Em tais situações, o teor e a produção de proteína do leite dos animais podem ser significativamente aumentados em resposta ao fornecimento de CLA (Medeiros et al., 2000). A melhoria do status energético dos animais devido à menor secreção de energia no leite corroboram ainda a idéia de que a insulina pode exercer um efeito direto ou indireto sobre a secreção de proteína do leite (Mackle et al., 1999). Entretanto, cabe destacar que resultados observados por Medeiros et al. (2000) foram obtidos em condições particulares de alimentação, já que os animais receberam uma dieta que fornecia cerca de $115 \%$ das exigências de proteína metabolizável em relação ao seus níveis de produção. Isto sugere que este maior aporte de proteína da dieta pode ter sido determinante para a obtenção do aumento da secreção de proteína do leite.

Este experimento teve portanto, como objetivo principal, determinar a importância de um maior suprimento de proteína da dieta para obtenção do aumento na secreção de proteína do leite em resposta ao CLA. Outros objetivos incluíram: 1) estudar os efeitos resultantes da redução na secreção de gordura do leite sobre parâmetros produtivos e metabólicos de vacas em início de 
lactação e 2) aumentar o teor de CLA no leite dos animais, acentuando as características nutracêuticas do produto.

\subsection{Material e Métodos}

3.2.1 Local, animais e instalações

O experimento foi realizado no campo experimental do Centro Nacional de Pesquisa em Gado de Leite (CNPGL-Embrapa), que localiza-se na cidade de Coronel Pacheco, estado de Minas Gerais. Foram utilizadas 48 vacas mestiças Holandês x Zebu em início de lactação (30 \pm 5 dias) e produção média de $24 \pm 6 \mathrm{~kg} / \mathrm{dia}$ de leite.

Os animais foram alojados em instalação do tipo "free-stall", com cochos individuais e portões eletrônicos (Calan gates ${ }^{\circledR}$ ) que permitiam o registro individual do consumo de alimentos.

\subsubsection{Delineamento experimental e tratamentos}

Os animais foram blocados em função da produção de leite no início do experimento e do número de lactações. Utilizou-se um arranjo fatorial de tratamentos do tipo $2 \times 2$, correspondentes a dois níveis de proteína na dieta e à suplementação com CLA ou Lac100. Os tratamentos utilizados foram os seguintes:

a) Dieta controle (DC) + Lac100

b) $\mathrm{DC}+\mathrm{CLA}$ encapsulado

c) Dieta com alta proteína (DAP) + Lac100

d) DAP + CLA encapsulado 
As dietas controle e com alta proteína foram formuladas para suprir 100 e 115\% das exigências de proteína metabolizável estimadas pelo Cornell Net Carbohydrate and Protein System (CNCPS v. 4.1), respectivamente. Ambas as dietas foram fornecidas duas vezes ao dia na forma de mistura completa. Os ingredientes utilizados nas dietas experimentais e suas respectivas composições químicas encontram-se na Tabela 1.

Tabela 1. Ingredientes e composição química das dietas

\begin{tabular}{|c|c|c|c|c|}
\hline \multirow[t]{2}{*}{ Ingredientes } & \multicolumn{4}{|c|}{ Dietas } \\
\hline & $\begin{array}{c}\text { DC + } \\
\text { Lac100 }\end{array}$ & $\begin{array}{l}\mathrm{DC}+ \\
\mathrm{CLA}\end{array}$ & $\begin{array}{l}\text { DAP + } \\
\text { Lac100 }\end{array}$ & $\begin{array}{c}\text { DAP + } \\
\text { CLA }\end{array}$ \\
\hline & \multicolumn{4}{|c|}{$\%$ da MS } \\
\hline Silagem de milho & 50 & 50 & 45,4 & 45,4 \\
\hline Milho moído & 24,8 & 24,8 & 23,7 & 23,7 \\
\hline Farelo de soja & 15,8 & 15,8 & 7,1 & 7,1 \\
\hline Glutenose & - & - & 8,4 & 8,4 \\
\hline Casca de soja & 4,4 & 4,4 & 9,9 & 9,9 \\
\hline Fosfato bicálcico & 0,5 & 0,5 & 0,9 & 0,9 \\
\hline Calcário & 0,8 & 0,8 & 0,6 & 0,6 \\
\hline $\mathrm{Sal}(\mathrm{NaCl})$ & 0,5 & 0,5 & 0,5 & 0,5 \\
\hline Uréia & ? & & 0,2 & 0,2 \\
\hline Premix & 0,7 & 0,7 & 0,8 & 0,8 \\
\hline LAC100/CLA & 2,5 & 2,5 & 2,5 & 2,5 \\
\hline \multicolumn{5}{|l|}{ Composição química } \\
\hline FDN, \% MS & 37,5 & 37,5 & 35,9 & 35,9 \\
\hline FDA, $\%$ MS & 16,2 & 16,2 & 15,9 & 15,9 \\
\hline $\mathrm{PB}, \% \mathrm{MS}$ & 16,8 & 16,8 & 19,1 & 19,1 \\
\hline Extrato Etéreo, \% MS & 6,2 & 6,6 & 6,2 & 6,7 \\
\hline PB-FDN, \% PB & 15,5 & 15,5 & 15,6 & 15,6 \\
\hline PB-FDA, \% PB & 7,3 & 7,3 & 7,4 & 7,4 \\
\hline $\mathrm{Ca}, \% \mathrm{MS}$ & 1,05 & 0,75 & 1,11 & 0,81 \\
\hline $\mathrm{P}, \% \mathrm{MS}$ & 0,48 & 0,48 & 0,56 & 0,56 \\
\hline $\mathrm{EL}_{\mathrm{L}}, \mathrm{Mcal} / \mathrm{kg} \mathrm{DM}^{*}$ & 1,68 & 1,70 & 1,70 & 1,72 \\
\hline
\end{tabular}


O perfil de ácidos graxos da silagem de milho e dos concentrados de ambas as dietas (controle e alta proteína) também foram determinados e estas informações são encontradas na Tabela 2.

O produto contendo CLA protegido por encapsulação ("prills") foi fornecido pela Agribrands Inc. e continha cerca de 16\% de CLA, tendo como principais isômeros o cis-9 trans-11, o trans-10 cis-12, o trans-8 cis-10 e o cis11 trans-13. O Lac100 ${ }^{\circledR}$ são sais de cálcio de óleo de soja produzidos pela Yakult, os quais foram utilizados como placebo neste experimento. O perfil de ácidos graxos dos dois suplementos lipídicos encontram-se na Tabela 3. Cada suplemento foi misturado ( $400 \mathrm{~g} / \mathrm{animal} / \mathrm{dia}$ ) a $2 \mathrm{~kg}$ de concentrado de ambas as dietas (controle e alta proteína), conforme o tratamento, e fornecidos pela manhã logo após a pesagem das sobras. 
Tabela 2. Perfil de ácidos graxos da silagem de milho e dos concentrados utilizados (controle e alta proteína)

\begin{tabular}{|c|c|c|c|c|}
\hline \multirow[t]{2}{*}{ Ácido graxo } & \multirow[t]{2}{*}{ Representação } & \multirow[t]{2}{*}{ Silagem de milho } & \multicolumn{2}{|c|}{ Concentrado } \\
\hline & & & Controle & Alta proteína \\
\hline & & & $g / 100 g$ & \\
\hline Caprílico & C8:0 & nd & nd & nd \\
\hline Cáprico & C10:0 & nd & nd & nd \\
\hline Láurico & C12:0 & nd & nd & nd \\
\hline Lauricoléico & C12:1 c9 & nd & nd & nd \\
\hline Mirístico & C14:0 & 0,48 & 0,28 & 0,37 \\
\hline Miristoleico & C14:1 c9 & nd & nd & nd \\
\hline Palmítico & C16:0 & 19,88 & 21,15 & 21,39 \\
\hline Palmitoléico & C16:1 c9 & 0,27 & 0,49 & 0,5 \\
\hline Esteárico & C18:0 & 2,25 & 2,24 & 2,26 \\
\hline Oléico & C18:1 c9 & 29,39 & 31,09 & 32,75 \\
\hline Linoléico & $\mathrm{C} 18: 2$ c9c12 & 41,10 & 42,33 & 40,49 \\
\hline$\alpha$-Linolênico & C18:3 c9c12c15 & 4,13 & 1,82 & 1,68 \\
\hline Aráquico & $\mathrm{C} 20: 0$ & 1,10 & 0,24 & 0,27 \\
\hline 11- Eicosenóico & C20:1 c11 & 1,17 & 0,30 & 0,29 \\
\hline Behênico & C22:0 & nd & 0,06 & nd \\
\hline
\end{tabular}

nd: não detectável $(<0,05 \mathrm{~g} / 100 \mathrm{~g})$ 
Tabela 3. Perfil de ácidos graxos dos suplementos lipídicos

\begin{tabular}{|c|c|c|c|}
\hline \multirow[t]{2}{*}{ Ácido graxo } & \multirow[t]{2}{*}{ Representação } & \multicolumn{2}{|c|}{ Fonte de lipídio } \\
\hline & & CLA & Lac100 \\
\hline & & \multicolumn{2}{|c|}{$\mathrm{g} / 100 \mathrm{~g}$} \\
\hline Láurico & C12:0 & 0,32 & nd \\
\hline Lauricoléico & C12:1 c9 & 0,16 & nd \\
\hline Mirístico & C14:0 & 0,59 & nd \\
\hline Miristoléico & C14:1 c9 & nd & nd \\
\hline Palmítico & C16:0 & 11,12 & 21,39 \\
\hline Palmitoléico & C16:1 с9 & 0,3 & 0,5 \\
\hline Margárico & C17 & 0,11 & nd \\
\hline Esteárico & C18:0 & 4,58 & 2,26 \\
\hline Oléico & C18:1 & 57,59 & 32,55 \\
\hline Vaccênico & C18:1 t11 & 1,28 & nd \\
\hline Linoléico & C18:2 c9c12 & 0,74 & 41,06 \\
\hline$\alpha$-Linolênico & C18:2 c9c12c15 & nd & 1,68 \\
\hline Aráquico & $\mathrm{C} 20: 0$ & 0,74 & 0,27 \\
\hline 8-Eicosenóico & C20:1 c8 & 0,46 & nd \\
\hline 11-Eicosenóico & C20:1 c11 & 0,44 & 0,29 \\
\hline Behênico & C22:0 & 0,71 & nd \\
\hline CLA total & C18:2 & 15,75 & nd \\
\hline \multicolumn{4}{|l|}{ Isômeros: } \\
\hline cis-9 trans-11 & C18:2 c9t11 & 2,4 & nd \\
\hline trans-10 cis- 12 & C18:2 t10c12 & 2,35 & nd \\
\hline cis-11 trans-13 & C18:2 c11t13 & 2,71 & nd \\
\hline trans- 8 cis- 10 & C18:2 t8c10 & 1,18 & nd \\
\hline
\end{tabular}

nd: não detectável $(<0,05 \mathrm{~g} / 100 \mathrm{~g})$ 


\subsubsection{Período experimental}

O experimento foi dividido em três períodos: 1) Pré-tratamento (primeiros 30 dias de lactação), no qual mediu-se a produção de leite dos animais para formação dos blocos e avaliou-se os demais parâmetros para correção dos efeitos de tratamento através do uso de covariável. Além disso, este período foi importante para a adaptação dos animais ao sistema de alimentação em cocho individual (Calan Gates ${ }^{\circledR}$ ), 2) Tratamento (dos 30 aos 72 dias de lactação), no qual os animais receberam os tratamentos propriamente ditos e 3) Residual (dos 72 aos 79 dias de lactação): nesta fase, os animais que estavam recebendo CLA passaram a receber o Lac100, mas as dietas foram mantidas.

Os parâmetros avaliados durante o experimento foram: produção de leite, composição do leite (incluindo o seu perfil de ácidos graxos), contagem de células somáticas (CCS) do leite, consumo de matéria seca, escore de condição corporal e concentração de glicose e ácidos graxos não-esterificados (AGNE) no sangue dos animais.

\subsubsection{Medição da produção de leite e coleta de amostras}

A produção de leite dos animais foi medida diariamente durante todo o experimento. As amostras de leite destinadas à análise de seus componentes $\mathrm{e}$ da sua contagem de células somáticas foram coletadas duas vezes por semana em todos os animais, nas ordenhas da manhã e da tarde, em frascos contendo pastilhas de bromopol. Após a coleta da tarde, as amostras eram enviadas imediatamente para o laboratório de Análise de Leite do CNPGL, onde procediam-se as análises em questão. As amostras destinadas às análises do perfil de ácidos graxos foram coletadas apenas uma vez por semana em frascos sem conservante, sendo em seguida congeladas a $-20^{\circ} \mathrm{C}$. Amostras da silagem e dos concentrados foram coletadas semanalmente e congeladas à $20^{\circ} \mathrm{C}$, sendo posteriormente utilizadas para análise bromatológica e 
determinação do perfil de ácidos graxos (Tabelas 1 e 2). Amostras de sangue foram coletadas semanalmente em tubos de "vacuntainer" contendo EDTA, logo após a ordenha da manhã, através de punção da veia coccígea. O sangue coletado foi imediatamente resfriado e então centrifugado para a obtenção do plasma, o qual foi armazenado a $-20^{\circ} \mathrm{C}$ até a realização das análises.

3.2.5 Avaliação do consumo, peso vivo e escore de condição corporal

A quantidade das dietas fornecidas foi ajustada diariamente para permitir cerca de $5 \%$ de sobras. As sobras foram pesadas diariamente antes da ordenha da manhã, permitindo a obtenção do consumo individual dos animais.

A adaptação dos animais ao Calan Gates foi, conforme já mencionado, realizada no período pré-tratamento, e procedeu-se da seguinte forma: inicialmente, os animais tinham acesso livre a todos os cochos, os quais ficavam com o "portão" de acesso sempre aberto. Após cerca de 3 dias, os portões eram fechados, mas as travas ficavam soltas, de forma que o animal aprendia a empurrar o portão para ter acesso ao alimento. Numa terceira fase, após o sorteio dos tratamentos, os animais recebiam um colar que thes permitiam acesso a um único cocho, cuja trava só se abria para o seu respectivo colar. Uma vez adaptados, os animais iniciavam o período de tratamento propriamente dito. O escore corporal dos animais foi avaliado semanalmente por um único examinador, adotando a escala de 1 (muito magro) a 5 (muito gordo), conforme descrito por Wildman et al. (1982).

\subsubsection{Análises laboratoriais}

Os componentes físico-químicos do leite (gordura, proteína, lactose e sólidos totais) foram determinados por infravermelho e a CCS foi determinada por citometria de fluxo, utilizando-se os aparelhos BENTLEY 2000 e 
SOMACOUNT 300, respectivamente. A concentração de uréia no leite foi determinada por colorimetria utilizando-se kit comercial da Sigma Diagnostics.

A análise do perfil de ácidos graxos do leite iniciou-se com a centrifugação do leite (11.000 rpm por 30') e extração de sua gordura com uma mistura de solventes orgânicos, conforme descrito por Hara \& Radim (1978).

A metilação dos ácidos graxos foi catalisada em solução básica de metóxido de sódio (Christie, 1982). Este procedimento tem sido preferencialmente utilizado, pois catálises ácidas podem resultar na isomerização dos CLAs de configuração cis-trans ou trans-cis para configurações do tipo trans-trans (Kramer et al., 1997).

O perfil de ácidos graxos do leite foi determinado em cromatógrafo gasoso (Marca Thermofinnigan, modelo Trace 2000) equipado com uma coluna capilar de sílica fundida (SP-2560, 100m x 0,25mm x 0,2 $\mu \mathrm{m}$ ) e detector de ionização de chama (FID). O hidrogênio foi utilizado como gás de arraste a um fluxo de $1 \mathrm{ml} / \mathrm{min}$ e as temperaturas do injetor e detector foram de 250 e $300^{\circ} \mathrm{C}$, respectivamente. A razão de injeção das amostras foi de 25:1, o fluxo de ar foi ajustado a $460 \mathrm{ml} / \mathrm{min}$ e o fluxo de nitrogênio (gás auxiliar) a $30 \mathrm{ml} / \mathrm{min}$. A temperatura inicial da forno foi de $70^{\circ} \mathrm{C}$. Quatro minutos após a injeção das amostras, a temperatura foi elevada a $13^{\circ} \mathrm{C} / \mathrm{min}$ até $175^{\circ} \mathrm{C}$ e então mantida por 27 min. Por fim, a temperatura foi elevada a $4^{\circ} \mathrm{C} / \mathrm{min}$ até $215^{\circ} \mathrm{C}$ e mantida por $21 \mathrm{~min}$.

Um padrão de manteiga (CRM 164; Commission of the European Communities, Community Bureau of Reference, Brussels, Belgium) contendo valores certificados para alguns ácidos graxos (especialmente os de cadeia curta) foi utilizado para determinar suas recuperações e calcular os respectivos fatores de correção. A concentração dos ácidos graxos foi expressa em g/100g de ácidos graxos totais. Estas análises foram feitas em apenas 32 animais (8 animais/tratamento), em dois períodos: 1) Pré-tratamento (antes da suplementação lipídica) e 2) Tratamento ( $1^{\underline{a}}$ e $6^{\underline{a}}$ semanas de tratamento). 
Para a determinação do perfil de ácidos graxos dos alimentos, a fração lipídica das amostras foi extraída com hexano por $2 \mathrm{~h}$ a $85^{\circ} \mathrm{C}$, utilizando o sistema Sohlext (refluxo). A metilação dos ácidos graxos foi realizada em solução de metanol em meio ácido ( $10 \%$ de ácido sulfúrico), conforme descrito pela AOCS (1991). Em seguida, o perfil de ácidos graxos foi determinado em cromatógrafo gasoso (Varian 3400), utilizando-se a coluna capilar LM-100 (60m x $0,25 \mathrm{~mm} \times 1 \mu \mathrm{m})$, hidrogênio como gás de arraste $(1 \mathrm{~mL} / \mathrm{min})$ e detector de ionização de chama (FID). As temperaturas do injetor e detector foram de $220 \mathrm{e}$ $240^{\circ} \mathrm{C}$, respectivamente. A razão de injeção das amostras foi de 20:1 e a temperatura do forno foi elevada a $4^{\circ} \mathrm{C} / \mathrm{min}$ de $70^{\circ} \mathrm{C}$ para $230^{\circ} \mathrm{C}$ durante a corrida. Padrões comerciais (Sigma Diagnostics, PA) foram utilizados para identificação dos ácidos graxos das amostras analisadas.

A determinação da concentração de glicose plasmática foi realizada em analisador automático YSI 2700 (Biochemistry Analyser, EUA). Este equipamento possui uma membrana contendo duas enzimas que oxidam a glicose liberando elétrons, os quais geram uma corrente que é medida e comparada com a gerada por uma solução de concentração conhecida (padrão). A concentração de ácidos graxos não-esterificados (AGNE) foi determinada por método enzimático colorimétrico utilizando-se um kit comercial (NEFA C, Wako Pure Chemical Industries, Japan). As leituras de absorbância foram feitas em Leitor de Elisa, utilizando-se microplacas com poços de $200 \mu \mathrm{L}$ onde foram adicionados as amostras, padrões e reagentes. $O$ valor das absorbâncias foram, então, convertidos em concentração ( $\mu \mathrm{mol} / L$ ) através da curva padrão determinada.

\subsubsection{Análise estatística}

Os resultados foram analisados através do programa computacional Statistical Analysis System (SAS Institute Inc., 2000). As análises de variância foram feitas através do procedimento GLM (PROC GLM) com medidas 
repetidas no tempo (comando REPEATED), referentes aos diferentes momentos de coleta durante o período experimental. O modelo estatístico continha os efeitos principais de tratamento, bloco, interação entre tratamentos, tempo e interação tempo $x$ tratamento. Os valores de cada variável obtidos no período pré-tratamento foram utilizados como covariáveis nas análises. As médias corrigidas foram obtidas pelo LSMEANS e as análises de regressão foram feitas através do PROC REG. Adotou-se um nível de significância de 5\% nos testes realizados, mas considerou-se ainda que um determinado efeito tendeu a ocorrer quando $\mathrm{P}<0,1$.

\subsection{Resultados e Discussão}

\subsubsection{Período de Tratamento}

\subsubsection{Desempenho e composição do leite}

A Tabela 4 apresenta as médias e os efeitos dos tratamentos para a produção de leite, composição do leite, consumo de matéria seca e escore corporal dos animais dos 30 aos 72 dias de lactação .

$O$ fornecimento de CLA reduziu significativamente $(P=0,0224)$ o teor de gordura do leite dos animais ao longo de todo o período de tratamento (Figura 1). Esta resposta é consistente com outros estudos nos quais o fornecimento de CLA protegido para vacas leiteiras inibiu a secreção de gordura do leite (Perfield et al., 2002; Giesy et al., 2002; Medeiros et al., 2000). Experimentos com infusão abomasal de isômeros purificados (Baumgard et al, 2000, Baumgard et al., 2001; Peterson et al., 2002) permitiram identificar o CLA trans10 cis-12 como o responsável por este efeito, o qual é conseqüência, em grande parte, de uma redução na síntese de novo de ácidos graxos na glândula mamária (Loor \& Herbein, 1998). 
Embora estatisticamente significativa, a magnitude da redução no teor de gordura do leite observada neste trabalho $(\sim 10 \%)$ foi inferior à observada em estudos onde a mesma dose do CLA trans-10 cis-12 foi administrada através de sais de cálcio de CLA (Perfield et al., 2002; Giesy et al., 2002). No experimento de Giesy et al. (2002), o fornecimento de doses crescentes (0, 4, 9, 17 e 35 g/dia) do CLA trans-10 cis-12 (protegido na forma de sais de cálcio) resultou em uma redução dose-dependente no teor de gordura do leite, alcançando valores de 14 a 39\% para a menor e maior dose, respectivamente. No presente experimento, o fornecimento de $400 \mathrm{~g} / \mathrm{dia}$ de CLA protegido por encapsulação resultou na admimistração de 10g/dia do CLA trans-10 cis-12, quantidade equivalente à segunda maior dose utilizada no experimento de Giesy et al. (2002), a qual reduziu o teor de gordura do leite em cerca de $15 \%$.

Uma quantidade equivalente de CLA trans-10 cis-12 (cerca de $9 \mathrm{~g} / \mathrm{dia}$ ) resultou em uma redução de $23 \%$ no teor de gordura do leite dos animais no experimento de Perfield et al. (2002). Entretanto, é importante destacar que os experimentos citados acima têm duas diferenças básicas em relação a este: o método de proteção ruminal utilizado e o teor de gordura do leite do grupo controle. Nos experimentos de Giesy et al. (2002) e Perfield et al. (2002), os animais controle apresentaram 3,5 e 3,8\% de gordura no leite, respectivamente. Em contraste, o leite dos animais controle do presente experimento apresentou $3 \%$ de gordura (Tabela 4), o que parece explicar em grande parte a menor redução no teor de gordura do leite observada neste trabalho. Uma outra possível explicação para esta resposta seria a forma de proteção ruminal utilizada. No entanto, o teor de gordura no leite dos animais que receberam CLA no presente estudo foi ligeiramente inferior ao observado nos trabalhos citados anteriormente (2,71 vs. 2,9\% para ambos), de forma que o grau de proteção ruminal do CLA (encapsulação vs. sais de cálcio) não parece ter diferido nos dois métodos empregados para este fim. Caso todo o CLA trans-10 cis-12 fornecido neste experimento (10 g/dia) chegasse intacto ao intestino dos animais (100\% de proteção ruminal), poder-se-ia esperar uma redução de cerca 
de $45 \%$ na secreção diária de gordura do leite ( $\mathrm{g} / \mathrm{dia}$ ), de acordo com os dados obtidos em experimento de dose-resposta com infusão abomasal do CLA trans10 cis-12 purificado (Baumgard et al., 2001). Entretanto, a redução na produção de gordura observada neste experimento (cerca de 7\%) sugere, segundo a equação de Baumgard et al. (2001), que apenas 1g/dia do CLA trans-10 cis-12 alcançou o intestino dos animais, indicando um grau de proteção ruminal de apenas 10\%, assumindo-se que não houve perdas por peroxidação durante o armazenamento do produto. Esta conclusão é consistente com os resultados obtidos por Peterson et al. (2002), onde a infusão abomasal de 1,25g/dia do CLA trans-10 cis-12 resultou em uma redução de 7\% na produção de gordura do leite de vacas em lactação. Tanto no experimento de Baumgard et al. (2001) quanto no de Peterson et al. (2002), os teores de gordura do leite no grupo controle foram semelhantes ao obtido neste trabalho $(3,0$ e $3,12 \%$, respectivamente), o que valida tais comparações. Embora estes resultados indiquem uma baixíssima eficiência do método de proteção ruminal utilizado neste experimento, estudo de degradação in situ conduzido por Block \& Jenkins (1994) mostrou que esta resposta pode variar em função da espessura da "cápsula" de gordura envolvendo o que está sendo protegido (e.g. CLA, aminoácido, etc.) e do seu índice iodo (grau de insaturação).

Os demais componentes do leite não foram afetados em resposta ao CLA. Resultados semelhantemente foram obtidos em diversos estudos com CLA protegido ou com infusão abomasal, mesmo quando a secreção de gordura foi grandemente afetada (Chouinard et al., 1999; Peterson et al., 2002; Baumgard et al., 2001; Perfield et al., 2002; Giesy et al., 2002). Em contrapartida, experimentos conduzidos por Medeiros et al. (2000), Giesy et al. (1999) e Bernal-Santos et al. (2001) mostraram aumento da produção de leite e do seu teor de proteína em resposta ao fornecimento de sais de cálcio de CLA. Entretanto, cabe destacar que nestes trabalhos, ao contrário dos demais, as vacas estavam em início de lactação (Giesy et al., 1999 e Bernal \& Santos et al., 2001) ou em pastejo (Medeiros et al., 2000), e portanto numa situação onde 
a ingestão de energia é geralmente inferior aos requerimentos produtivos. Nestas situações, a redução da secreção de gordura no leite em resposta ao CLA pode ter permitido aos animais direcionar esta "sobra" de energia para a síntese de outros componentes do leite, como lactose ou proteína (Baumgard, 2003).

No presente experimento, embora as vacas estivessem também em início de lactação (cerca de 30 dias pós-parto), os animais não eram de alto potencial produtivo, e o consumo de energia pela dieta excedeu a demanda para máxima produção de leite, o que pôde ser comprovado pelo ganho de escore corporal dos animais ao longo do período de tratamento (dados não apresentados). Neste caso, poder-se-ia esperar uma maior recuperação do escore corporal ou ainda uma redução no consumo de alimentos nos animais que receberam CLA. Entretanto, conforme já mencionado, a baixa eficiência de proteção ruminal do CLA aliada aos baixos teores de gordura no leite dos animais que receberam Lac100 (grupo controle) não permitiram uma redução significativa $(P>0,1)$ da secreção de gordura do leite, de forma que tais hipóteses não puderam ser testadas.

O fornecimento de uma dieta com alta proteína (DAP) aumentou a concentração de uréia no leite dos animais (Tabelas 4 e 5). Esta resposta é consistente com os resultados de simulação obtidos no CNCPS a partir da composição da dieta fornecida, consumo de matéria seca e resposta produtiva dos animais. A simulação mostrou que, de fato, a ingestão da dieta com alta proteína forneceu um excesso de proteína metabolizável em relação à exigência dos animais. Portanto, este excesso de aminoácidos foi possivelmente desaminado e a amônia produzida então convertida à uréia no fígado dos animais, aumentando seu teor no leite. A tendência $(P=0,08)$ para maior produção de gordura e de sólidos totais do leite nos animais que receberam a dieta com alta proteína foi conseqüência do ligeiro aumento numérico $(P>0,1)$ da produção de leite e do seu teor de gordura em resposta a esse tratamento (Tabela 4). 
Tabela 4. Desempenho e composição do leite dos animais durante o período de tratamento

\begin{tabular}{|c|c|c|c|c|c|c|c|}
\hline \multirow[t]{2}{*}{ Parâmetros } & \multicolumn{4}{|c|}{ Tratamentos } & \multirow[t]{2}{*}{ CV (\%) } & \multicolumn{2}{|c|}{$P^{1}$} \\
\hline & $\begin{array}{c}\text { DC + } \\
\text { Lac100 }\end{array}$ & $\begin{array}{l}\mathrm{DC}+ \\
\mathrm{CLA}\end{array}$ & $\begin{array}{c}\text { DAP + } \\
\text { Lac100 }\end{array}$ & $\begin{array}{c}\text { DAP + } \\
\text { CLA }\end{array}$ & & $\mathrm{FL}$ & NPD \\
\hline Produção de leite, kg/d & 22,9 & 23,7 & 25,3 & 25,4 & 22,9 & NS & NS \\
\hline Composição do leite, \% & & & & & & & \\
\hline Gordura & 2,93 & 2,63 & 3,07 & 2,79 & 19,1 & * & NS \\
\hline Proteína & 2,89 & 2,88 & 2,87 & 2,82 & 8,3 & NS & NS \\
\hline Lactose & 4,74 & 4,68 & 4,76 & 4,79 & 4,7 & NS & NS \\
\hline Sólidos totais & 11,4 & 11,1 & 11,7 & 11,3 & 6,5 & $\dagger$ & NS \\
\hline Prod. dos componentes, $\mathrm{k}$ & & & & & & & \\
\hline Gordura & 0,69 & 0,64 & 0,78 & 0,74 & 29,6 & NS & $\dagger$ \\
\hline Proteína & 0,67 & 0,68 & 0,72 & 0,74 & 20,4 & NS & NS \\
\hline Lactose & 1,10 & 1,11 & 1,20 & 1,25 & 22,1 & NS & NS \\
\hline Sólidos totais & 2,69 & 2,62 & 2,96 & 2,95 & 22,1 & NS & $\dagger$ \\
\hline CCS, $\left[\log _{2}\left(\operatorname{CCS} / 10^{5}\right)+3\right]$ & 1,75 & 2,42 & 3,20 & 2,93 & 116,0 & NS & NS \\
\hline Uréia no leite, mg/dl & 34,7 & 35,7 & 39,1 & 39,9 & 19,5 & NS & $\star \star *$ \\
\hline Consumo de MS, kg/d & 15,7 & 16,3 & 16,9 & 16,4 & 14,7 & NS & NS \\
\hline Consumo de MS, \% PV & 3,5 & 3,4 & 3,6 & 3,4 & 11,2 & NS & NS \\
\hline Escore corporal & 3,13 & 3,19 & 3,20 & 3,14 & 15,4 & NS & NS \\
\hline
\end{tabular}

${ }^{1}$ Efeitos principais (as interações não foram significativas, $P>0,1$ )

FL: Efeito da fonte de lipídio, NPD: Efeito do nível de proteína da dieta

NS: Não significativo $(P>0,1), \dagger P<0,1,{ }^{*} P<0,05$, ** $P<0,01$

DC: Dieta controle, DAP: Dieta com alta proteína

CV: Coeficiente de variação

Escore corporal: 1 (muito magra) a 5 (muito gorda)

CCS: Contagem de células somáticas (escore linear) 


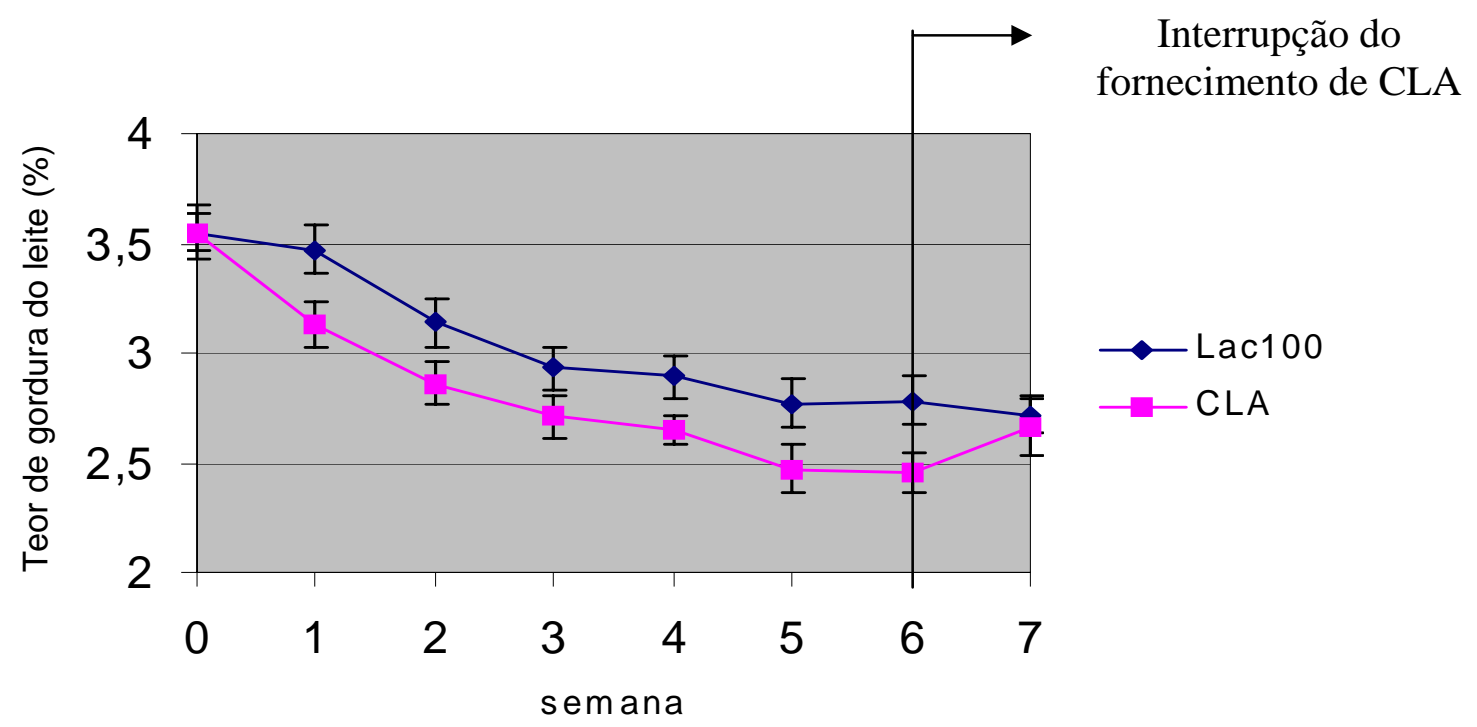

Figura 1 - Teor de gordura do leite dos animais que receberam CLA ou Lac100

3.3.1.2 Perfil de ácidos graxos do leite

Os efeitos de tratamento apresentados nas Tabelas 5 e 6 são relativos à análise de variância para todo o período de tratamento (média das semanas $1 \mathrm{e}$ 6). Em caso de interação singificativa $(P<0,05)$ entre tempo e tratamento, os efeitos foram apresentados para cada tempo.

Analisando-se a Tabelas 6 e a Figura 2, nota-se que a suplementação dos animais com CLA ou Lac100, independentemente do nível de proteína da dieta, reduziu significativamente (efeito de tempo, $P<0,05$ ) a concentração dos ácidos graxos de cadeias curta (C4-C10) e média (C12-C16), enquanto aumentou a dos ácidos graxos de cadeia longa no leite dos animais ao longo do período de tratamento. Estes resultados sugerem uma inibição da síntese de novo de ácidos graxos na glândula mamária em resposta à suplementação com CLA ou Lac100, possivelmente por ação direta do CLA trans-10 cis-12 (Baumgard et al., 2000), uma vez que houve um aumento significativo da sua 
concentração no leite dos animais após o início da suplementação lipídica (efeito de tempo, $\mathrm{P}<0,01$ ), independentemente da fonte. Corroborando estes resultados, estudos com vacas em lactação (Piperova et al., 2000) e com ratos (Hayashi et al., 2002) demonstraram que o maior teor do CLA trans-10 cis-12 no leite está associado à uma redução na atividade das enzimas lipogênicas acetil-CoA carboxilase (ACC) e sintase de ácido graxo (FAS). Uma vez que a formação do CLA trans-10 cis-12 se dá exclusivamente no rúmen dos animais (Bauman et al., 1999) sob condições de baixo pH e presença de lipídios insaturados (Griinari et al., 1998), os resultados obtidos neste experimento indicam que os sais de cálcio de óleo de soja (Lac100) foram dissociados no rúmen, permitindo que as bactérias sintetizassem este isômero a partir do ácido linoléico presente em altas concentrações no óleo de soja. Esta hipótese é reforçada pela menor concentração de ácido linoléico $(P=0,01)$ e maiores concentrações de ácido vaccênico $(P=0,02)$ e do CLA cis-9 trans-11 $(P=0,0001)$ encontrado no leite dos animais que receberam Lac100 (Figura 3), mesmo com este produto apresentando uma concentração de ácido linoléico muito superior à presente no CLA encapsulado (Tabela 3). Estes resultados são consistentes com os obtidos por Chouinard et al. (2001), onde a inclusão de sais de cálcio de óleo de soja a uma dieta controle aumentou em seis vezes a concentração de CLA cis-9 trans-11 no leite de vacas em lactação. Experimento conduzido por Sukhija \& Palmquist (1990) demonstrou claramente que o grau de proteção ruminal dos sais de cálcio de ácidos graxos (sabões) depende da fonte de lipídios utilizada, ou melhor, do seu grau de insaturação. Estes autores encontraram valores de pk ( $\mathrm{pH}$ onde há $50 \%$ de dissociação) de 5,6 para sais de cálcio de óleo de soja e de 4,5 para sais de cálcio de lipídios basicamente saturados, como os de palma (e.g. MEGALAC) e sebo bovino. Estes resultados indicam que a dissociação de sais de cálcio de óleo de soja podem ser de fato consideráveis em condições de baixo $\mathrm{pH}$ ruminal, o que provavelmente aconteceu com os animais deste experimento, uma vez que recebiam dieta com 
alto teor de concentrados e silagem de milho como fonte exclusiva de volumoso.

Se a dissociação dos sais de cálcio aumenta com a queda no $\mathrm{pH}$ ruminal, poder-se-ia esperar uma menor concentração de ácido linoléico e, possivelmente, devido à biohidrogenação ruminal, uma maior concentração do CLA cis-9 trans-11 e do ácido vaccênico no leite dos animais recebendo a dieta com alta proteína. Isto porque esta dieta apresentou menor teor de fibra (Tabela 1) e ainda uma substituição de parte da fibra longa (silagem) por fibra de menor efeito físico (casca de soja). Entretanto, uma resposta oposta foi observada (Figura 4), embora o efeito para o CLA cis-9 trans-11 não tenha sido estatisticamente significativo $(P>0,1)$. Esta contradição talvez possa ser explicada pelo efeito do $\mathrm{pH}$ sobre a lipólise dos fosfolipídios e galactolipídios presentes na dieta basal, uma vez que o baixo $\mathrm{pH}$ ruminal pode reduzir a atividade lipolítica das bactérias (Jenkins, 1993).

Outro efeito aparentemente contraditório encontrado neste trabalho foi a maior concentração $(P=0,01)$ de ácido $\alpha$-linolênico no leite dos animais que receberem CLA, embora a concentração deste ácido graxo fosse ligeiramente superior no Lac100 (Tabela 3). Esta resposta, no entanto, talvez seja explicada pelo maior teor de cálcio da dieta com Lac100 (Tabela 1), pois um excesso de cálcio na dieta pode resultar na formação de sabões insolúveis no intestino, os quais serão excretados nas fezes (Jenkins \& Palmquist, 1984). Isto explicaria também o menor teor do ácido linoléico no leite dos animais que receberam Lac100 (Tabela 5), embora esta resposta só tenha sido observada na última semana de tratamento (interação tempo vs. tratamento).

Outra importante variável avaliada neste experimento foi a atividade da enzima $\Delta-9$ dessaturase, medida indiretamente pela relação entre substratos e produtos desta enzima (Tabela 6). Esta enzima tem importância fundamental na manutenção da fluidez da gordura no leite, pois a dessaturação de ácidos graxos saturados de cadeia longa, especialmente o ácido esteárico, reduz significativamente o seu ponto de fusão (Chilliard et al., 2000). Além disso, a 
maior parte do CLA cis-9 trans-11 presente no leite é sintetizada endogenamente por ação da enzima $\Delta-9$ dessaturase, a partir do ácido vaccênico produzido no rúmen (Corl et al., 1998; Griinari et al., 2000).

Estudo conduzido por Baumgard et al. (2001) mostrou, através da análise das relações substrato/produto, que a infusão abomasal de 7 ou 14g/dia de CLA trans-10 cis-12 reduziu significativamente a atividade da enzima $\Delta-9$ dessaturase na glândula mamária de vacas em lactação. Estes resultados foram confirmados pela medição direta da abundância do RNA mensageiro dos genes que codificam esta enzima, após infusão abomasal de 14 g/dia do CLA trans-10 cis-12 (Baumgard et al., 2002).

No presente experimento, embora a concentração de CLA trans-10 cis12 no leite não tenha sido estatisticamente diferente entre os animais que receberam Lac100 e CLA (Tabela 5), foi possível detectar um aumento $(P<0,05)$ da relação entre C14:0 e C14:1 em resposta ao CLA (Tabela 6), o que sugere uma redução na atividade da enzima $\Delta-9$ dessaturase. A baixa concentração de CLA trans-10 cis-12 no leite dos animais que receberam CLA encapsulado (cerca de $0,07 \mathrm{~g} / 100 \mathrm{~g}$ ) em relação aos demais experimentos onde foi observada uma redução na atividade desta enzima $(>0,32 \mathrm{~g} / 100 \mathrm{~g})$ em resposta à infusão abomasal do CLA trans-10 cis-12 parece indicar que este isômero, de fato, não foi o responsável por esta resposta neste experimento. Bauman et al. (2001) especularam que outro isômero do CLA, o trans-8 cis-10, poderia também inibir a síntese de gordura do leite, e a inibição da atividade da $\Delta-9$ dessaturase seria uma maneira de explicar este efeito. Esta especulação é baseada no estudo de Chouinard et al. (1999), onde vacas que receberam infusão abomasal de uma mistura de isômeros de CLA contendo 22\% do CLA trans-8 cis-10 mas sem o CLA trans-10 cis-12 apresentaram $28 \%$ de redução do teor de gordura do leite. Além disso, a depressão de gordura do leite (DGL) observada em estudos com CLA protegido (mistura de diferentes isômeros) é muito maior do que poderia ser predito baseado na concentração do CLA trans10 cis-12 no leite em estudos onde administrou-se este isômero puro. 
Entretanto, a infusão abomasal de CLA trans-8 cis-10 (isômero puro) em recente estudo (Perfield et al., 2003) não reduziu a secreção de gordura do leite de vacas em lactação. Portanto, é possível que algum isômero do CLA não identificado no estudo de Chouinard et al. (1999) tenha causado a DGL. Além disso, a biohidrogenação ruminal dos isômeros de CLA presentes em fontes comerciais poderia resultar na formação de compostos capazes de causar DGL (Mikko Griinari, comunicação pessoal). Esta última hipótese poderia explicar também o menor teor de gordura no leite dos animais que receberam CLA encapsulado no presente estudo (Tabela 4, Figura 1), apesar de ambos os grupos apresentarem mesma concentração do CLA trans-10 cis-12 (Tabela 6).

Experimentos conduzidos nos últimos anos têm demonstrado uma associação negativa entre as concentrações de ácidos graxos C18:1 trans e o teor de gordura no leite de vacas com DGL (Bauman \& Griinari, 2001). Griinari et al. (1998) mostraram que duas condições são necessárias para a ocorrência de DGL: um baixo pH ruminal (situação tipicamente encontrada em vacas ingerindo dieta com baixo teor de fibra) e presença de uma fonte de lipídios poliinsaturados na dieta (e.g. óleo de milho). Em tais condições, há uma alteração na via de biohidrogenação ruminal no sentido da formação do CLA trans-10 cis-12, o qual pode ser reduzido à C18:1 trans-10 pelas bactérias ruminais. Ambos os ácidos graxos são absorvidos no intestino e suas concentrações no leite aumentam significativamente (Piperova et al., 2000). A associação entre a concentração de CLA trans-10 cis-12 e o teor de gordura do leite das vacas tratadas com CLA ou Lac100 $\left(r^{2}=0,47\right)$, observada na Figura 5, reforça o conceito de que esta molécula está intimamente relacionada à depressão da gordura do leite (DGL). A equação de regressão encontrada no presente experimento [\% gordura do leite $=3,69-30,8$ (\% CLA t10c12) $+172,2$ $\left.(\% \mathrm{CLA} \mathrm{t10c12})^{2}\right]$ foi semelhante às obtidas recentemente em pesquisas do nosso grupo com vacas a pasto (Medeiros, 2002) e parece justificar, pelo menos em parte, a redução observada ao longo do tempo no teor de gordura do 
leite dos animais que receberam tanto o CLA encapsulado como Lac100 (Figura 1).

Um aspecto importante é que a curva de regressão feita para cada tratamento (CLA e Lac100), separadamente, apresentaram pontos de mínimo (valor do eixo " $X$ " associado ao menor valor em " $Y$ ") iguais $(X=0,08)$, mas o valor associado a este ponto (teor de gordura do leite) foi numericamente inferior $(2,2 \times 2,5 \%)$ nos animais que receberam CLA. Este resultado é consistente com a hipótese de que outros ácidos graxos, além do CLA trans-10 cis-12, inibiram a secreção de gordura do leite nos animais que receberam CLA encapsulado.

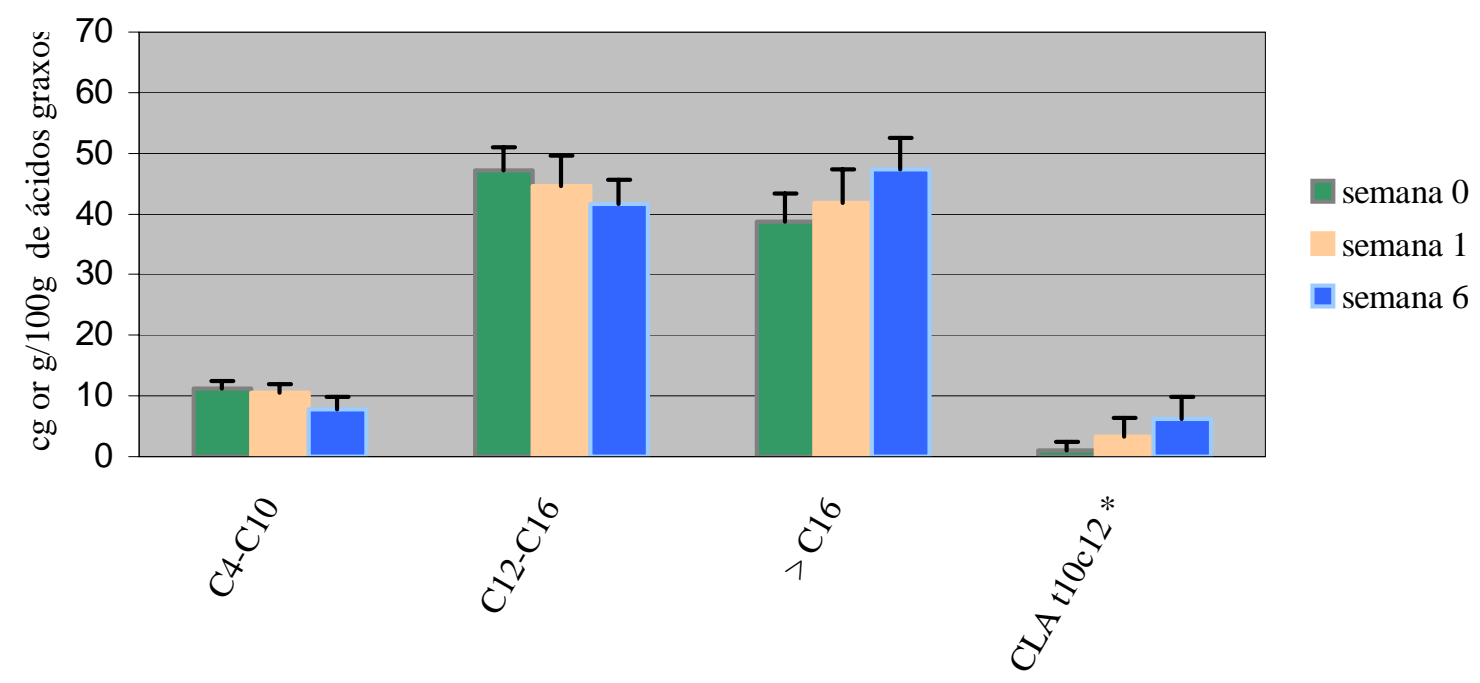

ácidos graxos

Figura 2 - Variação temporal do perfil de ácidos graxos do leite dos animais, independentemente do tratamento (*expresso como $\mathrm{cg} / 100 \mathrm{~g}$ de gordura) 
Tabela 5. Perfil de ácidos graxos do leite dos animais antes (semana 0) e durante o período de tratamento ( $1^{\underline{a}}$ e $6^{\underline{a}}$ semanas)

\begin{tabular}{|c|c|c|c|c|c|c|c|c|}
\hline \multirow[t]{2}{*}{ Ácido graxo } & \multirow[b]{2}{*}{ semana } & \multicolumn{4}{|c|}{ Tratamentos } & \multicolumn{2}{|c|}{$P^{1}$} & \multirow[t]{2}{*}{ CV (\%) } \\
\hline & & $\begin{array}{c}\text { DC + } \\
\text { Lac100 }\end{array}$ & $\begin{array}{l}\mathrm{DC}+ \\
\mathrm{CLA}\end{array}$ & $\begin{array}{l}\text { DAP + } \\
\text { Lac100 }\end{array}$ & $\begin{array}{c}\text { DAP + } \\
\text { CLA }\end{array}$ & $\mathrm{FL}$ & NPD & \\
\hline & 0 & 4,04 & 4,04 & 4,04 & 4,04 & & & 9,3 \\
\hline \multirow[t]{3}{*}{ C4:0 } & 1 & 3,85 & 4,25 & 4,37 & 4,35 & & & 9,8 \\
\hline & 6 & 3,13 & 3,14 & 3,31 & 3,82 & NS & NS & 20,7 \\
\hline & 0 & 2,56 & 2,56 & 2,56 & 2,56 & & & 9,9 \\
\hline \multirow{3}{*}{ C6:0 } & 1 & 2,29 & 2,47 & 2,49 & 2,27 & & & 13,9 \\
\hline & 6 & 1,52 & 1,60 & 1,65 & 1,92 & NS & NS & 29,6 \\
\hline & 0 & 1,47 & 1,47 & 1,47 & 1,47 & & & 13,8 \\
\hline \multirow[t]{3}{*}{ C8:0 } & 1 & 1,24 & 1,37 & 1,37 & 1,27 & & & 19,8 \\
\hline & 6 & 0,77 & 0,81 & 0,87 & 1,06 & NS & NS & 39,4 \\
\hline & 0 & 3,18 & 3,18 & 3,18 & 3,18 & & & 18,0 \\
\hline \multirow[t]{3}{*}{ C10:0 } & 1 & 2,59 & 2,90 & 2,80 & 2,63 & & & 23,5 \\
\hline & 6 & 1,68 & 1,75 & 1,89 & 2,30 & NS & NS & 40,2 \\
\hline & 0 & 3,52 & 3,52 & 3,52 & 3,52 & & & 17,0 \\
\hline \multirow[t]{3}{*}{ C12:0 } & 1 & 2,86 & 3,23 & 3,13 & 2,96 & & & 22,3 \\
\hline & 6 & 2,06 & 2,29 & 2,21 & 2,72 & NS & NS & 32,6 \\
\hline & 0 & 11,1 & 11,1 & 11,1 & 11,1 & & & 10,2 \\
\hline \multirow{3}{*}{ C14:0 } & 1 & 9,99 & 11,1 & 10,2 & 9,8 & & & 13,6 \\
\hline & 6 & 8,73 & 8,42 & 8,99 & 9,77 & NS & NS & 17,0 \\
\hline & 0 & 0,81 & 0,81 & 0,81 & 0,81 & & & 22,9 \\
\hline \multirow{3}{*}{ C14:1 c9 } & 1 & 0,79 & 0,78 & 0,89 & 0,69 & & & 28,2 \\
\hline & 6 & 0,88 & 0,84 & 0,94 & 0,88 & NS & NS & 32,4 \\
\hline & 0 & 30,2 & 30,2 & 30,2 & 30,2 & & & 9,9 \\
\hline \multirow[t]{3}{*}{ C16:0 } & 1 & 29,5 & 29,9 & 30,1 & 27,8 & & & 14,9 \\
\hline & 6 & 28,5 & 28,3 & 29,7 & 26,6 & NS & NS & 15,9 \\
\hline & 0 & 1,24 & 1,24 & 1,24 & 1,24 & & & 22,1 \\
\hline \multirow[t]{3}{*}{ C16:1 c9 } & 1 & 1,08 & 1,09 & 1,18 & 1,10 & NS & NS & 15,5 \\
\hline & 6 & 1,29 & 1,23 & 1,40 & 1,02 & $\dagger$ & NS & 24,8 \\
\hline & 0 & 14,6 & 14,6 & 14,6 & 14,6 & & & 17,8 \\
\hline \multirow[t]{3}{*}{ C18:0 } & 1 & 13,7 & 13,1 & 13,1 & 15,6 & & & 17,9 \\
\hline & 6 & 14,3 & 14,4 & 14,2 & 14,5 & NS & NS & 16,6 \\
\hline & 0 & 17,9 & 17,9 & 17,9 & 17,9 & & & 13,5 \\
\hline \multirow[t]{3}{*}{ C18:1 c9 } & 1 & 18,1 & 17,5 & 18,2 & 19,9 & & & 15,4 \\
\hline & 6 & 22,0 & 21,7 & 21,6 & 22,6 & NS & NS & 15,5 \\
\hline & 0 & 1,63 & 1,63 & 1,63 & 1,63 & & & 16,5 \\
\hline \multirow[t]{3}{*}{ C18:2 c9c12 } & 1 & 1,70 & 1,78 & 1,76 & 1,94 & NS & NS & 18,6 \\
\hline & 6 & 1,86 & 2,16 & 2,14 & 2,66 & $\star \star$ & $\star \star$ & 17,4 \\
\hline & 0 & 0,16 & 0,16 & 0,16 & 0,16 & & & 16,6 \\
\hline \multirow[t]{3}{*}{ C18:3 c9c12c15 } & 1 & 0,17 & 0,18 & 0,15 & 0,20 & & & 21,0 \\
\hline & 6 & 0,15 & 0,20 & 0,16 & 0,19 & $\star \star$ & NS & 25,0 \\
\hline & 0 & 1,86 & 1,86 & 1,86 & 1,86 & & & 21,2 \\
\hline \multirow{2}{*}{ C18:1 t11 } & 1 & 5,28 & 4,03 & 4,37 & 2,93 & & & 47,5 \\
\hline & 6 & 5,98 & 4,85 & 4,89 & 3,32 & * & * & 42,5 \\
\hline \multicolumn{9}{|c|}{$\begin{array}{l}\text { Efeitos principais (as interações não foram significativas, } \\
\text { FL: Efeito da fonte de lipídio, NPD: Efeito do nível de prc } \\
\text { NS: Não significativo }(P>0,1), \dagger P<0,1,{ }^{*} P<0,05,{ }^{*} P<0 \\
\text { DC: Dieta controle, DAP: Dieta com alta proteína } \\
\text { CV: Coeficiente de variação }\end{array}$} \\
\hline
\end{tabular}




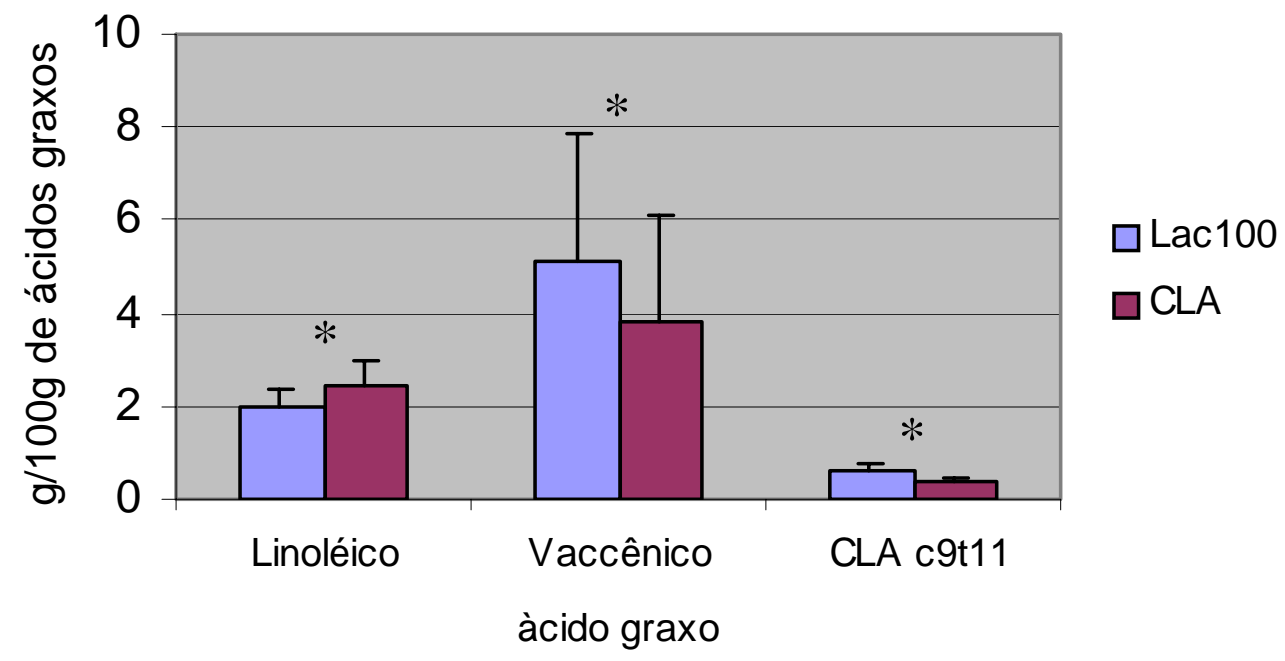

Figura 3 - Concentrações de ácido linoléico, ácido vaccênico and CLA cis-9 trans-11 no leite dos animais tratados com CLA ou Lac100 $\left({ }^{\star} \mathrm{P}<0,05\right)$

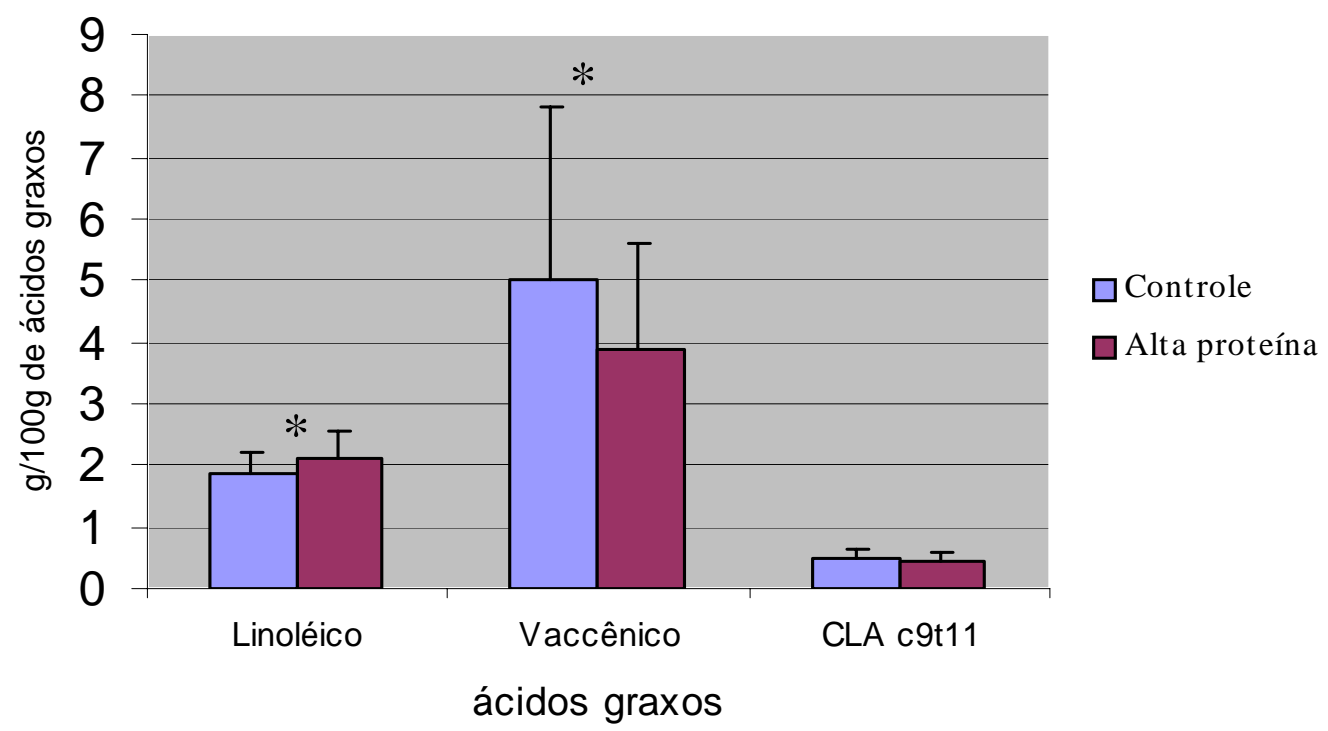

Figura 4 - Efeitos do nível de proteína da dieta sobre as concentrações de ácido linoléico, ácido vaccênico e CLA cis-9 trans-11 no leite dos animais durante o período de tratamento (* $P<0,05$ ) 


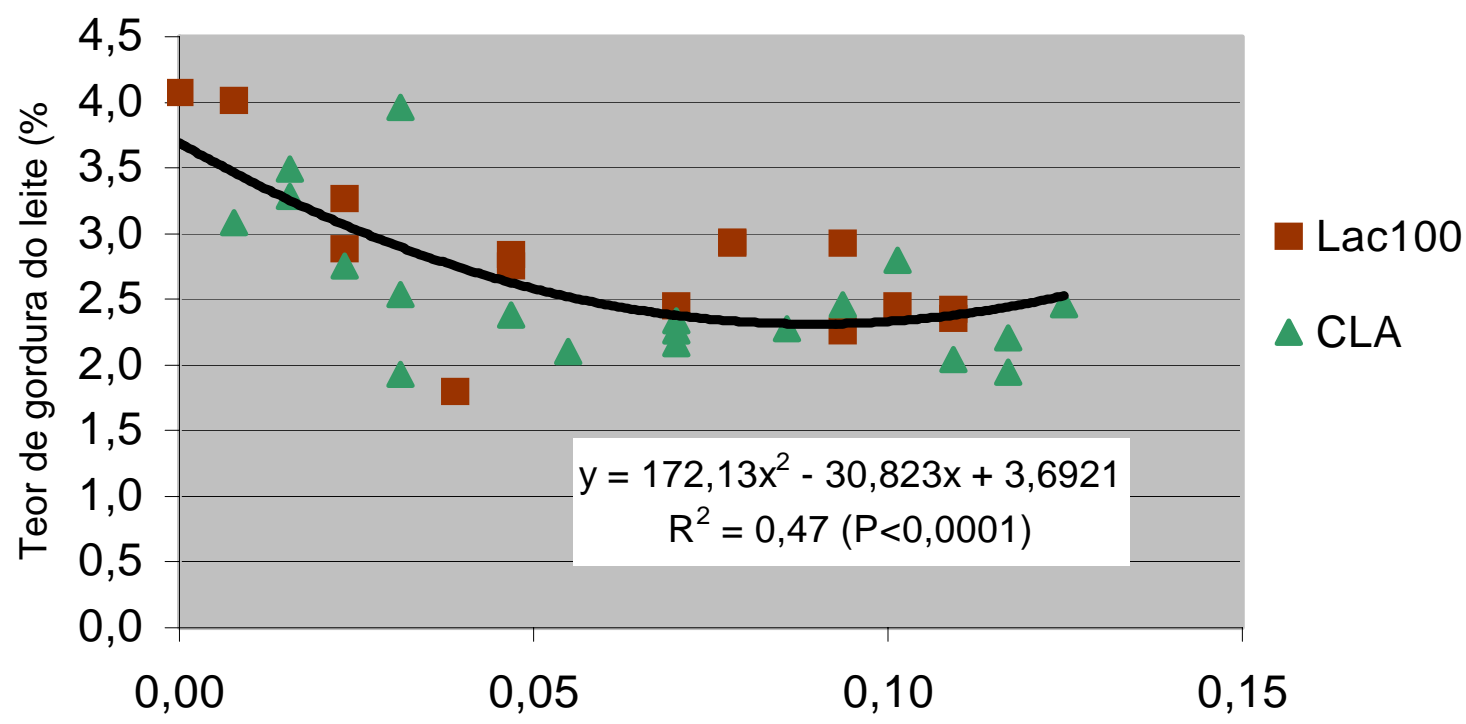

CLA trans-10 cis-12 (g/100g de ácidos graxos)

Figura 5 - Regressão entre a concentração de CLA trans-10 cis-12 CLA e o teor de gordura do leite dos animais tratados com CLA ou Lac100 (dados obtidos da $6^{\text {a }}$ semana de tratamento) 
Tabela 6. Concentração (g/100g) dos ácidos graxos de cadeias curta (C4-C10), média (C12-C16) e longa (C18 total), dos isômeros do CLA e relações entre substratos e produtos da enzima $\Delta-9$ dessaturase no leite dos animais antes (semana 0 ) e durante o período de tratamento ( $1^{\underline{a}}$ and $6^{\underline{a}}$ semanas)

\begin{tabular}{|c|c|c|c|c|c|c|c|c|}
\hline \multirow[t]{2}{*}{ Ácido graxo } & \multirow[b]{2}{*}{ semana } & \multicolumn{4}{|c|}{ Tratamentos } & \multicolumn{2}{|c|}{$P^{1}$} & \multirow[t]{2}{*}{ CV (\%) } \\
\hline & & $\begin{array}{c}\text { DC + } \\
\text { Lac100 }\end{array}$ & $\begin{array}{l}\mathrm{DC}+ \\
\mathrm{CLA}\end{array}$ & $\begin{array}{c}\text { DAP + } \\
\text { Lac100 }\end{array}$ & $\begin{array}{c}\text { DAP + } \\
\text { CLA }\end{array}$ & $\mathrm{FL}$ & NPD & \\
\hline & 0 & 11,3 & 11,3 & 11,3 & 11,3 & & & 10,1 \\
\hline \multirow[t]{3}{*}{ C4-C10 } & 1 & 9,9 & 11,1 & 11,0 & 10,4 & & & 13,0 \\
\hline & 6 & 7,0 & 7,3 & 7,8 & 9,2 & NS & NS & 26,6 \\
\hline & 0 & 47,2 & 47,2 & 47,2 & 47,2 & & & 7,9 \\
\hline \multirow[t]{3}{*}{ C12-C16 } & 1 & 44,6 & 46,4 & 44,6 & 42,7 & & & 11,1 \\
\hline & 6 & 41,5 & 42,5 & 41,0 & 41,6 & NS & NS & 9,5 \\
\hline & 0 & 38,8 & 38,8 & 38,8 & 38,8 & & & 11,6 \\
\hline \multirow[t]{3}{*}{ C18 total } & 1 & 42,3 & 39,5 & 42,0 & 43,7 & & & 13,5 \\
\hline & 6 & 48,2 & 46,5 & 49,0 & 45,8 & NS & NS & 10,9 \\
\hline & 0 & 14,2 & 14,2 & 14,2 & 14,2 & & & 21,5 \\
\hline \multirow[t]{3}{*}{ C14:0/14:1c9 } & 1 & 13,3 & 15,2 & 11,7 & 14,8 & * & NS & 23,9 \\
\hline & 6 & 10,5 & 12,6 & 9,9 & 11,6 & $\dagger$ & NS & 27,2 \\
\hline & 0 & 25,8 & 25,8 & 25,8 & 25,8 & & & 19,3 \\
\hline \multirow[t]{3}{*}{ C16:0/16:1c9 } & 1 & 28,9 & 28,2 & 26,8 & 24,8 & & & 14,0 \\
\hline & 6 & 23,6 & 24,7 & 22,3 & 25,7 & NS & NS & 19,9 \\
\hline & 0 & 0,79 & 0,79 & 0,79 & 0,79 & & & 18,8 \\
\hline \multirow{3}{*}{ C18:0/18:1c9 } & 1 & 0,73 & 0,73 & 0,64 & 0,76 & & & 16,8 \\
\hline & 6 & 0,62 & 0,65 & 0,56 & 0,63 & NS & NS & 19,5 \\
\hline & 0 & 0,33 & 0,33 & 0,33 & 0,33 & & & 24,9 \\
\hline \multirow[t]{3}{*}{ c9t11 CLA } & 1 & 0,63 & 0,35 & 0,64 & 0,38 & ** & NS & 39,3 \\
\hline & 6 & 0,54 & 0,40 & 0,50 & 0,31 & $\star \star$ & NS & 28,7 \\
\hline & 0 & 0,01 & 0,01 & 0,01 & 0,01 & & & 146,1 \\
\hline \multirow[t]{2}{*}{ t10c12 CLA } & 1 & 0,03 & 0,04 & 0,02 & 0,04 & & & 93,9 \\
\hline & 6 & 0,07 & 0,07 & 0,06 & 0,05 & NS & NS & 56,8 \\
\hline
\end{tabular}




\subsubsection{Parâmetros metabólicos}

A concentração plasmática de AGNE não foi afetada pelo fornecimento de CLA (Tabela 7). Esta resposta já era esperada, uma vez que a secreção de gordura do leite não foi significativamente reduzida em resposta a este tratamento (Tabela 4). Como o consumo de MS também não foi alterado, o balanço energético das vacas permaneceu o mesmo em ambos os tratamentos (CLA e Lac100).

Com relação à concentração de glicose, algum aumento poderia ter sido observado na dieta com alta proteína, uma vez que os maiores níveis de uréia no leite dos animais que receberam esta dieta (Tabela 4) indicam uma maior utilização dos aminoácidos para oxidação ou gliconeogênese. Entretanto, este efeito foi aparentemente compensado pelo aumento numérico ( $P>0,1$, Tabela 4) de aproximadamente $2 \mathrm{~kg} /$ dia na produção de leite dos animais em resposta à dieta com alta proteína. Em outras palavras, o aumento da gliconeogênese pode ter sido compensado pela maior secreção de lactose no leite, de forma que a glicemia manteve-se inalterada. Além disso, a concentração de glicose no sangue é controlada por mecanismos homeostáticos, de forma que efeitos sobre este parâmetro não são normalmente detectados (Bauman, 2000).

Tabela 7. Concentrações de glicose e ácidos graxos não-esterificados (AGNE) no sangue dos animais durante o período de tratamento

\begin{tabular}{cccccccc}
\hline Parâmetros & \multicolumn{4}{c}{ Tratamentos } & \multicolumn{2}{c}{ CV (\%) } & \multicolumn{2}{c}{$P^{1}$} \\
& $\mathrm{DC}+$ & $\mathrm{DC}+$ & DAP + & DAP + & & FL & NPD \\
& Lac100 & CLA & Lac100 & CLA & & & \\
\hline Glicose $(\mathrm{mg} / \mathrm{dl})$ & 56,6 & 58,5 & 57,9 & 56,8 & 12,4 & NS & NS \\
AGNE $(\mu \mathrm{mol} / \mathrm{l})$ & 146,0 & 158,2 & 158,8 & 163,0 & 49,8 & NS & NS \\
\hline
\end{tabular}

${ }^{1}$ Efeitos principais (as interações não foram significativas, $\mathrm{P}>0,1$ )

FL: Efeito da fonte de lipídio, NPD: Efeito do nível de proteína da dieta

NS: Não significativo $(P>0,1), \dagger P<0,1,{ }^{*} P<0,05,{ }^{* \star} P<0,01$

DC: Dieta controle, DAP: Dieta com alta proteína

CV: Coeficiente de variação 


\subsubsection{Período residual}

O teor de gordura do leite dos animais aumentou após a interrupção do fornecimento do CLA, alcançando valores próximos aos do grupo de animais que já vinham recebendo Lac100 (Figura 2). Portanto, ambos os tratamentos apresentaram o mesmo teor de gordura do leite ao final do período residual (Tabela 8).

Estes resultados sugerem que o efeito inibitório sobre a síntese de gordura do leite foi abolido poucos dias após a interrupção do tratamento com CLA, conforme mostrado em estudo com infusão abomasal do CLA trans-10 cis-12 (Baumgard et al., 2000). Consistente com a associação negativa entre este CLA e o teor de gordura do leite, a concentração de CLA trans-10 cis-12 no leite foi reduzida após a interrupção do tratamento com CLA (0,06 x 0,02\%). Entretanto, vacas que receberam Lac100 previamente também tiveram menor concentração de CLA trans-10 cis-12 no leite durante o período residual, de forma que a concentração deste CLA no leite dos animais não diferiu entre os tratamentos ao final do período residual (Tabela 10). Neste período, o teor de gordura do leite dos animais de ambos os tratamentos foi menor do que o valor predito de acordo com a equação apresentada na Figura 5. Apesar do alto coeficiente de variação para a concentração do CLA trans-10 cis-12 no leite (Tabelas 6 e 10), estes resultados sugerem que o CLA trans-10 cis-12 não foi, de fato, o único inibidor da síntese de gordura do leite no presente estudo. Grande variação na concentração de CLA no leite tem sido observada mesmo em animais recebendo a mesma dieta (Kelly et al., 1998; Jahreis et al., 1997; Kesley et al., 2002). Segundo Bauman et al. (2003), tais variações podem estar relacionadas à diferenças individuais no que se refere à manutenção da estabilidade do ambiente ruminal ou ainda na atividade da enzima $\Delta-9$ dessaturase.

A concentração do CLA cis-9 trans-11 no leite aumentou após a substituição do CLA por Lac100 (Figura 3), de forma que a concentração deste CLA no leite não diferiu entre tratamentos ao final do período residual (Tabela 
10). Este resultado corrobora a nossa hipótese de que os sais de cálcio de óleo de soja foram dissociados no rúmen dos animais, permitindo uma maior secreção deste CLA no leite.

O fornecimento da dieta com alta proteína aumentou $(P=0,02)$ a concentração de ácido linoléico e reduziu $(P<0,05)$ as concentrações de ácido vaccênico e de CLA cis-9 trans-11 no leite dos animais (Tabelas 9 e 10). Estes resultados são consistentes com aqueles observados durante o período de tratamento (Tabela 5).

Tabela 8. Desempenho e composição do leite dos animais após a substituição do CLA por Lac100 (período residual)

\begin{tabular}{|c|c|c|c|c|c|c|c|}
\hline \multirow[t]{2}{*}{ Parâmetros } & \multicolumn{4}{|c|}{ Tratamentos } & \multirow[t]{2}{*}{ CV (\%) } & \multicolumn{2}{|c|}{$P^{1}$} \\
\hline & $\begin{array}{c}\text { DC + } \\
\text { Lac100 }\end{array}$ & $\begin{array}{l}\mathrm{DC}+ \\
\mathrm{CLA}\end{array}$ & $\begin{array}{l}\text { DAP + } \\
\text { Lac100 }\end{array}$ & $\begin{array}{c}\text { DAP + } \\
\text { CLA }\end{array}$ & & $\mathrm{FL}$ & NPD \\
\hline Produção de leite, $\mathrm{kg} / \mathrm{d}$ & 21,8 & 24,1 & 25,2 & 25,1 & 23,4 & NS & NS \\
\hline $\begin{array}{l}\text { Composição do leite, \% } \\
\text { Gordura }\end{array}$ & 2,63 & 2,69 & 2,81 & 2,63 & 19,9 & NS & NS \\
\hline Proteína & 2,99 & 2,94 & 2,98 & 2,99 & 10,5 & NS & NS \\
\hline Lactose & 4,57 & 4,48 & 4,65 & 4,55 & 5,6 & NS & NS \\
\hline Sólidos totais & 11,1 & 10,9 & 11,5 & 10,9 & 6,7 & NS & NS \\
\hline Prod. dos componentes, & & & & & & & \\
\hline Gordura & 0,59 & 0,65 & 0,71 & 0,69 & 35,8 & NS & NS \\
\hline Proteína & 0,65 & 0,71 & 0,74 & 0,77 & 22,1 & NS & NS \\
\hline Lactose & 1,02 & 1,08 & 1,16 & 1,17 & 22,5 & NS & NS \\
\hline Sólidos totais & 2,50 & 2,60 & 2,88 & 2,82 & 24,1 & NS & NS \\
\hline $\operatorname{CCS}\left[\log _{2}\left(\mathrm{SCC} / 10^{5}\right)+3\right]$ & 1,79 & 3,74 & 4,45 & 3,91 & 76,0 & NS & NS \\
\hline Uréia no leite $(\mathrm{mg} / \mathrm{dl})$ & 31,9 & 34,9 & 39,1 & 37,8 & 20,0 & NS & * \\
\hline Ingestão de MS, kg/d & 16,5 & 16,4 & 16,8 & 16,1 & 15,6 & NS & NS \\
\hline Ingestão de MS, \% PV & 3,6 & 3,4 & 3,5 & 3,3 & 11,5 & NS & NS \\
\hline
\end{tabular}

${ }^{1}$ Efeitos principais (as interações não foram significativas, $P>0,1$ )

FL: Efeito da fonte de lipídio, NPD: Efeito do nível de proteína da dieta

NS: Não significativo $(P>0,1), \dagger P<0,1,{ }^{*} P<0,05,{ }^{*} P<0,01$

DC: Dieta controle, DAP: Dieta com alta proteína

CV: Coeficiente de variação 


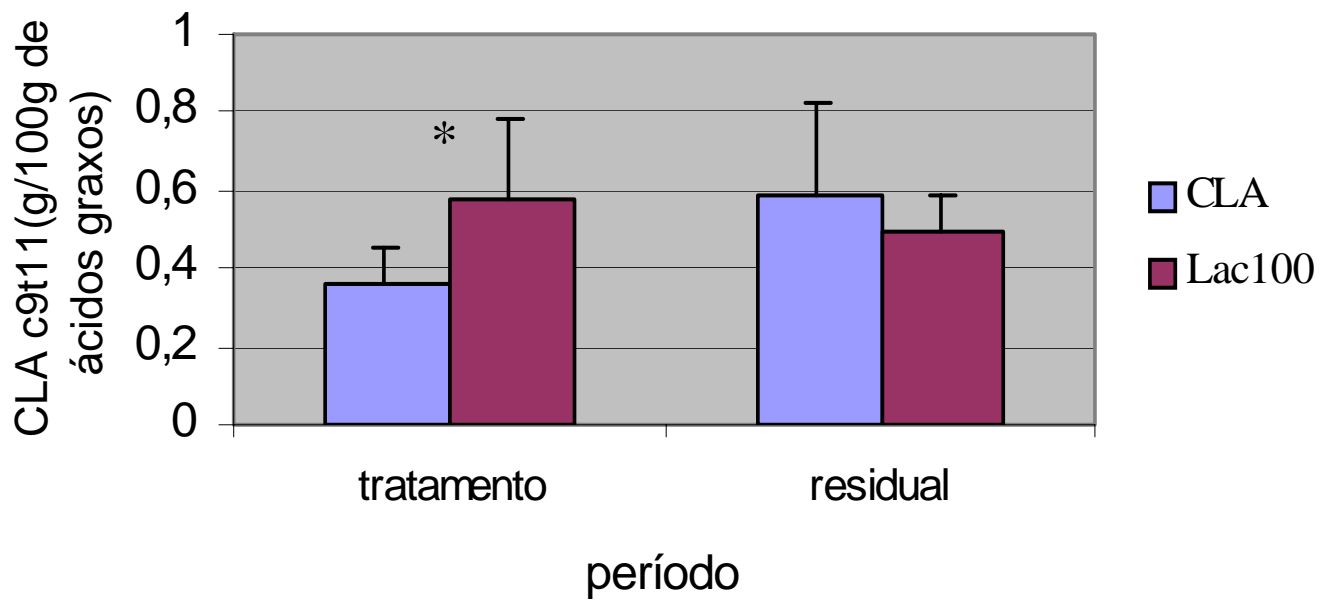

Figura 6 - Concentração de CLA cis-9 trans-11 no leite dos animais antes (período de tratamento) e após a substituição do CLA por Lac100 (período residual). * $\mathrm{P}<0,05$ 
Tabela 9. Concentração de ácidos graxos ( $\mathrm{g} / 100 \mathrm{~g})$ no leite dos animais após a substituição do CLA por Lac100 (período residual)

\begin{tabular}{|c|c|c|c|c|c|c|c|c|}
\hline \multirow[t]{2}{*}{ Ácido graxo } & \multirow[b]{2}{*}{ semana } & \multicolumn{4}{|c|}{ Tratamentos } & \multicolumn{2}{|c|}{$P^{1}$} & \multirow[t]{2}{*}{ CV (\%) } \\
\hline & & $\begin{array}{c}\text { DC + } \\
\text { Lac100 }\end{array}$ & $\begin{array}{l}\mathrm{DC}+ \\
\mathrm{CLA}\end{array}$ & $\begin{array}{l}\text { DAP + } \\
\text { Lac100 }\end{array}$ & $\begin{array}{c}\text { DAP + } \\
\text { CLA }\end{array}$ & $\mathrm{FL}$ & NPD & \\
\hline C4:0 & 7 & 2,92 & 2,89 & 2,98 & 2,97 & NS & NS & 22,0 \\
\hline C6:0 & 7 & 1,45 & 1,52 & 1,59 & 1,57 & NS & NS & 29,0 \\
\hline $\mathrm{C} 8: 0$ & 7 & 0,64 & 0,66 & 0,76 & 0,71 & NS & NS & 40,5 \\
\hline C10:0 & 7 & 1,51 & 1,45 & 1,76 & 1,65 & NS & NS & 40,4 \\
\hline C12:0 & 7 & 1,91 & 1,79 & 2,17 & 1,88 & NS & NS & 32,4 \\
\hline C14:0 & 7 & 7,97 & 7,88 & 8,63 & 7,57 & NS & NS & 19,4 \\
\hline C14:1 c9 & 7 & 0,75 & 0,70 & 0,90 & 0,67 & NS & NS & 37,1 \\
\hline C16:0 & 7 & 25,6 & 25,9 & 27,1 & 26,2 & NS & NS & 10,5 \\
\hline C16:1 c9 & 7 & 1,14 & 1,14 & 1,30 & 1,13 & NS & NS & 21,6 \\
\hline C18:0 & 7 & 14,8 & 13,9 & 13,8 & 15,6 & NS & NS & 15,6 \\
\hline C18:1 c & 7 & 23,2 & 23,1 & 24,2 & 23,0 & NS & NS & 12,4 \\
\hline C18:2 c9c12 & 7 & 1,74 & 1,87 & 2,11 & 2,23 & NS & * & 18,4 \\
\hline C18:3 c9c12c15 & 7 & 0,07 & 0,09 & 0,10 & 0,09 & NS & NS & 41,6 \\
\hline C18:1 t11 & 7 & 5,81 & 6,31 & 4,49 & 5,49 & NS & * & 38,3 \\
\hline
\end{tabular}

${ }^{1}$ Efeitos principais (as interações não foram significativas, $\mathrm{P}>0,1$ )

FL: Efeito da fonte de lipídio, NPD: Efeito do nível de proteína da dieta

NS: Não significativo $(P>0,1), \uparrow P<0,1,{ }^{*} P<0,05$, ${ }^{*} P<0,01$

DC: Dieta controle, DAP: Dieta com alta proteína

CV: Coeficiente de variação 
Tabela 10. Concentração $(\mathrm{g} / 100 \mathrm{~g})$ dos ácidos graxos de cadeias curta (C4C10), média (C12-C16) e longa (C18 total), dos isômeros do CLA e relações entre substrato e produto da enzima $\Delta-9$ dessaturase no leite dos animais durante o período residual

\begin{tabular}{lcccccccc}
\hline Ácido graxo & semana & \multicolumn{9}{c}{ Tratamentos } & \multicolumn{3}{c}{$P^{1}$} & CV (\%) \\
& & $\begin{array}{c}\text { DC }+ \\
\text { Lac100 }\end{array}$ & $\begin{array}{c}\text { DAP }+ \\
\text { CLA }\end{array}$ & $\begin{array}{c}\text { LAc100 } \\
\text { LAP }+\end{array}$ & FL & NPD & \\
\hline C4-C10 & 7 & 6,5 & 6,5 & 7,1 & 6,9 & NS & NS & 27,6 \\
C12-C16 & 7 & 37,2 & 37,4 & 39,2 & 37,5 & NS & NS & 8,8 \\
C18 total & 7 & 47,5 & 47,5 & 46,8 & 48,3 & NS & NS & 9,38 \\
C14:0/14:1c9 & 7 & 11,6 & 12,7 & 9,9 & 13,4 & NS & NS & 35,4 \\
C16:0/16:1c9 & 7 & 23,8 & 23,7 & 21,4 & 24,1 & NS & NS & 20,9 \\
C18:0/18:1c9 & 7 & 0,64 & 0,61 & 0,57 & 0,70 & NS & NS & 22,2 \\
CLA c9t11 & 7 & 0,53 & 0,69 & 0,44 & 0,48 & NS & $*$ & 39,7 \\
CLA t10c12 & 7 & 0,01 & 0,02 & 0,01 & 0,02 & NS & NS & 201,1 \\
\hline
\end{tabular}

${ }^{1}$ Efeitos principais (as interações não foram significativas, $P>0,1$ )

FL: Efeito da fonte de lipídio, NPD: Efeito do nível de proteína da dieta

NS: Não significativo $(P>0,1), \dagger P<0,1,{ }^{*} P<0,05$, ** $P<0,01$

DC: Dieta controle, DAP: Dieta com alta proteína

CV: Coeficiente de variação 


\subsection{Conclusões}

Os animais que receberam CLA encapsulado apresentaram menor teor de gordura do leite do que o grupo controle (Lac100), mas a magnitude desta redução foi inferior a observada em outros estudos. Isto indica que este método de proteção ruminal foi ineficiente, o que é consistente com a baixa concentração de CLA no leite dos animais. Portanto, nossa hipótese sobre o efeito do CLA sobre a síntese de proteína do leite, e a importância de um maior suprimento de proteína através da dieta sobre esta resposta, não puderam ser avaliados.

Os animais que receberam Lac100 apresentaram maior concentração de CLA cis-9 trans-11 e menor concentração de ácido linoléico no leite do que os tratados com CLA, sugerindo que os sais de cálcio de óleo de soja foram amplamente dissociados no rúmen.

A concentração de CLA trans-10 cis-12 no leite foi negativamente associada com o seu teor de gordura, e explicou cerca de $50 \%$ da variação deste componente. Isto sugere que outros fatores afetaram a síntese de gordura do leite.

Visto que a concentração do CLA trans-10 cis-12 aumentou na mesma magnitude após o fornecimento de ambas as fontes lipídicas, o menor teor de gordura do leite observado nos animais que receberam CLA sugere que outros ácidos graxos (naturalmente presentes no produto ou produzidos pela biohidrogenação ruminal destes) foram capazes de inibir a síntese de gordura do leite. 


\section{VARIAÇÃO TEMPORAL DO PERFIL DE ÁCIDOS GRAXO DO LEITE E SUA RELAÇÃO COM A DEPRESSÃO DE GORDURA DO LEITE (DGL) DE VACAS ALIMENTADAS COM DIETAS CONTENDO ÓLEO DE PEIXE E NÍVEIS DISTINTOS DE FIBRA}

\section{Resumo}

Este experimento teve como objetivo principal avaliar os mecanismos envolvidos na depressão da gordura do leite (DGL) de vacas leiteiras recebendo dietas contendo óleo de peixe (OP) e níveis distintos de fibra. Doze vacas

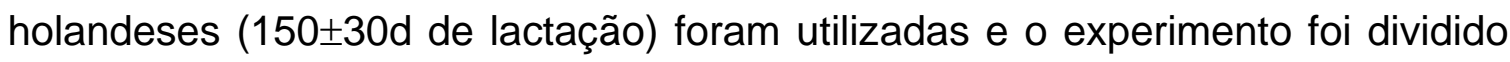
em 3 períodos: 1) Basal: por 12 dias, todos os animais receberam dieta contendo alto teor de fibra, sem óleo de peixe (dieta basal); 2) Suplementação: por 21 dias, grupos de 4 vacas receberam os seguintes tratamentos: a) dieta com alta fibra + óleo de peixe (AF+OP); b) dieta com baixa fibra sem óleo de peixe (BF) e c) dieta com baixa fibra + óleo de peixe (BF+OP); 3) Póssuplementação: os animais voltaram à dieta basal e foram avaliados por 12 dias. As dietas de AF e BF continham cerca de 40 e $26 \%$ de FDN, respectivamente. O único volumoso foi silagem de milho e o OP foi incluído a $1,6 \%$ da MS. A inclusão de OP reduziu $(P<0,05)$ o teor e a secreção de gordura do leite, independentemente do teor de fibra da dieta, mas a magnitude da redução do teor de gordura foi maior na dieta de baixa fibra. A DGL em dietas com OP resultou da menor secreção tanto dos ácidos graxos sintetizados de novo quanto dos pré-formados $(P<0,01)$. Entretanto, o nível de fibra da dieta afetou a 
magnitude destas respostas, com maior e menor secreção dos ácidos graxos de cadeia longa e média $(P<0,1)$, respectivamente, na dieta de baixa fibra. Por outro lado, o fornecimento da dieta BF (sem OP) aumentou $(P<0,1)$ a secreção dos ácidos graxos de cadeia longa no leite, mas não afetou a secreção dos de cadeias curta e média. $O$ fornecimento de OP aumentou $(P<0,01)$ a concentração total de ácidos graxos C18:1trans no leite, sendo este aumento maior $(P<0,05)$ na dieta de baixa fibra. Em contrapartida, o teor de C18:1cis no leite foi menor $(P<0,01)$ nos animais que receberam OP. Este resposta foi, em grande parte, devida a uma redução da concentração de ácido oléico (C18:1c9), consistente com a redução $(P<0,01)$ da concentração do seu precursor, o ácido esteárico (C18:0). A concentração de CLA trans-10 cis-12 no leite aumentou $(P<0,05)$ em resposta ao $O P$, mas sua variação ao longo do tempo não foi consistente com a DGL. Por outro lado, as concentrações de C18:1cis-11 e do CLA trans-9 cis-11 no leite dos animais tratados com OP explicou $\sim 50 \%$ da DGL. A concentração de CLA cis-9 trans-11 no leite aumentou $(P<0,01)$ mais de $300 \%$ acima dos níveis basais em resposta ao OP. $O$ alto $R^{2}(0,85)$ para a regressão entre teores de CLA cis-9 trans-11 e ácido vaccênico (C18:1 trans-11) é consistente com a relação produto/precursor. O componente quadrático da equação sugere que pode haver um limite para incrementos na concentração de CLA cis-9 trans-11 a partir de C18:1 trans-11. Soma-se a isso o menor $(P<0,01)$ índice de atividade da enzima $\Delta-9$ dessaturase nos tratamentos com OP. O fornecimento da dieta BF não afetou $(P>0,1)$ o teor e a secreção de gordura do leite. Consistente com isto, as concentrações de CLA trans-10 cis-12 e C18:1 trans-10 no leite não aumentaram em resposta a este tratamento. Outros componentes do leite também foram afetados pelos tratamentos. O fornecimento da dieta BF aumentou $(P<0,05)$ o teor de proteína do leite, enquanto a inclusão de OP aumentou $(P<0,05)$ o teor de lactose. O consumo de MS dos animais foi reduzido $(P<0,05)$ em resposta ao OP (principalmente na dieta de baixa fibra), mas aumentou $(P<0,05)$ na dieta $B F$ (sem óleo). A produção de leite tendeu $(P<0,1)$ a ser reduzida na dieta $A F+O P$. Nossos resultados sugerem que o CLA 
trans-9 cis-11 e o C18:1 cis-11 podem ser inibidores da síntese de gordura do leite em vacas alimentadas com dietas contendo OP.

\author{
TEMPORAL VARIATION IN MILK FATTY ACIDS PROFILE AND ITS \\ RELATIOSHIP WITH THE MILK FAT DEPRESSION (MFD) OF COWS FED \\ DIETS WITH FISH OIL AND DIFFERENT FIBER LEVELS
}

\title{
Summary
}

The objective of this study was to evaluate the mechanisms involved in milk fat depression (MFD) of dairy cows fed diets with fish oil (FO) and different fiber levels. Twelve Holstein cows (150 $\pm 30 \mathrm{~d}$ post-partum) were used and the study was conducted in three periods: 1) Baseline: for 12 days cows received high fiber diet without FO (baseline diet); 2) Supplementation: 4 cows/group received the following treatments for 21 days: a) High fiber diet + fish oil $(\mathrm{HF}+\mathrm{FO})$, b) Low fiber diet without fish oil (LF) and c) Low fiber diet + fish oil (LF+FO); 3) Post-supplementation: cows returned to the baseline diet and were evaluated for 12 days. HF and LF were 40 and 25\% NDF, respectively. Corn silage was the forage and FO was included at $1.6 \%$ of DM. Milk fat content and yield were reduced $(\mathrm{P}<0.05)$ by $\mathrm{FO}$ treatments, but the magnitude of reduction in milk fat was higher in LF+FO diet. FO-induced MFD resulted in lower $(P<0.01)$ secretion of both de novo and preformed milk fatty acids. However, these responses were affected by dietary fiber. Thus, there were higher and smaller secretion of long and medium chain fatty acids in LF+FO diet, respectively $(P<0.1)$. On the other hand, the LF diet without FO tended $(P<0.1)$ to increase long chain fatty acids secretion, but short and medium fatty acids were unchanged $(P>0.1)$. Concentration of total $C 18$ :1trans increased $(P<0.01)$ in milk 
from cows fed FO, especially in the LF diet $(P<0.05)$. In contrast, concentration of total $\mathrm{C} 18$ :1cis was reduced $(\mathrm{P}<0.01)$ in cows fed FO. Concentration of oleic acid (C18:1c9) accounted for the greatest part of $\mathrm{C} 18: 1$ cis reduction, which is consistent with the low levels of stearic acid (C18:0) in milk from cows fed FO. Concentration of milk trans-10 cis-12CLA increased $(P<0.05)$ in response to FO, but variation was not consistent with MFD. In contrast, concentrations of C18:1cis-11 and CLA trans-9 cis-11 in milk from cows fed FO diets explained $\sim 50 \%$ of MFD. FO increased $(P<0.01)$ concentration of milk cis-9 trans-11 CLA $300 \%$ above baseline. The high $\mathrm{R}^{2}(0.85)$ observed for the regression of cis- 9 trans-11 CLA and vaccenic acid (C18:1 trans-11) is consistent with product:precursor relationship. The quadratic component of this regression suggests a limit to the increase in milk cis-9 trans-11 CLA concentration from C18:1 trans-11. Furthermore, dessaturase activity index was decreased $(P<0.01)$ in response to FO. In contrast to FO treatments, milk fat content and secretion were unchanged $(P>0.1)$ by the LF diet. This is consistent with the lack of trans-10 cis-12 CLA and C18:1 trans-10 increase in milk from cows fed this diet. Other milk components were also affected by treatments. Milk protein and lactose content increased $(P<0.05)$ for $L F$ and FO diets, respectivelly. DMI was reduced $(P<0.05)$ by $F O$ treatments but increased $(P<0.05)$ in reponse to LF diet. Milk production was reduced in $\mathrm{HF}+\mathrm{FO}$ diet $(\mathrm{P}<0.1)$. Our results suggest trans-9 cis-11CLA and C18:1cis-11 could be inhibitors of milk fat synthesis in cows fed FO-supplemented diets.

\subsection{Introdução}

Devido aos efeitos benéficos à saúde atribuídos aos ácidos linoléicos conjugados (CLA), especialmente ao isômero cis-9 trans-11 (Pariza et al., 2001), esforços têm sido feitos para aumentar a concentração destes compostos no leite. A manipulação da dieta de vacas leiteiras através do 
fornecimento de lipídios insaturados tem sido uma das práticas utilizadas para atingir esta meta. Em particular, a inclusão de pequenas quantidades (200$300 \mathrm{~g} / \mathrm{dia}$ ) de óleo de peixe na dieta de vacas em lactação aumenta significativamente (300\% acima dos níveis basais) a concentração de CLA total no leite (Chilliard et al., 2001), sendo este aumento representado quase exclusivamente pelo CLA cis-9 trans-11 (Chilliard et al., 1999; Griinari et al., 2000). Outro aspecto positivo do fornecimento de óleo de peixe é a presença de ácidos graxos poliinsaturados de cadeia longa em sua composição, principalmente o EPA (C20:5 n-3) e o DHA (C22:6 n-3), os quais exercem efeitos benéficos à saúde humana (Daviglus et al., 1997; Wiiliams, 2000). Entretanto, a eficiência de transferência destes compostos da dieta para o leite é geralmente baixa, devido à biohidrogenação ruminal de grande parte destes ácidos graxos (Chilliard et al, 2001). Apesar de baixa, variações nesta eficiência podem ocorrer em função das concentrações de EPA e DHA no rúmen (Gulati et al., 1999; Dohme et al., 2002) e da duração da administração do óleo de peixe (Franklin et al., 1999).

Paralelamente, reduções significativas no teor de gordura no leite têm sido observadas em vacas recebendo óleo de peixe. Embora esta resposta possa ser observada em experimentos com infusão pós-ruminal, as maiores reduções têm sido observadas quando o óleo de peixe é fornecido na dieta dos animais (Chilliard et al., 2001). Isto sugere que o metabolismo do EPA e do DHA no rúmen pode resultar na formação de compostos que inibem a lipogênese na glândula mamária. O aumento da concentração de C18:1 trans10 no leite de vacas alimentadas com dietas contendo óleo de peixe (Griinari et al., 2000) é consistente com a hipótese acima, visto que a formação deste ácido graxo está associada à clássica DGL, proporcionada pela ingestão de dietas com baixo teor de fibra suplementadas com lipídios de origem vegetal (Griinari et al., 1998). Estudos posteriores (Piperova et al., 2000) demonstraram que a DGL observada em tais condições estava também associada a um aumento da concentração do CLA trans-10 cis-12 na gordura do leite. Atualmente, sabe-se 
que este isômero é um potente inibidor da secreção de gordura do leite (Baumgard et al., 2000), reduzindo a atividade de diversas enzimas lipogênicas na glândula mamária (Baumgard et al., 2002).

Por outro lado, a depressão da gordura do leite observada em animais recebendo dietas contendo óleo de peixe não está normalmente associada a um aumento da concentração do CLA trans-10 cis-12 no leite, embora a concentração de C18:1 trans-10 seja também elevada (Griinari et al., 2000; Arola et al., 2002).

Desta forma, outro inibidor (ou inibidores) da secreção de gordura do leite podem estar sendo formados com a ingestão de dietas contendo OP, mas nada se conhece sobre sua identidade até o momento. Da mesma forma, estudos para avaliar a influência de um ambiente ruminal alterado (e.g. baixo pH) sobre a resposta ao OP não têm sido publicados.

Neste sentido, o presente experimento teve como objetivo principal estudar as alterações temporais no padrão de secreção da gordura do leite (com ênfase no perfil de ácidos graxos) de vacas leiteiras quando da inclusão de óleo de peixe em dietas bastante distintas quanto ao teor de fibra.

\subsection{Material e Métodos}

\subsubsection{Animais, instalações e tratamentos}

Doze vacas holandesas, multíparas e em final de lactação (150 \pm 30 dias) foram alojadas em um piquete de cerca de $250 \mathrm{~m}^{2}$, com cochos individuais e portões eletrônicos (CalanGates ${ }^{\circledR}$ ) que permitiam a obtenção do consumo de cada animal.

O experimento todo foi constituído de 3 períodos, conforme descrito abaixo: 
a) Período Basal: durante 12 dias, todos os animais receberam uma que continha alto teor de fibra, sem inclusão de óleo de peixe (Dieta basal). Em seguida, os animais foram blocados pela produção leite e divididos em 3 grupos (4 vacas/grupo), os quais receberam os seguintes tratamentos, por 21 dias (Período de suplementação): 1) dieta com alta fibra + óleo de peixe (AF+OP); 2) dieta com baixa fibra sem a inclusão de óleo de peixe (BF) e 3) dieta com baixa fibra + óleo de peixe (BF+OP); c) Período Pós-suplementação: todos os animais passaram a receber novamente a dieta basal durante os próximos 12 dias, quando então foi encerrado o período experimental.

A mudança da dieta basal (alta fibra sem óleo de peixe) para as dietas de baixa fibra foi realizada gradativamente, com substituição de 25, 50, 75 e 100\% da dieta basal em um período de 4 dias, de forma que no $4^{0}$ dia os animais recebiam $100 \%$ das dietas com baixa fibra. O esquema apresentado abaixo ilustra as três fases do experimento e as respectivas dietas utilizadas:

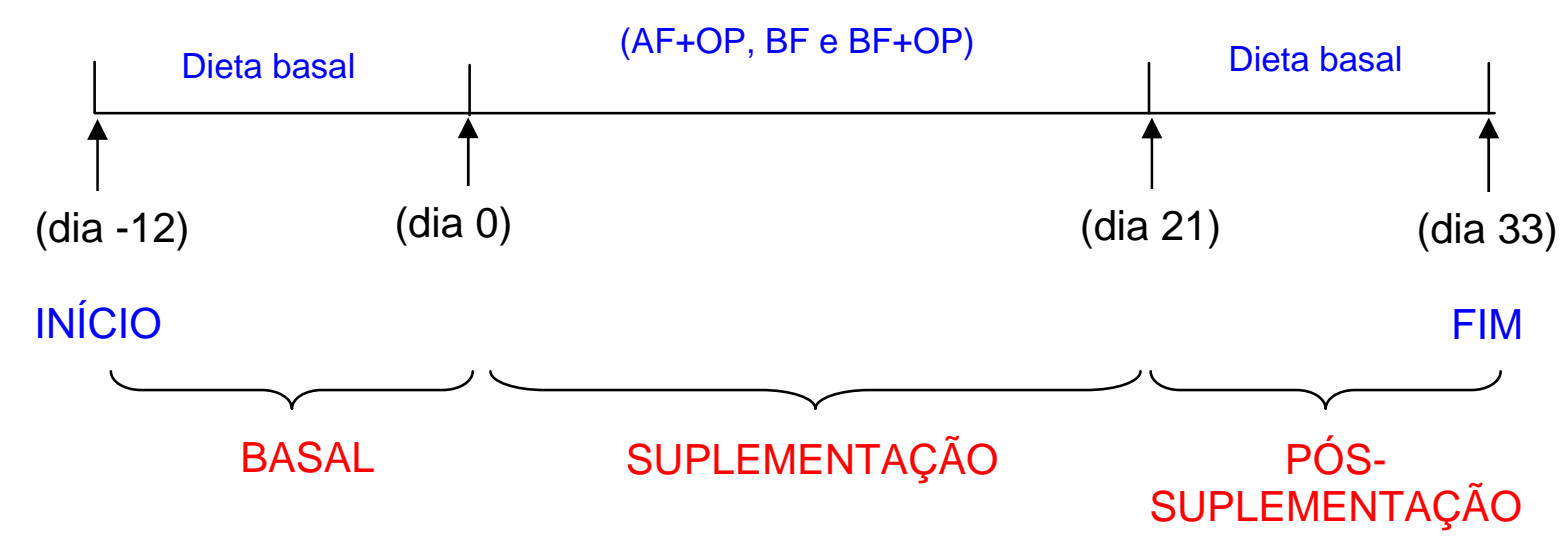

O óleo de peixe foi incluído a 1,6\% da matéria seca das dietas de alta e baixa fibra para permitir um consumo de aproximadamente $250 \mathrm{~g} /$ dia do óleo, de acordo com o consumo de matéria seca estimado pelo Cornell Net 
Carbohydrate and Protein System (CNCPS v.4.1). A composição das dietas experimentais é apresentada na Tabela 1 e o perfil de ácidos graxos das dietas e do óleo de peixe na Tabela 2. Uma amostra do óleo de peixe foi destinada a testes de acidez e rancidez oxidativa (Tabela 3), conforme descrito pela AOCS (1991).

Tabela 1. Proporção dos ingredientes (\% da MS) e composição química das dietas

\begin{tabular}{lcccc}
\hline Ingredientes & \multicolumn{4}{c}{ Dietas } \\
& $\mathrm{AF}$ & $\mathrm{AF}+\mathrm{OP}$ & $\mathrm{BF}$ & $\mathrm{BF}+\mathrm{OP}$ \\
\hline Silagem de milho & 70,1 & 70,1 & 35,2 & 35,1 \\
Milho moído & 6,4 & 3,8 & 41,6 & 40,2 \\
Farelo de Soja & 21,0 & 21,7 & 20,5 & 20,4 \\
Fosfato bicálcico & 0,1 & 0,1 & - & - \\
Calcário & 1,0 & 1,0 & 1,3 & 1,3 \\
Sal (NaCl) & 0,5 & 0,5 & 0,5 & 0,5 \\
Núcleo & 1,0 & 1,0 & 1,0 & 1,0 \\
Óleo de peixe & - & 1,6 & - & 1,6 \\
Composição Química & & & & \\
& & & & \\
FDN (\%) & 39,1 & 40,2 & 26,4 & 25,3 \\
FDA (\%) & 21,4 & 22,5 & 14,0 & 14,3 \\
Lignina (\%) & 3,43 & 3,86 & 3,27 & 2,95 \\
PB (\%) & 16,1 & 16,5 & 17,0 & 16,6 \\
Extrato Etéreo (\%) & 2,28 & 3,31 & 2,77 & 3,97 \\
PB-FDN (\%PB) & 8,74 & 6,97 & 14,94 & 16,6 \\
PB-FDA (\%PB) & 7,41 & 4,81 & 3,41 & 6,14 \\
Ca (\%) & 0,89 & 0,83 & 0,75 & 0,89 \\
P (\%) & 0,35 & 0,36 & 0,41 & 0,38 \\
EL (Mcal/kg MS) & 1,62 & 1,65 & 1,84 & 1,90 \\
\hline AF
\end{tabular}

$\mathrm{AF}=$ alta fibra; $\mathrm{BF}=$ baixa fibra; $\mathrm{OP}=$ óleo de peixe

${ }^{1}$ Óleo de salmão fornecido pela Nutron. 
Tabela 2. Perfil de ácidos graxos das dietas e do óleo de peixe

\begin{tabular}{|c|c|c|c|c|c|c|}
\hline \multirow[t]{2}{*}{ Ácido graxo (\%) } & \multirow[t]{2}{*}{ Representação } & \multirow[t]{2}{*}{$\mathrm{OP}^{1}$} & \multicolumn{4}{|c|}{ DIETAS } \\
\hline & & & $\mathrm{AF}$ & $\mathrm{AF}+\mathrm{OP}$ & $\mathrm{BF}$ & $\mathrm{BF}+\mathrm{OP}$ \\
\hline & & & \multicolumn{4}{|c|}{$\mathrm{g} / 100 \mathrm{~g}$} \\
\hline Caprílico & C8:0 & nd & nd & nd & nd & nd \\
\hline Cáprico & C10:0 & nd & nd & nd & nd & nd \\
\hline Láurico & C12:0 & nd & nd & nd & nd & nd \\
\hline Lauricoléico & C12:1 c9 & nd & nd & nd & nd & nd \\
\hline Mirístico & C14:0 & 6,80 & 0,68 & 1,46 & nd & 3,52 \\
\hline Miristoléico & C14:1 c9 & nd & nd & nd & nd & nd \\
\hline Palmítico & C16:0 & 22,4 & 20,9 & 28,7 & 19,8 & 22,6 \\
\hline Palmitoléico & C16:1 c9 & 9,20 & 0,31 & 0,37 & 0,27 & 4,58 \\
\hline Esteárico & C18:0 & 5,62 & 3,09 & 2,83 & 2,56 & 3,73 \\
\hline Oléico & C18:1 c9 & 31,0 & 25,8 & 23,4 & 28,9 & 29,2 \\
\hline Linoléico & C18:2 c9c12 & 2,49 & 42,8 & 35,3 & 45,2 & 31,4 \\
\hline$\alpha$-Linolênico & C18:3 c9c12c15 & nd & 5,64 & 7,06 & 2,74 & 2,26 \\
\hline Aráquico & C20:0 & 1,00 & 0,34 & 0,36 & 0,30 & 0,20 \\
\hline 11- Eicosenóico & C20:1 c11 & 1,35 & 0,35 & 0,48 & 0,26 & 0,57 \\
\hline Eicosatetraenóico & C20:4 & 0,57 & nd & nd & nd & nd \\
\hline Eicosapentaenóico & C20:5 & 7,48 & nd & nd & nd & nd \\
\hline Behênico & C22:0 & nd & nd & nd & nd & 1,80 \\
\hline Docosahexaenóico & C22:6 & 12,1 & nd & nd & nd & nd \\
\hline
\end{tabular}


Tabela 3. Índices de acidez e rancidez do óleo de peixe utilizado no experimento

\begin{tabular}{lcc}
\hline Análise & Unidade & Valor \\
\hline Índice de rancidez & $\mathrm{mg} \mathrm{NaOH} / \mathrm{g}$ & 3,23 \\
Teste de rancidez & - & positivo \\
Índice de peróxido & $\mathrm{mEq} / 1000 \mathrm{~g}$ de gordura & 38,37 \\
\hline
\end{tabular}

\subsubsection{Coleta de amostras}

Durante todas as fases do experimento, amostras de leite foram coletadas para análise dos seus principais componentes (gordura, proteína, lactose e sólidos totais), contagem de células somáticas (CCS), concentração de uréia e perfil de ácidos graxos. No período basal, as amostras foram coletadas uma semana (dia -7) e 48 horas (dia -2) antes do início do período de suplementação, obtendo-se os valores basais para todos os animais. Durante o período de suplementação, as coletas foram realizadas diariamente para análise dos componentes físico-químicos, enquanto que as amostras destinadas à análise do perfil de ácidos graxos foram coletadas a cada 2 dias durante a transição da dieta de alta fibra para as dietas de baixa fibra (dias 2 e 4) e, então, a cada três dias até o final desta etapa. Este padrão de coleta de amostras (diário para os componentes principais e a cada 3 dias para determinação do perfil de ácidos graxos) foi repetido durante a última etapa do período experimental (pós-suplementação).

4.2.3 Avaliação do consumo, escore corporal (ECC), peso vivo e produção de leite. 
O consumo dos animais foi obtido diariamente descontando-se das sobras pesadas antes da ordenha da manhã, a quantidade de alimento oferecido nos dois turnos (manhã e tarde). Todas as dietas foram fornecidas na forma de mistura completa, na qual os concentrados, contendo ou não óleo de peixe, foram misturados à silagem de milho na proporção apropriada a cada dieta. O registro do consumo individual foi possível devido à utilização do sistema CalanGates ${ }^{\circledR}$, no qual os animais recebiam um colar com um sensor eletrônico que permitia acesso a somente um único cocho. O início do experimento só se deu após a adaptação plena dos animais a este sistema.

A avaliação do escore corporal (escala de 1 a 5) e do peso vivo foi realizada no final de cada período do experimento (dias 12, 33 e 45). As produções de leite foram registradas diariamente, sendo os dados obtidos no período basal utilizados para formação dos blocos.

\subsubsection{Análises laboratoriais}

Os componentes físico-químicos do leite foram determinados por infravermelho, utilizando-se o aparelho BENTLEY 2000. A concentração de uréia no leite foi determinada por colorimetria e expressa em $\mathrm{mg} / \mathrm{dL}$.

A gordura do leite foi extraída por uma mistura de solventes orgânicos (hexano:isopropanol), conforme descrito por Hara \& Radim (1978).

Para a metilação ou transesterificação dos ácidos graxos, foi utilizada uma solução básica de metóxido de sódio (Christie, 1982). Este procedimento de metilação (utilizando soluções básicas) tem sido preferencialmente utilizado, pois catálises ácidas podem resultar na isomerização dos CLAs de configuração cis-trans ou trans-cis para configurações do tipo trans-trans (Kramer et al., 1997).

O perfil de ácidos graxos do leite foi determinado por cromatografia gasosa (cromatógrafo modelo Agilent 6890), utilizando-se uma coluna capilar 
de $200 \mathrm{~m} \times$ 0,25mm de sílica fundida (CP7421-Varian) e detector de ionização de chama (FID). As temperaturas do injetor e do detector foram de 240 e $250^{\circ} \mathrm{C}$, respectivamente. Utilizou-se hidrogênio como gás de arraste a um fluxo constante de 1,2 $\mathrm{ml} / \mathrm{min}$ e a razão de injeção das amostras foi de 50:1. A temperatura inicial da corrida foi de $80^{\circ} \mathrm{C}$. Três minutos após a injeção da amostra, a temperatura foi elevada a $10^{\circ} \mathrm{C} / \mathrm{min}$ até atingir $165^{\circ} \mathrm{C}$, onde manteve-se por 5 min. Em seguida, a temperatura foi novamente elevada a $0,3^{\circ} \mathrm{C} / \mathrm{min}$ até $195^{\circ} \mathrm{C}$ e mantida por $2 \mathrm{~min}$. Seguiu-se um novo aumento de temperatura a $2^{\circ} \mathrm{C} / \mathrm{min}$ até atingir $240^{\circ} \mathrm{C}$ (mantida por $10 \mathrm{~min}$ ) e finalmente a $4^{\circ} \mathrm{C} / \mathrm{min}$ até $280^{\circ} \mathrm{C}$, mantida por 10 min até o final da corrida.

A identificação dos ácidos graxos das amostras foi realizada através de comparação dos seus tempos de retenção com os observados em padrões comerciais de manteiga (CRM 164; Commission of the European Communities, Community Bureau of Reference, Brussels, Belgium) e de CLA (padrão de CLA). A manteiga padrão foi também utilizada para determinar os fatores de recuperação para os ácidos graxos, especialmente os de cadeia curta, cujas perdas podem ser elevadas durante a injeção das amostras.

Para a determinação do perfil de ácidos graxos dos alimentos, a fração lipídica das amostras foi extraída com hexano por $2 \mathrm{~h}$ a $85^{\circ} \mathrm{C}$, utilizando o sistema Sohlext (refluxo). Em seguida, os lipídios foram metilados utilizando solução de metanol em meio ácido ( $10 \%$ de ácido sulfúrico), conforme determinado pela AOCS (1991). O perfil de ácidos graxos foi determinado em cromatógrafo gasoso (modelo Varian 3400), utilizando-se a coluna capilar LM$100(60 \mathrm{~m} \times 0,25 \mathrm{~mm} \times 1 \mu \mathrm{m})$, hidrogênio como gás de arraste $(1 \mathrm{~mL} / \mathrm{min})$ e detector de ionização de chama (FID). As temperaturas do injetor e do detector foram de 220 e $240^{\circ} \mathrm{C}$, respectivamente. As amostras foram injetadas na razão de 20:1, e a temperatura durante a corrida variou de 70 a $230^{\circ} \mathrm{C}$, elevando-se a uma taxa de $4^{\circ} \mathrm{C} / \mathrm{min}$. Padrões comerciais de ácidos graxos purificados (Sigma Diagnostics, PA) foram utilizados para identificação dos ácidos graxos das amostras analisadas. 
4.2.5 Análise estatística

Os dados foram analisados através do programa computacional Statistical Analysis System (SAS Institute Inc., 2000). Dois tipos de análise dos efeitos de tratamento foram realizadas, em função da disposição dos tratamentos ao longo do período experimental. Na primeira, as respostas aos tratamentos aplicados concomitantemente (dieta AF+OP $x$ dieta BF $x$ dieta $\mathrm{BF}+\mathrm{OP}$ ) foram comparadas entre si através do procedimento GLM, utilizandose as médias obtidas na terceira semana como variável resposta e os dados obtidos na semana anterior ao início dos tratamentos (PERÍODO BASAL) como covariável. A segunda análise envolveu o estudo das respostas obtidas na terceira semana após o início de cada tratamento (PERÍODO DE SUPLEMENTAÇÃO) em relação aos seus valores iniciais correspondentes (PERÍODO BASAL). Neste caso, os efeitos de tratamentos foram avaliados por testes paramétricos ou não paramétricos, em função dos resultados obtidos para normalidade dos resíduos (Teste de Shapiro-Wilk) e simetria da distribuição (valores de Skewness). As análises de regressão foram feitas através do procedimento GUIDED DATA ANALYSIS do SAS.

Embora se tenha adotado um nível de significância de 5\% para todos os testes realizados, considerou-se que um determinado efeito tendeu a ocorrer quando $\mathrm{P}<0,1$.

\subsection{Resultados e Discussão}

4.3.1 Desempenho, composição do leite e consumo de matéria seca (MS)

Devido à impossibilidade de mantermos um grupo recebendo a dieta basal durante o período de suplementação, o efeito de interação entre óleo e nível de fibra não pôde ser apropriadamente avaliado neste experimento. Desta forma, 
os tratamentos fornecidos durante o período de suplementação foram comparados entre si (Tabelas 4 e 6 ) e com os valores obtidos para o mesmo grupo de animais na fase anterior, quando todos os animais recebiam a dieta basal (Tabelas 5 e 7 ).

Os resultados referentes à composição e produção dos componentes do leite são apresentados nas Tabelas 4 e 5, e os referentes ao consumo de MS e peso vivo dos animais nas Tabelas 6 e 7.

Tabela 4. Médias corrigidas da produção e composição do leite dos animais em resposta aos tratamentos AF+OP (1), BF (2) e BF+OP (3)

\begin{tabular}{lcccccccc}
\hline Variáveis & \multicolumn{3}{c}{ Tratamentos } & EPM & \multicolumn{3}{c}{ Contrastes $^{\mathrm{a}}$} \\
& $\mathrm{AF}+\mathrm{OP}$ & $\mathrm{BF}$ & $\mathrm{BF}+\mathrm{OP}$ & & $1 \times 2$ & $1 \times 3$ & $2 \times 3$ \\
\hline Produção de leite, kg/d & 15,4 & 19,7 & 17,8 & 1,19 & $\dagger$ & $\mathrm{NS}$ & $\mathrm{NS}$ \\
Teor de gordura, \% & 2,85 & 3,86 & 2,62 & 0,24 & $*$ & $\mathrm{NS}$ & $*$ \\
Prod. de gordura, kg/d & 0,45 & 0,73 & 0,44 & 0,06 & $* \star$ & $\mathrm{NS}$ & $* *$ \\
Teor de proteína, \% & 3,13 & 3,32 & 3,12 & 0,12 & $\dagger$ & $\mathrm{NS}$ & $\dagger$ \\
Prod. de proteína, kg/d & 0,49 & 0,66 & 0,53 & 0,05 & $*$ & $\mathrm{NS}$ & $\dagger$ \\
Teor de lactose, \% & 4,85 & 4,76 & 4,93 & 0,07 & $\mathrm{NS}$ & $\mathrm{NS}$ & $\mathrm{NS}$ \\
Prod. de lactose, $\mathrm{kg} / \mathrm{d}$ & 0,77 & 0,95 & 0,84 & 0,06 & $\dagger$ & $\mathrm{NS}$ & $\mathrm{NS}$ \\
N-uréia no leite, $\mathrm{mg} / \mathrm{dL}$ & 17,9 & 16,2 & 15,0 & 0,76 & $\mathrm{NS}$ & $\mathrm{NS}$ & $\mathrm{NS}$ \\
\hline
\end{tabular}

EPM = Erro padrão da média; $\mathrm{AF}=$ Alta Fibra; $\mathrm{BF}=$ Baixa Fibra; $\mathrm{OP}$ = Óleo de peixe ${ }^{a}$ Probabilidades das diferenças entre os tratamentos

NS = Não significativo $(P>0,1) \dagger P<0,1 * P<0,05$ ** $P<0,01$ 
Reduções no teor de gordura do leite têm sido freqüentemente observadas em rebanhos comerciais onde os animais recebem dietas que ocasionam abaixamento do $\mathrm{pH}$ ruminal (e.g. dietas com baixo teor de fibra, fibra de baixa efetividade física, excesso de amido, etc.), e esta situação é geralmente referida como depressão da gordura do leite ou DGL (Bauman \& Griinari, 2001). No presente experimento, embora o pH ruminal não tenha sido medido diretamente, o baixo teor de FDN das dietas com baixa fibra (cerca de $26 \%$ de FDN, Tabela 1) e a utilização de silagem de milho como fonte exclusiva de volumoso sugerem que o $\mathrm{pH}$ ruminal tenha sido bastante reduzido em tais condições. Soma-se a isto a observação de que as fezes dos animais apresentavam-se excessivamente moles, um sinal conhecido de deficiência de fibra na dieta. Entretanto, ao contrário do que se previa, o fornecimento deste tipo de dieta sem a inclusão de óleo de peixe (dieta BF) não resultou em redução no teor de gordura do leite dos animais (Tabelas 4 e 5), sendo esta resposta bastante consistente ao longo de todo o período de fornecimento desta dieta (Figura 1).

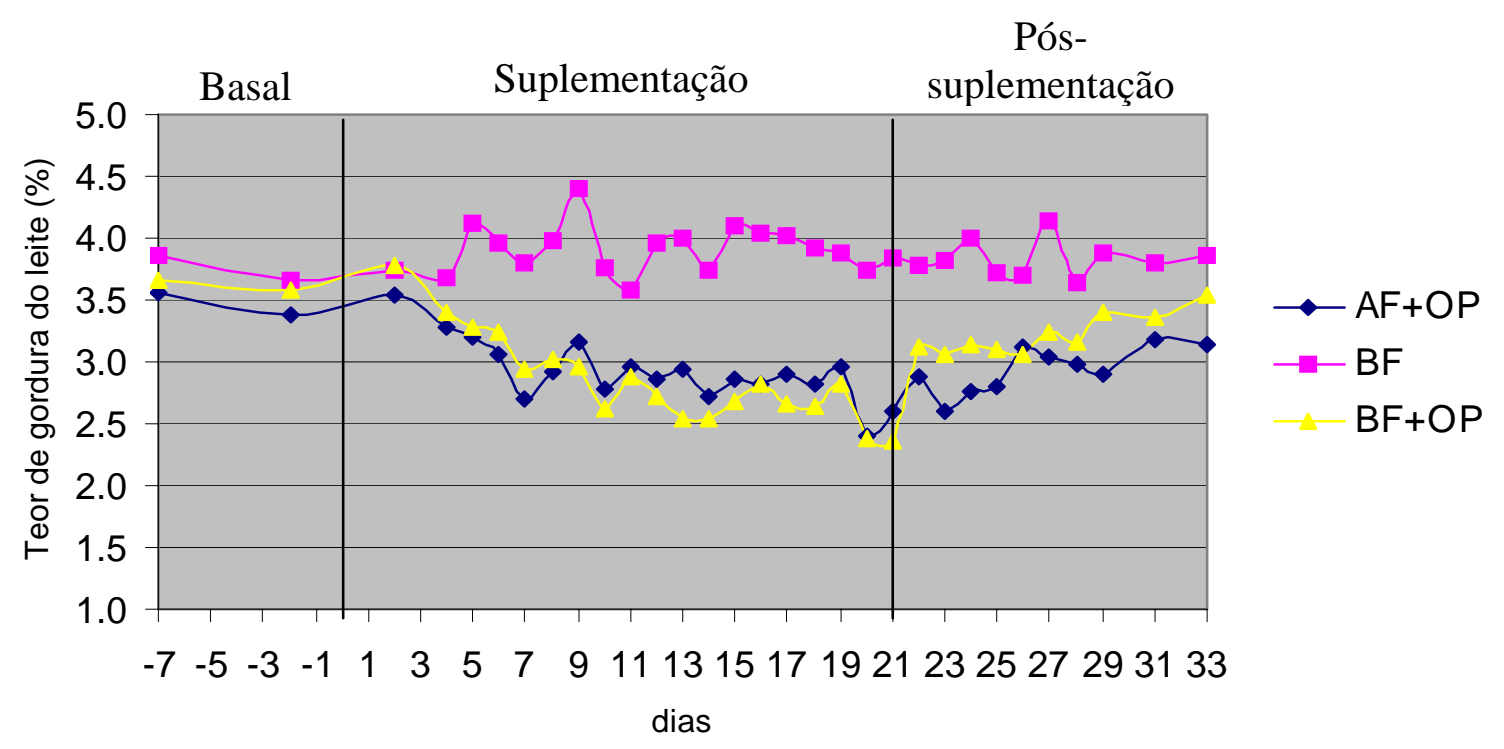

Figura 1 - Teor de gordura do leite dos animais durante todo o período experimental 
Experimento conduzido por Griinari et al. (1998) representa um marco importante para o entendimento do mecanismo da DGL, e suas conclusões parecem justificar as respostas observadas neste experimento. Estes pesquisadores demostraram que duas condições são necessárias para que ocorra a DGL: um baixo $\mathrm{pH}$ ruminal e a presença de lipídios insaturados na dieta. De particular importância, este experimento mostrou ainda que a ampla redução no teor de gordura do leite observada quando ambas as condições estavam presentes, estava associada a um aumento significativo na concentração de isômeros C18:1 trans-10 na gordura do leite. Em trabalhos subseqüentes, foi demostrado que a DGL está associada também a um aumento na concentração do CLA trans-10 cis-12 (Piperova et al., 2000; Offer et al., 2001). Ambos os ácidos graxos são formados no rúmen através da biohidrogenação do ácido linoléico presente na dieta (Kim et al., 2002). Estudos com infusão abomasal do CLA trans-10 cis-12 comprovaram a potente ação anti-lipogênica deste isômero na glândula mamária, o qual é capaz de reduzir significativamente a secreção de gordura do leite mesmo quando fornecido em pequenas quantidades (Baumgard et al., 2000; Peterson et al., 2002). O mecanismo de ação deste CLA é explicado em grande parte por uma redução na atividade de enzimas envolvidas na síntese de novo de ácidos graxos na glândula mamária (Piperova et al., 2000; Hayashi et al., 2002), embora outras enzimas envolvidas na síntese de lipídios também sejam afetadas (Baumgard et al., 2002).

As informações apresentadas acima indicam que, embora o tratamento $\mathrm{BF}$ no presente experimento tenha provavelmente induzido uma queda no $\mathrm{pH}$ ruminal, a baixa concentração de lipídios poliinsaturados (neste caso formados quase exclusivamente pelo ácido linoléico) nesta dieta (cerca de $10,5 \mathrm{~g} / \mathrm{kg}$ de MS) não permitiu uma redução no teor e na secreção de gordura do leite. Em outras palavras, é provável que não tenha havido substrato o suficiente para que as bactérias ruminais formassem, pelo processo de biohidrogenação, o 
CLA trans-10 cis-12 ou metabólitos associados (e.g. C18:1 trans-10), os quais reduziriam a secreção de gordura do leite. De fato, os resultados do perfil de ácidos graxos da gordura do leite (ver item 3.2) confirmaram a suposição acima.

Além do efeito inibitório direto de ácidos graxos específicos produzidos no rúmen, outros mecanismos têm sido propostos para explicar a DGL.

Dietas com alto teor de grãos, como no caso da dieta BF, resultam em aumento da produção de ácido propiônico, no rúmen (Sutton, 1985), promovendo maior produção de glicose (via gliconeogênica) e, por conseqüência, maior liberação de insulina. $O$ aumento da concentração de insulina poderia reduzir o teor de gordura do leite por diminuir o aporte de substratos para a síntese de lipídios, na glândula mamária, uma vez que este hormônio estimula a lipogênese e inibe a lipólise no tecido adiposo (Bauman, 2000). Estudos onde a insulina foi aumentada de 4 a 5 vezes acima dos níveis basais (mantendo-se a glicemia constante) mostraram que a redução na secreção de gordura do leite foi mínima quando os animais estavam em balanço energético positivo, mas considerável (cerca de 35\%) quando vacas em início de lactação foram utilizadas (Bauman \& Griinari, 2001; Bauman \& Griinari, 2003). Neste último caso, foi observada uma redução na concentração plasmática de ácidos graxos não-esterificados, indicando uma redução da lipólise em resposta à insulina. A menor concentração de ácidos graxos de cadeia longa observada no leite dos animais (Bauman \& Griinari, 2001) é consistente com o mecanismo de inibição proposto acima.

Estes dados indicam que a ausência de depressão da gordura do leite observada no presente experimento em resposta ao fornecimento da dieta BF pode ser também justificada pelo estágio avançado da lactação em que se encontravam os animais, uma vez que, nesta situação, apenas 4 a $8 \%$ dos ácidos graxos secretados no leite são oriundos dos ácidos graxos pré-formados provenientes da mobilização das reservas de gordura corporal (Palmquist \& Mattos, 1978). 
Diferentemente do observado para a dieta BF, o fornecimento de óleo de peixe reduziu $(P<0,05$, Tabelas 4 e 5$)$ o teor de gordura do leite dos animais, independentemente do teor de fibra da dieta. Esta redução ocorreu gradativamente, atingindo os menores valores na última semana de tratamento (Figura 1).

Reduções de 0,9 a 1,6 unidades percentuais no teor de gordura do leite têm sido observadas em resposta ao fornecimento de dietas contendo óleo de peixe em diversos experimentos, nos quais foram administrados 180 a 450 g/dia de óleo (Chilliard et al., 2001). Além disso, ao contrário do que se observa em dietas contendo fontes de lipídios insaturados de origem vegetal, tais respostas têm sido observadas mesmo em dietas contendo níveis adequados de fibra (Chilliard et al., 1999; Offer et al., 1999).

Este efeito pode ser claramente evidenciado neste experimento, uma vez que o teor de gordura do leite foi progressivamente reduzido após o início do fornecimento da dieta AF+OP (Figura 1). Esta resposta pode ser melhor vista, em termos numéricos, nos dados apresentados na Tabela 5, onde o efeito da inclusão do óleo foi avaliado em comparação com os valores obtidos para os mesmos animais antes do início da suplementação (PERÍODO BASAL). Os dados apresentados nesta tabela mostram ainda que a magnitude da redução no teor de gordura do leite foi maior nos animais que receberam OP em associação a uma dieta com baixa fibra (-1,01 x 0,70 unidades percentuais), embora não tenha havido diferença estatística entre estas dietas (Tabela 4). Estes dados indicam que a redução do teor de gordura do leite causada pela adição de OP pode ser ainda maior em condições de baixo $\mathrm{pH}$ ruminal, embora este experimento não tenha permitido estudar apropriadamente o efeito de interação entre o nível de fibra e a presença de OP na dieta.

O mecanismo pelo qual o óleo de peixe inibe a secreção de gordura do leite é pouco conhecido. Estes óleos são ricos em ácidos graxos poliinsaturados de cadeia longa, dos quais o EPA (C20:5 n-3) e o DHA (C22:6 n-3) são os mais importantes (Givens et al., 2000). Neste experimento, as 
concentrações destes ácidos graxos no OP foram de 7,5 e 12\%, respectivamente (Tabela 2), valores muito próximos aos relatados por Whitlock et al. (2002). Entretanto, é importante destacar que estas concentrações podem variar amplamente em função da espécie de peixe utilizada para obtenção do óleo, tendo-se obtidos valores de 4 a 32\% para EPA e de 2 a $25 \%$ para DHA (Moffat \& McGill, 1993). Além disso, estes ácidos graxos poliinsaturados são altamente susceptíveis à peroxidação, o que pôde ser evidenciado pelo alto índice de peróxido mostrado na Tabela 3. Uma vez que o processo de oxidação é catalisado pela presença do oxigênio e de determinados metais como o cobre e o zinco, a mistura deste óleo aos demais ingredientes dos concentrados só foi realizada imediatamente antes do período de suplementação. Embora a infusão pós-ruminal de OP possa reduzir a secreção da gordura do leite, as maiores respostas têm sido observadas em experimentos onde o óleo de peixe foi incluído na dieta dos animais (Chilliard et al., 2001). A baixa eficiência de transferência destes compostos da dieta para o leite (média de 2,6\% e 4,1\% para EPA e DHA, respectivamente) indicam uma biohidrogenação ruminal de grande parte destes ácidos graxos (Chilliard et al, 2001), embora o grau de biohidrogenação possa variar em função das concentrações de EPA e de DHA no rúmen (Gulati et al., 1999; Dohme et al., 2002) e da duração da administração do óleo de peixe, visto que os microorganismos ruminais necessitam de algum tempo para se adaptarem à presença do óleo (Franklin et al., 1999). Estes dados sugerem que os ácidos graxos poliinsaturados de cadeia longa presentes no óleo de peixe (ou mais provavelmente os intermediários da biohidrogenação destes compostos) podem estar envolvidos, direta ou indiretamente, na inibição da lipogênese na glândula mamária. Uma inibição indireta envolveria a formação, devido à presença de OP no rúmen, de intermediários da biohidrogenação de outros ácidos graxos presentes na dieta basal (e.g. ácidos linoléico e $\alpha$-linolênico), visto que o OP apresenta, geralmente, somente quantidades mínimas destes ácidos graxos (Tabela 2). Esta hipótese é reforçada pelo aumento significativo 
da concentração de C18:1 trans-10 no leite de vacas alimentadas com dietas contendo óleo de peixe e que apresentaram DGL (Griinari et al., 2000), embora o efeito inibitório deste metabólito sobre a secreção de gordura do leite não tenha sido determinado experimentalmente devido à dificuldade de se obter fontes purificadas deste composto. O ácido graxo C18:1 trans-10 é um produto resultante da biohidrogenação do CLA trans-10 cis-12 pelas bactérias ruminais (Kepler et al., 1966), que por sua vez pode ser formado a partir da isomerização do ácido linoléico (Kim et al., 2002). No entanto, ao contrário do que se observa em resposta ao fornecimento de dietas contendo baixo teor de fibra suplementadas com lipídios de origem vegetal (e.g. óleo de soja), a DGL em vacas recebendo OP não está associada a uma aumento da concentração do CLA trans-10 cis-12 (Griinari et al., 2000). Isto sugere que a via (ou as vias) de formação do C18:1 trans-10 no rúmen de animais recebendo OP podem não envolver, necessariamente, a formação do CLA trans-10 cis-12 como intermediário. Como o CLA trans-10 cis-12 é o único inibidor da síntese de gordura do leite identificado até o momento, a DGL observada em vacas alimentadas com dietas contendo OP envolve, claramente, a formação de outro inibidor (ou inibidores), supostamente intermediários da biohidrogenação ruminal de ácidos graxos poliinsaturados presentes na dieta. A identificação de tal metabólito (ou metabólitos), bem como a compreensão do seu mecanismo de ação, são de grande interesse, mas permanecem ainda desconhecidos. Procurando avançar neste sentido, o presente experimento buscou avaliar as alterações temporais no perfil de ácidos graxos e no teor de gordura do leite em resposta ao fornecimento de OP, em dietas contendo níveis distintos de fibra. Os resultados obtidos indicam que outros isômeros (além do C18:1 trans10) são especialmente relacionados à $D G L$ de vacas que receberam dietas contendo OP. Tais resultados são apresentados e discutidos em detalhes no item 3.2. 
Tabela 5. Diferenças entre a produção e a composição do leite dos animais durante o período de suplementação (S) em relação aos valores observados previamente durante o período basal (B)

\begin{tabular}{|c|c|c|c|c|c|c|}
\hline \multirow[t]{2}{*}{ Variável } & \multirow[t]{2}{*}{ Tratamento } & \multicolumn{3}{|c|}{ Período } & \multirow[t]{2}{*}{ EPM } & \multirow[t]{2}{*}{$P$} \\
\hline & & B & S & S-B & & \\
\hline & $A F+O P$ & 18,2 & 15,4 & $-2,80$ & 0,98 & $\dagger$ \\
\hline \multirow{3}{*}{ Produção de leite, $\mathrm{kg} / \mathrm{d}$} & $\mathrm{BF}$ & 18,2 & 19,7 & $+1,53$ & 0,99 & NS \\
\hline & $\mathrm{BF}+\mathrm{OP}$ & 19,3 & 17,8 & $-1,48$ & 1,58 & NS \\
\hline & $\mathrm{AF}+\mathrm{OP}$ & 3,47 & 2,77 & $-0,70$ & 0,16 & * \\
\hline \multirow[t]{3}{*}{ Teor de gordura, \% } & $\mathrm{BF}$ & 3,77 & 3,94 & $+0,17$ & 0,30 & NS \\
\hline & $\mathrm{BF}+\mathrm{OP}$ & 3,63 & 2,62 & $-1,01$ & 0,31 & * \\
\hline & $A F+O P$ & 0,62 & 0,40 & $-0,22$ & 0,03 & ** \\
\hline \multirow[t]{3}{*}{ Prod. de gordura, kg/d } & $\mathrm{BF}$ & 0,70 & 0,77 & $+0,07$ & 0,05 & NS \\
\hline & $\mathrm{BF}+\mathrm{OP}$ & 0,69 & 0,47 & $-0,22$ & 0,02 & ** \\
\hline & $A F+O P$ & 3,22 & 3,12 & $-0,10$ & 0,07 & NS \\
\hline \multirow[t]{3}{*}{ Teor de proteína, \% } & $\mathrm{BF}$ & 3,32 & 3,42 & $+0,10$ & 0,03 & * \\
\hline & $\mathrm{BF}+\mathrm{OP}$ & 3,15 & 3,03 & $-0,13$ & 0,08 & NS \\
\hline & $A F+O P$ & 0,58 & 0,47 & $-0,11$ & 0,03 & * \\
\hline \multirow[t]{3}{*}{ Prod. de proteína, kg/d } & $\mathrm{BF}$ & 0,60 & 0,67 & $+0,07$ & 0,04 & NS \\
\hline & $\mathrm{BF}+\mathrm{OP}$ & 0,60 & 0,54 & $-0,06$ & 0,06 & NS \\
\hline & $\mathrm{AF}+\mathrm{OP}$ & 4,52 & 4,79 & $+0,27$ & 0,05 & * \\
\hline \multirow[t]{3}{*}{ Teor de lactose, $\%$} & $\mathrm{BF}$ & 4,73 & 4,92 & $+0,19$ & 0,07 & $\dagger$ \\
\hline & $\mathrm{BF}+\mathrm{OP}$ & 4,50 & 4,84 & $+0,35$ & 0,10 & * \\
\hline & $\mathrm{AF}+\mathrm{OP}$ & 0,83 & 0,74 & $-0,08$ & 0,05 & NS \\
\hline \multirow[t]{2}{*}{ Prod. de lactose, $\mathrm{kg} / \mathrm{dia}$} & $\mathrm{BF}$ & 0,86 & 0,97 & $+0,11$ & 0,03 & $\dagger$ \\
\hline & $\mathrm{BF}+\mathrm{OP}$ & 0,86 & 0,86 & 0 & 0,07 & NS \\
\hline
\end{tabular}

$\mathrm{AF}=$ Alta Fibra; $\mathrm{BF}=$ Baixa Fibra; OP = Óleo de Peixe

EPM = Erro padrão da média das diferenças (S-B).

DIF (S-B) = Diferenças entre as médias obtidas na $3^{\text {a }}$ semana do período de suplementação e as obtidas no período basal (B).

NS = Não significativo $(P>0,1)$.

${ }^{*} \mathrm{P}<0,05$ ** $\mathrm{P}<0,01$ 
A produção de leite dos animais aumentou logo após o fornecimento das dietas com baixa fibra, mas foi amplamente reduzida no grupo $\mathrm{BF}+\mathrm{OP}$ do $7^{\circ}$ ao $11^{\circ}$ dia de tratamento, quando então se manteve praticamente constante até o final do período de suplementação (Figura 2). Por outro lado, a produção de leite dos animais tratados com a dieta de baixa fibra, sem a inclusão de óleo (BF), manteve-se mais elevada durante este mesmo período. Diferentemente, a produção de leite em resposta ao tratamento AF+OP foi progressivamente reduzida após o início do tratamento, estabilizando-se na última semana. Como conseqüência, a produção de leite dos animais que receberam esta dieta tendeu $(P=0,06)$ a ser inferior à observada nos mesmos animais durante 0 fornecimento da dieta basal (Tabela 5). Além disso, após a estabilização das respostas, este grupo tendeu $(P=0,06)$ a apresentar uma menor produção de leite do que animais que receberam a dieta com baixa fibra sem a inclusão de óleo (Tabela 4). O grupo BF+OP apresentou produção de leite intermediária, não diferindo estatisticamente dos demais grupos.

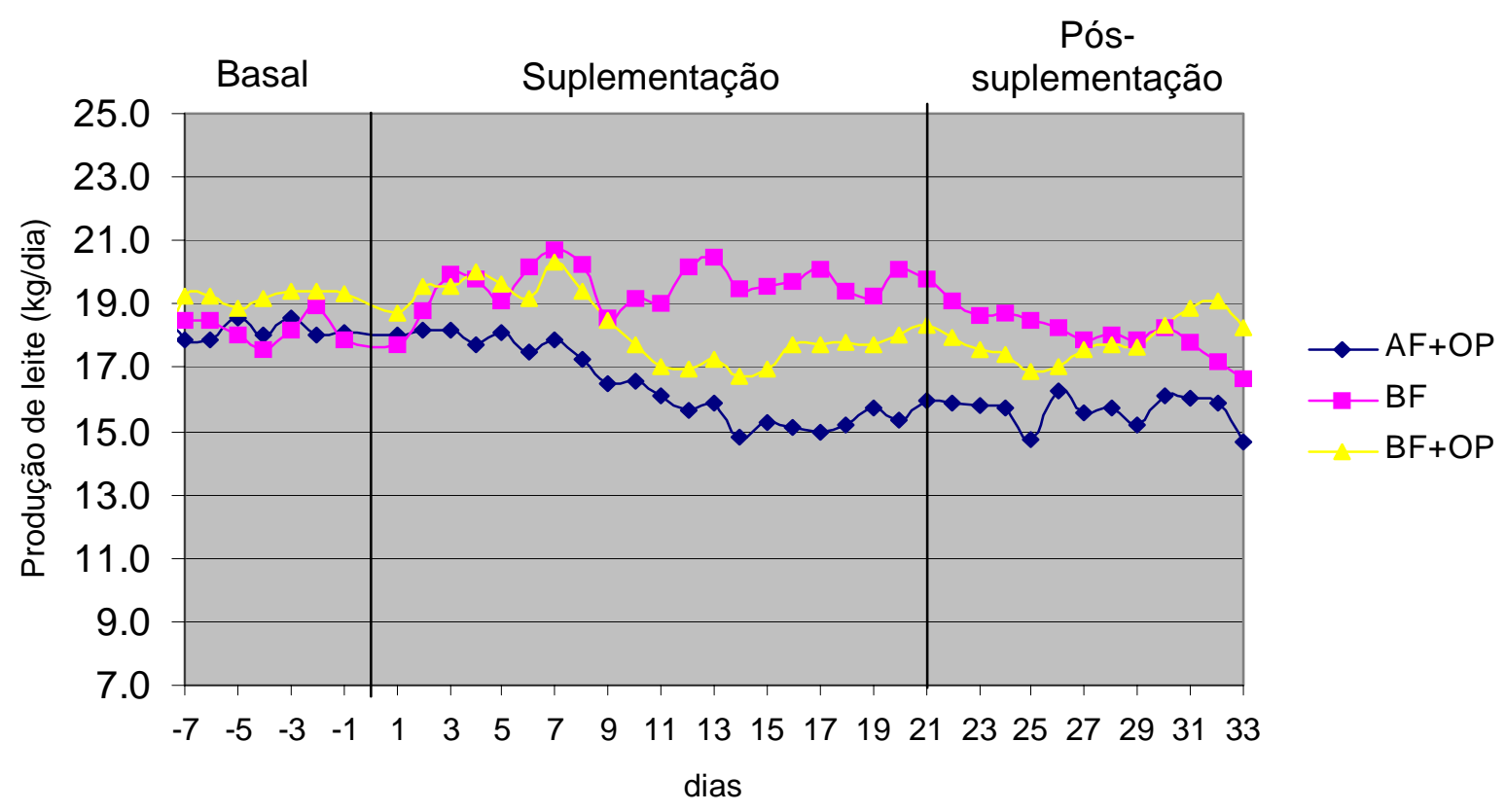

Figura 2 - Produção de leite dos animais durante todo o período experimental 
Embora a redução na produção de leite dos animais que receberam OP tenha sido maior na dieta com alto teor de fibra (-2,8 $x-1,5 \mathrm{~kg} / \mathrm{dia}$, Tabela 5), a produção de gordura do leite foi muito semelhante em ambos os tratamentos (Tabela 4), pois a redução no teor de gordura do leite foi maior quando o óleo foi fornecido em associação à dieta com baixo teor de fibra $(-1,01 \times-0,70$ unidades percentuais, Tabela 5). Em conseqüência destas alterações, a secreção diária de gordura foi significativamente reduzida $(P<0,01)$ nos animais que receberam óleo de peixe, independentemente do teor de fibra da dieta (Tabelas 4 e 5).

Reduções na secreção de gordura do leite também foram observadas quando quantidades semelhantes de óleo de peixe foram incluídas na dieta de vacas (Cant et al., 1996; Shingfield et al., 2003; Arola et al., 2003) ou de cabras em lactação (Gulati et al., 1999). Em geral, assim como o observado neste experimento, esta resposta foi conseqüência de uma redução tanto do teor de gordura como na produção de leite dos animais. O primeiro efeito parece, conforme discutido anteriormente, ser decorrente da formação de ácidos graxos específicos no rúmen, os quais poderiam afetar a lipogênese na glândula mamária (Chilliard et al., 2001).

O efeito sobre a produção de leite, no entanto, parece ser conseqüência da menor ingestão de matéria seca em resposta ao fornecimento do óleo de peixe. Esta resposta pode ser claramente evidenciada na Figura 3. 
Pós-

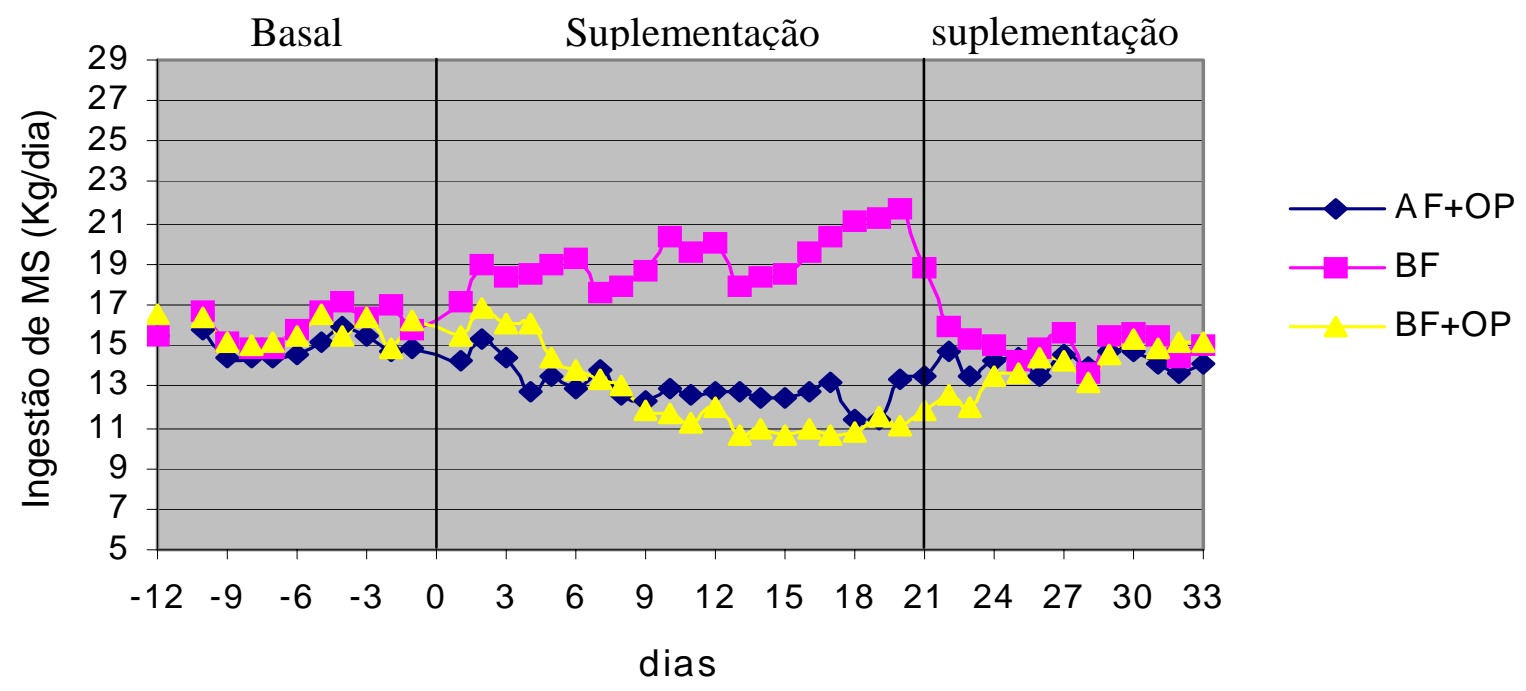

Figura 3 - Consumo de matéria seca (MS) dos animais durante todo o período experimental

A Figura acima mostra que o padrão de consumo de MS pelos animais após o início dos tratamentos foi muito semelhante ao observado para a produção de leite (Figura 2), à exceção de dois aspectos: 1) a redução do consumo nos grupos que receberam OP na dieta ocorreu antes da redução observada na produção de leite em resposta a estes mesmos tratamentos e 2) a magnitude da redução do consumo nos animais tratados com a dieta BF+OP foi maior do que a dos tratados com a dieta AF+OP. Como o consumo dos animais aumentou significativamente $(+4,3 \mathrm{~kg} / \mathrm{dia}, \mathrm{P}=0,02)$ em resposta ao fornecimento da dieta BF (Tabela 7), o consumo de MS deste grupo foi muito superior $(P<0,01)$ ao dos animais que receberam óleo de peixe ao final do período de suplementação (Tabela 6). Os resultados apresentados acima foram semelhantes aos observados quando o consumo foi expresso com porcentagem da MS (Tabelas 6 e 7). Como a redução no consumo dos animais 
que receberam OP ocorreu previamente à redução da produção de leite, é provável que o primeiro fator tenha sido o responsável pela redução no segundo. A redução da digestão da fibra da dieta parece ser a principal causa da depressão no consumo dos animais quando do fornecimento de lipídios insaturados não protegidos na dieta. Alguns mecanismos têm sido propostos para explicar este efeito, sendo os mais importantes: 1) formação de uma "cobertura" de lipídios (filme) sobre as partículas alimentares, impedindo a adesão microbiana (ou da própria enzima fibrolítica) à partícula e 2) efeito citotóxico direto sobre as bactérias fibrolíticas (Jenkins, 1993). Entretanto, estas hipóteses não parecem explicar a maior redução no consumo dos animais que receberam OP associado à dieta com baixa fibra.

A explicação para esta resposta provavelmente reside no fato da maior digestibilidade da MS desta dieta. Isto poderia aumentar o consumo dos animais, como observado no grupo que recebeu a dieta com baixa fibra sem a inclusão de óleo (dieta BF). Entretanto, é provável que a maior concentração de energia na dieta BF+OP (1,90 Mcal de $E L_{\llcorner} / \mathrm{kg}$ MS, Tabela 1$)$ e a depressão da gordura do leite resultantes da inclusão do óleo tenham promovido um grande excedente de energia ingerida, resultando em uma ampla redução no consumo dos animais. Em outras palavras, o consumo dos animais que receberam a dieta $\mathrm{BF}+\mathrm{OP}$ parece ter sido reduzido em resposta à sinais metabólicos de saciedade (NRC, 1989). Entretanto, parece pouco provável que este efeito somado à redução na digestibilidade da fibra pela ação do óleo expliquem, por si só, a perda de cerca de $22 \mathrm{~kg}$ de peso vivo $(\mathrm{P}=0,003)$ observada nestes animais após o início do fornecimento desta dieta (Tabela 7). Supostamente, esta redução de peso pode ser explicada também por um menor enchimento ruminal, de forma que os animais restabeleceram seus pesos iniciais após o retorno à dieta basal (Figura 4). 


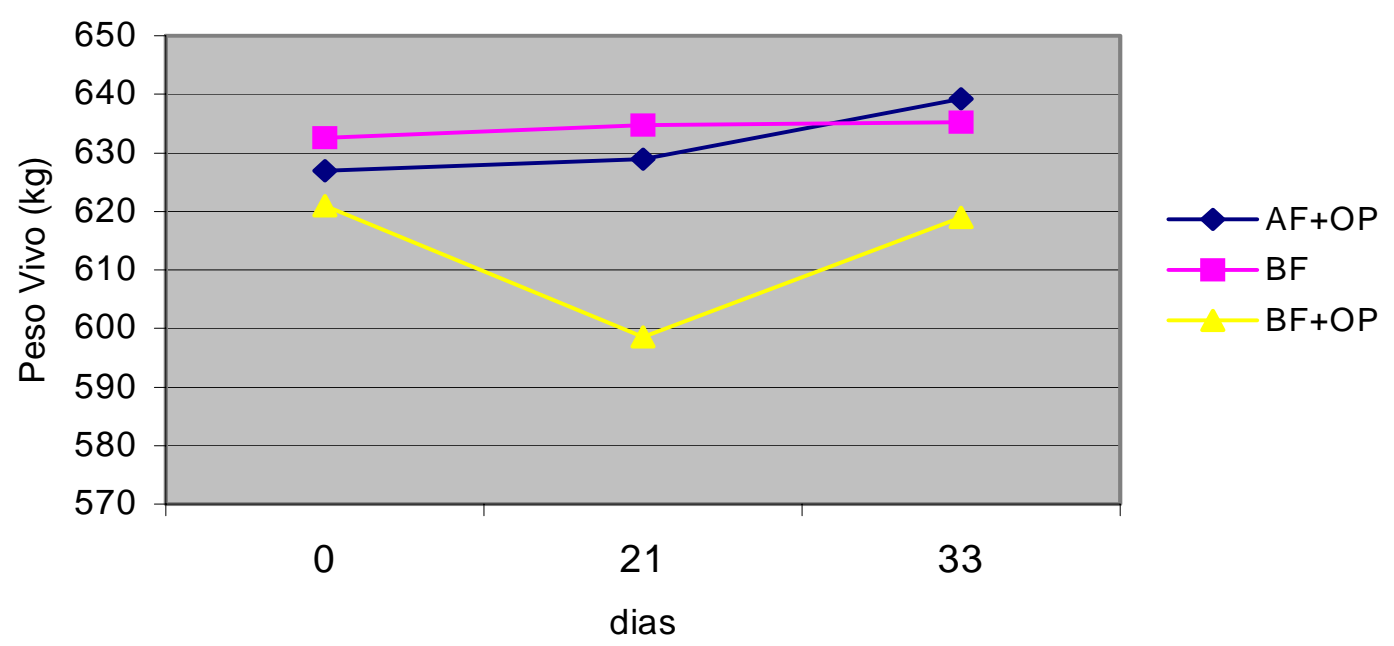

Figura 4 - Variação do peso vivo dos animais após o início dos tratamentos

Tabela 6. Médias corrigidas para peso vivo (PV) e consumo de matéria seca (MS) dos animais em resposta aos tratamentos AF+OP (1), BF (2) e $\mathrm{BF}+\mathrm{OP}(3)$.

\begin{tabular}{lccccccc}
\hline Variáveis & \multicolumn{3}{c}{ Tratamentos } & EPM & \multicolumn{3}{c}{ Contrastes $^{\text {a }}$} \\
& AF+OP & BF & BF+OP & & $1 \times 2$ & $1 \times 3$ & $2 \times 3$ \\
\hline Consumo de MS, kg/d & 13,3 & 19,8 & 11,4 & 1,41 & $* *$ & NS & $* \star$ \\
Peso Vivo, kg & 628,8 & 629,1 & 604,3 & 14,2 & NS & $\dagger$ & $\dagger$ \\
Consumo de MS, \% PV & 2,11 & 3,16 & 1,88 & 0,21 & $\star \star$ & NS & $* \star$
\end{tabular}

EPM = Erro padrão da média; $\mathrm{AF}$ = Alta Fibra; $\mathrm{BF}$ = Baixa Fibra; $\mathrm{OP}$ = Óleo de peixe a Probabilidades das diferenças entre os tratamentos

NS = Não significativo $(P>0,1)$.

$\dagger \mathrm{P}<0,1$

** $P<0,01$ 
Tabela 7. Diferenças entre o peso vivo e o consumo de matéria seca (MS) dos animais durante o período de suplementação (S) em relação aos valores observados previamente durante o período basal (B).

\begin{tabular}{ccccccc}
\hline Variável & Tratamento & \multicolumn{3}{c}{ Período } & \multicolumn{3}{c}{ EPM } & P \\
& & B & S & Dif. (S-B) & & \\
\hline \multirow{2}{*}{ Consumo de MS, kg/d } & AF+OP & 15,1 & 12,6 & $-2,5$ & 0,67 & $*$ \\
& BF & 16,2 & 20,5 & $+4,3$ & 0,84 & $*$ \\
& BF+OP & 15,7 & 11,5 & $-4,2$ & 1,03 & $*$ \\
& AF+OP & 627,0 & 629,0 & $+2,0$ & 8,76 & NS \\
Peso Vivo, kg & BF & 632,5 & 634,8 & $+2,25$ & 9,94 & NS \\
& BF+OP & 621,0 & 598,5 & $-22,5$ & 2,36 & $*$ \\
Consumo de MS, \%PV & AF+OP & 2,43 & 2,01 & $-0,41$ & 0,11 & $*$ \\
& BF & 2,57 & 3,22 & $+0,65$ & 0,10 & $* *$ \\
& BF+OP & 2,54 & 1,91 & $-0,63$ & 0,19 & $*$ \\
\hline
\end{tabular}

$\mathrm{AF}=$ Alta Fibra; $\mathrm{BF}=$ Baixa Fibra; OP = Óleo de Peixe

EPM = Erro padrão da média das diferenças (S-B).

DIF $(\mathrm{S}-\mathrm{B})=$ DIF $(\mathrm{S}-\mathrm{B})=$ Diferenças entre as médias obtidas na $3^{\underline{a}}$ semana do período de suplementação e as obtidas no período basal (B).

NS = Não significativo $(P>0,1)$.

* $P<0,05$

** $\mathrm{P}<0,01$

Embora a concentração de gordura no leite seja mais sensível à manipulação da dieta (Sutton, 1989), efeitos sobre os outros componentes do leite foram também observados neste experimento.

Curiosamente, a concentração de lactose no leite aumentou $(P<0,05)$ após o fornecimento das dietas contendo óleo de peixe (Tabela 5). Além disso, os dados apresentados nesta tabela mostram também que a transição de uma dieta de alta fibra (dieta basal) para uma dieta de baixa fibra sem óleo tendeu $(P=0,08)$ a aumentar a concentração deste componente do leite. Estes dados indicam que tanto o aumento da densidade energética da dieta promovido pela redução do seu teor de fibra, quanto a ingestão do óleo de peixe, resultaram em 
aumento do teor de lactose do leite. Isto talvez explique o maior aumento numérico do teor de lactose observado quando ambas as condições estavam presentes (Tabela 5). O aumento da produção ruminal de ácido propiônico proporcionado pela maior ingestão de grãos (Bauman et al., 1971) talvez explique a resposta observada, uma vez que este composto pode ser convertido à glicose, no fígado, que é a molécula precursora da lactose. Embora a ingestão de óleo de peixe possa reduzir a relação acetato:propionato (Keady \& Mayne, 1999) no rúmen, é provável que esta resposta seja, principalmente, uma conseqüência da redução da produção de acetato, uma vez que a digestão da fibra é reduzida pelo óleo (Jenkins, 1993). O efeito do óleo sobre o teor de lactose talvez possa ser explicado pelo efeito inibitório direto dos ácidos graxos formados no rúmen sobre a síntese de lipídios na glândula mamária. Se o inibidor formado nesta situação pode reduzir também a síntese de novo de lipídios tal como o CLA trans-10 cis-12 (Baumgard et al., 2000), é possível que o acetato, não sendo utilizado para síntese de ácidos graxos, seja oxidado para produção de energia. Isto talvez "poupasse" o uso de glicose para este fim, aumentando sua disponibilidade para a síntese de lactose.

Em geral, a inclusão de lipídios na dieta tem reduzido o teor de proteína do leite (Sutton, 1989, Murphy \& O'Mara, 1993). Entretanto, o fornecimento de óleo de peixe, independentemente do teor de fibra da dieta, não afetou a concentração deste componente do leite no presente experimento (Tabela 5). Este resultado foi semelhante ao obtido por Whitlock et al. (2002), onde $2 \%$ de OP foi incluído na dieta de vacas em lactação. Por outro lado, a concentração de proteína no leite aumentou $(P=0,04)$ após o fornecimento da dieta BF (Tabela 5), de forma que os animais deste tratamento tenderam $(P<0,1)$ a apresentar maior teor de proteína no leite do que os animais que receberam as dietas contendo OP (Tabela 4). A variação temporal deste componente do leite em resposta aos tratamentos pode ser observada na Figura 5. 


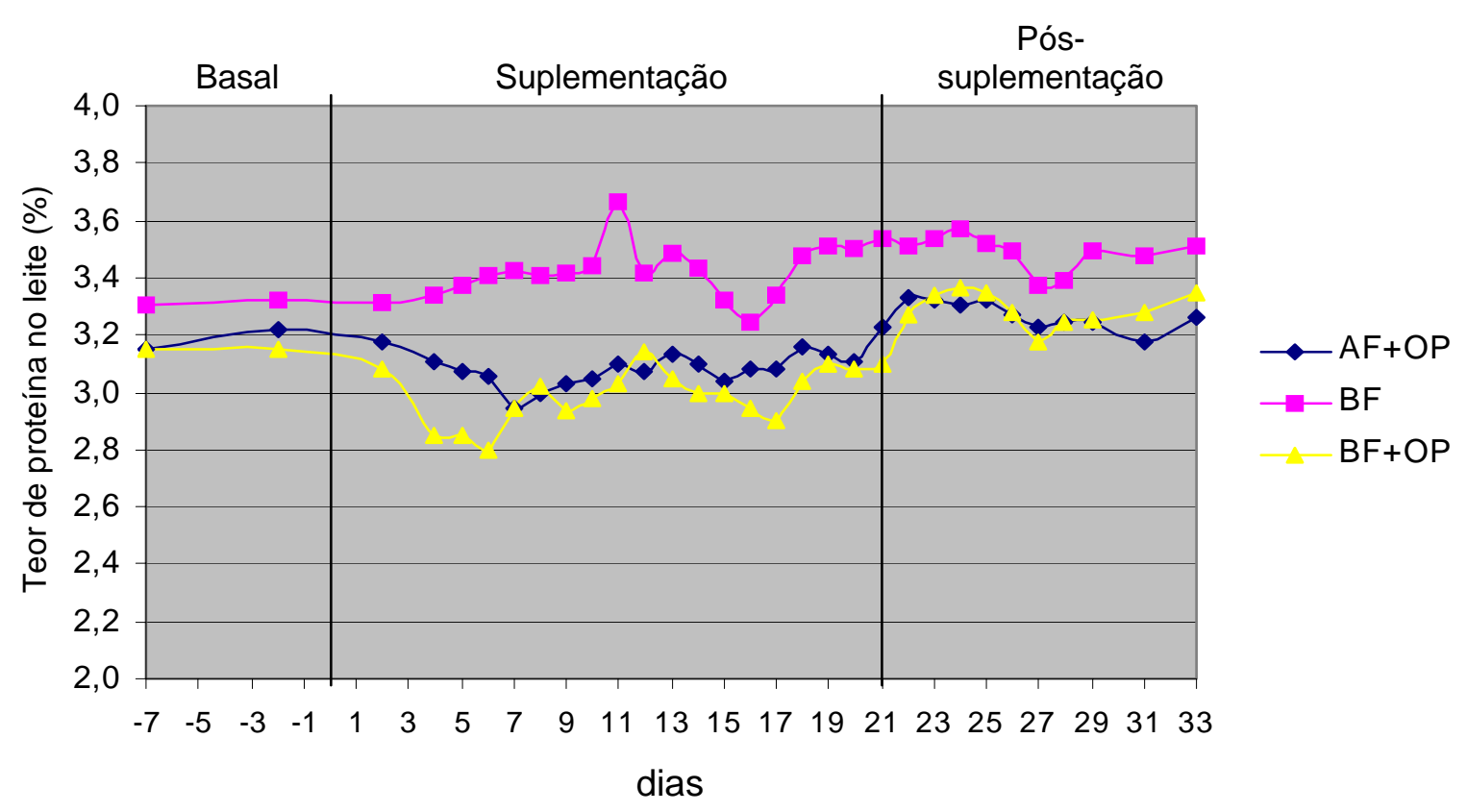

Figura 5 - Teor de proteína no leite dos animais durante todo o período experimental

A redução do teor de proteína do leite observada nos primeiros dias do tratamento $\mathrm{BF}+\mathrm{OP}$ parece ser um efeito de diluição em virtude do aumento da produção de leite destes animais neste mesmo período (Figura 2). Entretanto, um efeito contrário foi observado no grupo $\mathrm{BF}$, onde a produção de leite foi também aumentada neste mesmo período. Isto sugere que o aumento da concentração de energia da dieta pela substituição de carboidratos fibrosos por carboidratos não fibrosos (transição da dieta AF para BF) pode estimular a síntese de proteína na glândula mamária. Isto pode ser conseqüência do aumento de precursores para a síntese de proteína do leite (maior síntese de proteína microbiana) ou do aumento na produção de ácido propiônico no rúmen. Conforme já discutido anteriormente, o ácido propiônico é precursor da glicose, e um aumento da glicemia pode resultar em maior liberação de insulina no sangue. Estudo conduzido por Mackle et al. (1998) mostrou que a infusão de insulina aumentou significativamente o teor e a secreção de proteína do leite 
de vacas em lactação recebendo dietas com níveis adequados de energia e proteína. Embora a concentração arterial de aminoácidos essenciais tenha sido reduzido nos animais que receberam insulina, a maior eficiência de extração destes aminoácidos pela glândula mamária aliado a um maior fluxo sangüíneo para este tecido permitiram uma maior secreção de proteína no leite. Estes resultados indicam que a insulina pode, direta ou indiretamente, afetar a síntese de proteína do leite. No presente experimento, a diferença entre as dietas $\mathrm{BF}+\mathrm{OP}$ e BF é basicamente devida à substituição de parte do milho pelo óleo de peixe (Tabela 1), o que provavelmente reduziu a produção de ácido propiônico e de proteína microbiana no rúmen. Isto explicaria, pelo menos em parte, porque somente no grupo BF foi observado aumento no teor e na secreção de proteína do leite (Tabela 5). 


\subsubsection{Perfil de ácidos graxos do leite}

Para estudar as alterações temporais no perfil de ácidos graxos do leite, amostras de leite foram coletadas ao longo de todo o período experimental, conforme descrito no item Material e Métodos. Entretanto, devido ao alto custo das análises, nem todas as amostras coletadas foram submetidas à determinação do perfil de ácidos graxos. A escolha das amostras a serem analisadas foi baseada na variação do teor de gordura do leite ao longo do experimento, conforme ilustra a figura abaixo (Fig. 6).

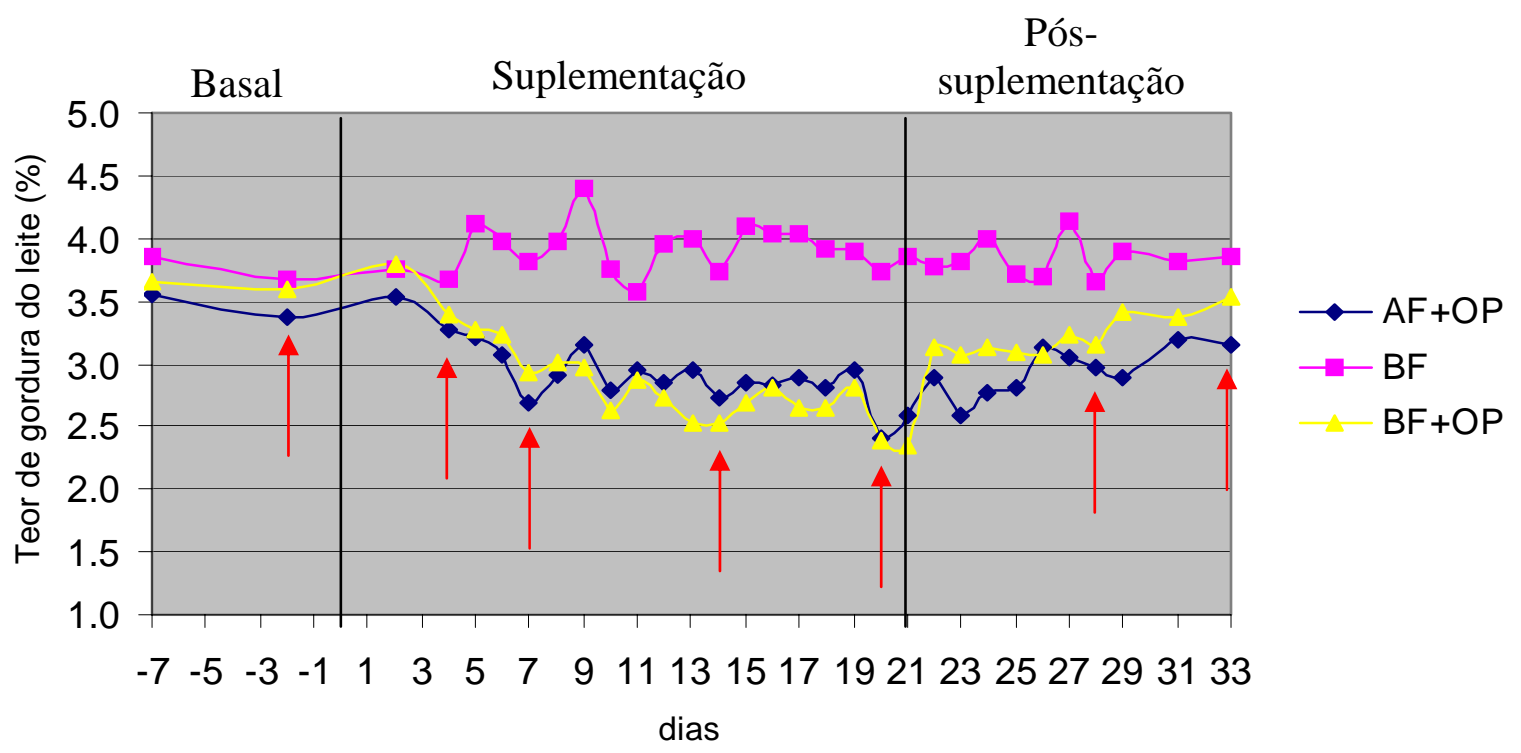

Figura 6 - Momentos de coleta das amostras de leite destinadas à análise do perfil de ácidos graxos (indicados pelas setas vermelhas)

Para avaliação dos efeitos de tratamento sobre o perfil e secreção ( $g / d i a)$ dos ácidos graxos do leite, somente as amostras coletadas no último dia do período experimental (dia 20) foram utilizadas nas análises. Da mesma forma que para as outras variáveis, os valores observados durante o período basal (dia -2) foram usados como covariáveis no modelo. Esta análise, 
obviamente, não nos permitiu estudar as variações no tempo, mas serviu como base para selecionarmos os possíveis ácidos graxos relacionados à DGL e prováveis mecanismos envolvidos em tal resposta.

Os resultados destas análises podem ser vistos nas Tabelas 9, 10 e 11.

Tabela 9. Perfil de ácidos graxos do leite dos animais em resposta aos tratamentos AF+OP (1), BF (2) e BF+OP (3)

\begin{tabular}{|c|c|c|c|c|c|c|c|}
\hline \multirow[t]{2}{*}{ Ácido graxo } & \multicolumn{3}{|c|}{ Tratamentos } & \multirow[t]{2}{*}{ EPM } & \multicolumn{3}{|c|}{ Contrastes $^{a}$} \\
\hline & $\mathrm{AF}+\mathrm{OP}$ & $\mathrm{BF}$ & $\mathrm{BF}+\mathrm{OP}$ & & $1 \times 2$ & $1 \times 3$ & $2 \times 3$ \\
\hline cadeia curta (C4-C10) & 9,15 & 9,60 & 8,60 & 0,34 & NS & NS & NS \\
\hline cadeia média (C12-C16) & 56,0 & 48,8 & 48,8 & 1,30 & $\star *$ & ** & NS \\
\hline Cadeia longa (>18C) & 33,5 & 40,5 & 40,1 & 1,21 & ** & ** & NS \\
\hline C18:1cis & 10,9 & 23,6 & 12,9 & 1,72 & ** & $\dagger$ & ** \\
\hline C18:1trans & 15,3 & 4,41 & 18,8 & 1,90 & ** & * & ** \\
\hline Relação C18:1trans/cis & 1,38 & 0,19 & 1,50 & 0,18 & ** & NS & ** \\
\hline C18:2 total $^{1}$ & 1,88 & 3,30 & 2,47 & 0,20 & $\star \star$ & * & $\star *$ \\
\hline$>20 C^{2}$ & 0,27 & 0,27 & 0,28 & 0,01 & NS & NS & NS \\
\hline CLA total $\left.\right|^{3}$ & 2,85 & 0,61 & 3,24 & 0,39 & ** & NS & $\star \star$ \\
\hline Cadeia ímpar ${ }^{4}$ & 4,28 & 3,58 & 4,05 & 0,11 & $* \star$ & NS & $\dagger$ \\
\hline Índice desaturase ${ }^{5}$ & 0,24 & 0,49 & 0,32 & 0,03 & ** & * & $\star \star \star$ \\
\hline
\end{tabular}

EPM = Erro padrão da média; $\mathrm{AF}=$ Alta Fibra; $\mathrm{BF}$ = Baixa Fibra; $\mathrm{OP}=$ Óleo de peixe ${ }^{a}$ Probabilidades das diferenças entre os tratamentos

NS = Não significativo $(P>0,1)$

$\dagger \mathrm{P}<0,1$ * $P<0,05$ ** $P<0,01$

${ }^{1}(\mathrm{C} 18: 2 \mathrm{c} 9 \mathrm{c} 12+\mathrm{C} 18: 2 \mathrm{t}$ t9c12)

${ }^{2}(\mathrm{C} 20: 0+\mathrm{C} 20: 1)$

${ }^{3}(\mathrm{c} 9 \mathrm{t} 11+\mathrm{t} 9 \mathrm{c} 11+\mathrm{t} 10 \mathrm{c} 12)$

${ }^{4}(\mathrm{C} 11+\mathrm{C} 13+\mathrm{C} 15+\mathrm{C} 17)$

$\left.{ }^{5} \mathrm{C} 12: 1 \mathrm{c} 9+\mathrm{C} 14: 1 \mathrm{c} 9+\mathrm{C} 16: 1 \mathrm{c} 9+\mathrm{C} 18: 1 \mathrm{c} 9+\mathrm{CLAC} 9 \mathrm{t} 11\right) /(\mathrm{C} 12+\mathrm{C} 14+\mathrm{C} 16+\mathrm{C} 18+\mathrm{C} 18: 1 \mathrm{t} 11)$

Os resultados acima mostram que o fornecimento de OP, independentemente do teor de fibra da dieta, não afetou a concentração de ácidos graxos de cadeia curta no leite em comparação com a dieta BF. Quando 
cada tratamento foi comparado com os valores obtidos durante o período basal, uma redução de 2 unidades percentuais $(P=0,02)$ na concentração dos ácidos graxos de cadeia curta foi observada em resposta à dieta $B F+O P(10,9 \%$ vs. 8,9\% para dieta basal e BF+OP, respectivamente). A magnitude desta redução correspondeu à soma das reduções observadas em resposta aos tratamentos $A F+O P$ e $B F(-1,1$ e $-0,9 \%$, respectivamente). Estes dados sugerem que os efeitos do OP e da redução do nível de fibra podem ser aditivos na redução da concentração de ácidos graxos de cadeia curta. Este efeito foi claramente evidenciado quando as respostas aos tratamentos foram avaliadas para os ácidos graxos individualmente (dados não apresentados), onde, à exceção de $\mathrm{C} 4$, a concentração de todos os outros ( $\mathrm{C} 6$ a $\mathrm{C} 10)$ foram menores $(\mathrm{P}<0,05)$ na dieta $\mathrm{BF}+\mathrm{OP}$ em relação aos demais tratamentos, embora a análise conjunta não tenha detectado esta diferença (Tabela 9). Por outro lado, a secreção dos ácidos graxos de cadeia curta $(\mathrm{g} / \mathrm{dia})$ foi menor $(\mathrm{P}<0,01)$ nos animais que receberam OP, independentemente da dieta (Tabela 10).

Tabela 10. Secreção dos ácidos graxos do leite (g/dia) em resposta aos tratamentos $\mathrm{AF}+\mathrm{OP}(1), \mathrm{BF}(2)$ e $\mathrm{BF}+\mathrm{OP}(3)$

\begin{tabular}{lcccccccc}
\hline Ácido graxo & \multicolumn{3}{c}{ Tratamentos } & EPM & \multicolumn{3}{c}{ Contrastes $^{\text {a }}$} \\
& AF+OP & BF & BF+OP & & $1 \times 2$ & $1 \times 3$ & $2 \times 3$ \\
\hline cadeia curta (C4-C10) & 41,6 & 71,2 & 36,5 & 6,59 & $* *$ & NS & $\star \star$ \\
cadeia média (C12-C16) & 256,4 & 356,9 & 213,4 & 32,9 & $\star *$ & $\dagger$ & $* *$ \\
Cadeia longa (>18C) & 144,8 & 294,0 & 180,3 & 23,56 & $* *$ & $\dagger$ & $* *$
\end{tabular}

EPM = Erro padrão da média; AF = Alta Fibra; BF = Baixa Fibra; OP = Óleo de peixe

a Probabilidades das diferenças entre os tratamentos

NS = Não significativo $(P>0,1)$

$\dagger \mathrm{P}<0,1$

* $P<0,05$

** $P<0,01$ 
Os resultados observados acima são conseqüência da redução, em relação ao período basal, da secreção destes ácidos graxos nos grupos $\mathrm{AF}+\mathrm{OP}$ e BF+OP (-26,7 e -33,2 g/dia, respectivamente), enquanto que a transição para a dieta BF não afetou esta variável. De uma forma geral, os dados acima demostram que o fornecimento de dietas contendo OP promove grande inibição da secreção de ácidos graxos de cadeia curta, e que a magnitude desta resposta parece ser maximizada quando dietas de baixa fibra são oferecidas.

Os efeitos sobre os ácidos graxos de cadeia média são de grande interesse, visto que os saturados pertencentes a este grupo (e.g. láurico, mirístico e palmítico) são potencialmente hipercolesterolêmicos (Williams,2000).

Analisando a Tabela 9, nota-se que a concentração destes ácidos graxos foram inferiores $(P<0,01)$ nos animais que receberam dietas com baixo teor de fibra, independentemente da inclusão de OP. A magnitude desta redução foi proporcional ao aumento da concentração dos ácidos graxos de cadeia longa no mesmos tratamentos (cerca de 7 unidades percentuais). A menor concentração de ácidos graxos de cadeia média nos grupos BF e BF+OP em relação ao grupo AF+OP (Tabela 9) foi uma conseqüência da redução $(P<0,05)$ observada neste mesmos grupos após a transição da dieta basal para as respectivas dietas (55,5 vs. 49,5 e 55,4 vs. 49,4). Esta mesma magnitude de resposta foi observada, mas em sentido contrário, para os ácidos graxos de cadeia longa, o que refletiu nos valores apresentados na tabela acima. Esta resposta pode ser uma conseqüência da alteração do padrão de fermentação ruminal quando do fornecimento de dietas com alto teor de concentrados.

Presumidamente, a maior produção de ácido propiônico neste tipo de dieta (Bauman et al., 1971) resultaria em maior concentração de glicose no sangue e, portanto, maior secreção de insulina. Como a insulina estimula a lipogênese no tecido adiposo (Bauman, 2000), poderia haver uma redução no aporte de acetato para a glândula mamária e, por conseqüência, menor síntese "de novo" de ácidos graxos. Isto poderia levar a uma menor concentração de ácidos graxos de cadeias curta e média no leite e, por conseqüência, aumento dos de 
cadeia longa. Por outro lado, uma redução da concentração de ácidos graxos de cadeia longa também poderia ocorrer, visto que a insulina reduz a lipólise. Entretanto, como este efeito é mais pronunciado quando as vacas se encontram em início de lactação (Bauman e Griinari, 2003), tal resposta não seria esperada no presente experimento. Cabe aqui destacar que o efeito da insulina sobre o aporte de acetato para a glândula mamária não parece, de fato, ser a causa da DGL, conforme proposto por McGuire et al. (1995). Esta afirmação é consistente com o fato de, no presente experimento, a redução do teor de fibra da dieta, isoladamente, não resultou em DGL.

Por outro lado, quando se avaliou o efeito das dietas sobre a secreção diária dos ácidos graxos no leite (Tabela 10), pôde-se notar que, assim como para os de cadeia curta, a redução da concentração de ácidos graxos de cadeias média e longa foram grandemente reduzidos nos animais que receberam OP. Além disso, houve ainda uma tendência $(P=0,09)$ de maior redução dos ácidos graxos de cadeia longa, e menor redução dos de cadeia média, quando o OP foi incluído na dieta de baixa fibra do que na dieta de alta fibra. Interessantemente, quando os efeitos de tratamento foram avaliados cem relação ao período basal, observou-se que a transição da dieta de alta fibra para baixa fibra, sem a inclusão do OP, tendeu $(P=0,09)$ a aumentar a secreção de ácidos graxos de cadeia longa em cerca de $72 \mathrm{~g} / \mathrm{dia}$, mas não afetou a secreção dos de cadeias curta e média. Como a transição da dieta basal para BF aumentou $(P<0,05)$ o consumo de MS em 4,3 kg/dia (Tabela 07), esperar-se-ia que tanto o aporte de AGV produzidos no rúmen, como o dos ácidos graxos de cadeia longa oriundos da dieta, fossem aumentados para a glândula mamária. Obviamente, isto poderia resultar em maior secreção dos ácidos graxos sintetizados "de novo" e dos de cadeia longa, oriundos da dieta. Entretanto, conforme mencionado, somente a secreção dos de cadeia longa aumentou na transição da dieta basal para a dieta BF. Portanto, duas hipóteses parecem prováveis: 1) A maior produção de propionato na dieta BF aumentou as concentrações de glicose e insulina, e esta última estimulou a lipogênese no 
tecido adiposo de forma que, apesar do maior aporte de acetato (maior ingestão de MS), a quantidade deste AGV que efetivamente alcançou a glândula mamária permaneceu praticamente a mesma e 2) Por alguma razão, o maior aporte de energia na dieta de baixa fibra estimulou a atividade da enzima lipoproteína lipase, responsável pela captação de ácidos graxos oriundos da dieta, os quais são transportados sob a forma de lipoproteínas. Independentemente do mecanismo operante, o aumento da concentração de grãos na dieta alterou positivamente a relação entre os ácidos graxos de cadeias média e longa no leite (Tabela 9).

Diferentemente do efeito observado para a dieta de BF isoladamente, a redução da concentração dos ácidos graxos de cadeia média em resposta ao tratamento $\mathrm{BF}+\mathrm{OP}$ foi uma conseqüência da maior magnitude de redução da secreção destes ácidos graxos no leite, em comparação com a redução observada na secreção dos ácidos graxos de cadeia longa (-153g/dia vs. $42,8 \mathrm{~g} /$ dia, respectivamente). Para a dieta $A F+O P$, as diferenças de secreção foram menores, porque a secreção dos ácidos graxos de cadeia média foi menos inibida e os de cadeia longa foi mais inibida (-111,6 vs. $-79,9 \mathrm{~g} / \mathrm{dia}$, respectivamente). $O$ reflexo destas inibições em relação à dieta basal podem ser vistos na Tabela 10. Como conseqüência destas diferenças no grau de inibição da secreção dos ácidos graxos sintetizados "de novo" daqueles oriundos da circulação, em função do nível de fibra da dieta suplementada com OP, a proporção entre estes grupos de ácidos graxos diferiu entre os tratamentos AF+OP e BF+OP (Tabela 9).

Em suma, a inclusão de OP às dietas resultou em grande inibição da secreção de todos os ácidos graxos do leite, o que é consistente com a ampla redução da secreção de gordura observada (Tabelas 4 e 5). Em média, a redução na secreção dos ácidos graxos de cadeia média, em termos absolutos (g/dia), foi de maior magnitude, seguido pelos de cadeia longa e, por fim, os de cadeia curta. Entretanto, em termos relativos (\%), as reduções formam maiores para os de cadeia curta, seguidos pelos de média e, finalmente, longa. 
Entretanto, o nível de fibra da dieta afetou tais respostas ao OP, de forma que a redução da secreção dos ácidos graxos de cadeia longa foi menor, e os de cadeia média maior, na dieta com baixa fibra.

A razão da ampla redução na secreção de todos os ácidos graxos quando do fornecimento de dietas contendo OP é ainda desconhecida, mas os resultados do presente experimento sugerem que tanto as enzimas responsáveis pela síntese "de novo" (ACC e FAS) de ácidos graxos, quanto a responsável pela captação de ácidos graxos pré-formados (lipoproteína lipase$\mathrm{LPL}$ ), podem estar sendo inibidas. Esta última hipótese é forçada pelos resultados obtidos por Ahnadi et al. (1998), os quais mostraram uma redução da abundância de RNAm da LPL na glândula mamária de vacas recebendo OP.

Alternativamente, a inibição pode se dar na enzima responsável pela esterificação dos ácidos graxos (glicerol-P acil transferase), uma vez que a secreção de todos os ácidos graxos foi inibida pelo OP. Uma outra possibilidade seria a inibição da enzima $\Delta-9$ dessaturase, fundamental para a manutenção da fluidez da gordura do leite (Chilliard et al., 2000). A atividade desta enzima não foi avaliada no presente experimento, mas a relação entre seus produtos e substratos podem fornecer uma medida indireta de sua atividade (Tabela 9). Como se pode notar, esta relação foi menor $(P<0,01)$ nos tratamentos contendo $\mathrm{OP}$, particularmente quando em associação à dieta com alta fibra $(\mathrm{P}<0,05)$. Isto mostra que o fornecimento de OP resultou em menor quantidade de produtos da enzima por unidade de substratos disponível, indicando que a enzima encontrase inibida. Corroborando este resultado, Ahnadi et al. (1998) observaram uma redução na quantidade de RNAm da enzima $\Delta-9$ dessaturase na glândula mamária de vacas que receberam OP. Embora o CLA trans-10 cis-12 seja um potente inibidor desta enzima e de inúmeras outras envolvidas na síntese de lipídios (Baumgard et al., 2002), altas doses deste CLA precisam ser fornecidas para inibir a delta-9 dessaturase (Baumgard et al., 2001). Portanto, embora a concentração de CLA trans-10 cis-12 no leite tenha aumentado em resposta ao OP no presente estudo (Tabela 11), este aumento foi muito inferior ao observado 
em trabalhos onde esta enzima foi inibida $(>0,32 \mathrm{~g} / 100 \mathrm{~g})$, de forma que outros inibidores podem estar envolvidos. Consistente com esta hipótese, Enjalbert et al. (1998) observaram uma relação negativa entre a captação de C18:1trans pela glândula mamária e a dessaturação de C18:0 a C18:1c9.

Ao contrário do que geralmente ocorre com o CLA trans-10 cis-12, grandes aumentos na concentração de isômeros C18:1trans no leite têm sido observados em diversos estudos onde OP foi incluído na dieta dos animais (Chilliard et al., 2001).

De maneira similar, o fornecimento de OP no presente experimento aumentou $(P<0,01)$ a concentração de total de C18:1trans, mas reduziu $(P<0,01)$ a concentração de C18:1cis no leite dos animais. Como resultado, a relação C18:1 trans/C18:1cis foi muito maior $(P<0,01)$ no leite dos animais que receberam OP. Além disso, a concentração de C18:1trans foi maior $(P=0,02)$ quando o OP foi adicionado à dieta de baixa fibra do que na dieta de alta fibra. Esta mesma resposta tendeu $(P=0,08)$ a ocorrer para os $C 18: 1$ cis.

A redução na concentração de C18:1cis e aumento de C18:1trans foi também evidente quando os tratamentos foram comparados com os valores observados durante o período basal. Neste caso, o fornecimento de OP resultou em reduções médias de 10 e 8\% na concentração de C18:1cis no leite $(P<0,01)$, nas dietas com alto e baixo teor de fibra, respectivamente. Em contrapartida, a concentração de C18:1trans aumentou em 12,7 e 15,6\% nas dietas AF+OP e $\mathrm{BF}+\mathrm{OP}$, respectivamente. $\mathrm{O}$ transição da dieta basal para de baixa fibra (BF) também afetou $(P<0,05)$ a concentração de $C 18$ :1cis e C18:1trans no leite, mas a magnitude destas respostas foi muito inferior à observada nas dietas onde foi adicionado OP. Quando os ácidos graxos foram avaliados individualmente (Tabela 11), observou-se que a concentração de muitos C18:1trans foram maiores $(P<0,05)$ nos animais que receberam OP. Por outro lado, a ampla redução da concentração do total de C18:1cis em resposta ao OP (Tabela 9) deveu-se, principalmente, à queda significativa $(\mathrm{P}<0,0001)$ no teor de $\mathrm{C} 18$ :1cis9. Entretanto, a concentração de alguns isômeros cis, especialmente o C18:1cis- 
11 , aumentou significativamente $(P<0,01)$ no leite dos animais que receberam OP. Esta resposta também foi observada por outros autores (Franklin et al., 1999, Offer et al., 1999, Donovan et al., 2000, Whitlock et al., 2002).

Dos isômeros C18:1trans, o aumento mais expressivo foi o do C18:1trans11 (ácido vaccênico), o qual correspondeu a mais de 60\% do total (Tabela 11). Os restantes foram representados principalmente pelos isômeros trans-10, trans9 e trans- 12.

O aumento da concentração de ácido vaccênico resultou em um aumento proporcional da concentração do CLA cis-9 trans-11 no leite dos animais que receberam OP (Figura 7). Esta resposta reforça o conceito de que grande parte do CLA cis-9 trans-11 presente no leite é sintetizado endogenamente a partir do ácido vaccênico, por ação da enzima delta-9 dessaturase (Griinari et al., 2000). O modelo quadrático da regressão sugere que pode haver um limite a partir do qual aumentos do aporte de ácido vaccênico para a glândula mamária não resulta em incrementos na síntese de CLA cis-9 trans-11. Chilliard et al. (2001) sugeriram que a menor relação entre CLA cis-9 trans-11 e C18:1trans-11 no leite de animais recebendo dietas suplementadas com $\mathrm{OP}$, em relação àqueles recebendo dietas contendo óleos vegetais, poderia ser devido a uma limitação da capacidade da $\Delta-9$ dessaturase em sintetizar o CLA cis-9 trans-11 quando a concentração de C18:1trans-11 alcança valores superiores à 10-12\% do total de ácidos graxos do leite.

Se as especulações acima são de fato verdadeiras, isso poderia fornecer uma explicação adicional para a menor relação entre produtos e substratos da enzima $\Delta-9$ dessaturase observada no presente experimento (Tabela 9), visto que o par CLA c9t11/C18:1t11 foi incluído na relação. 


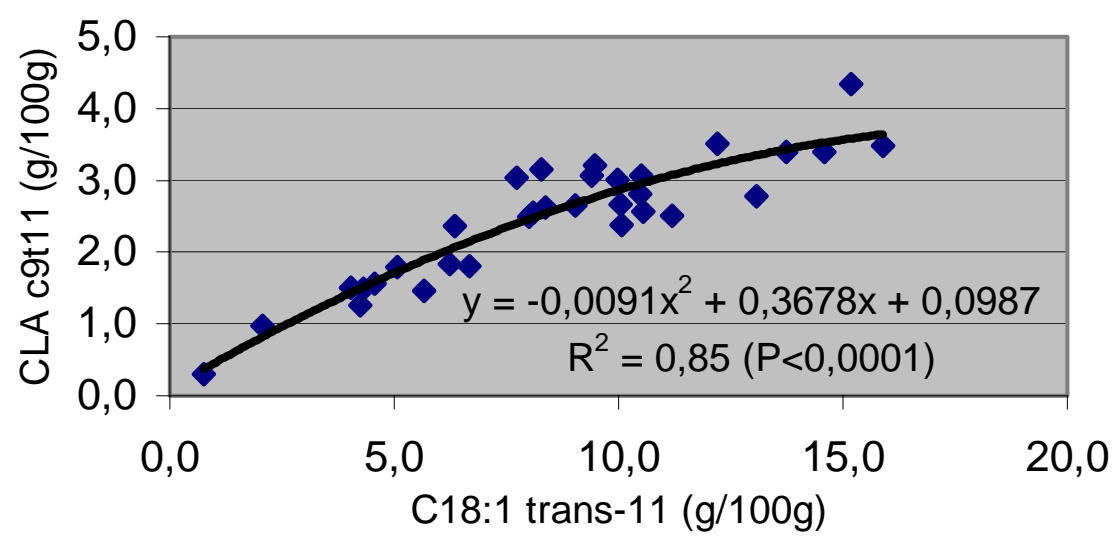

Figura 7 - Relação entre as concentrações de ácidos vaccênico (C18:1trans-11) e de CLA cis-9 trans-11 no leite dos animais que receberam OP

O aumento da concentração de C18:1trans-11 e de outros C18:1trans no leite, quando do fornecimento de OP na dieta (Tabela 11), sugere que duplas ligações do tipo trans são preferencialmente formadas pelas bactérias ruminais em tais condições e, além disso, que a biohidrogenação destas ligações está sendo inibida. Esta última hipótese é consistente com a ampla redução da concentração de C18:0 (ácido esteárico) no leite observada no presente experimento $(P<0,01$, Tabela 11) e em outros onde os animais também receberam OP na dieta (Donovan et al., 2000; Whitlock et al., 2002).

Consistente com estes resultados, Shingfield et al. (2002) observaram, através do uso de marcadores e coleta de amostras no omaso, uma grande redução (283 vs. $47 \mathrm{~g} / \mathrm{dia}$ ) da quantidade de C18:0 que atingiu o omaso de vacas em lactação após o fornecimento de $250 \mathrm{~g} /$ dia de OP. Paralelamente, o fluxo de C18:1trans para o omaso aumentou (38 vs. $182 \mathrm{~g} / \mathrm{dia}$ ) nos mesmo animais.

A redução da formação de ácido esteárico parece, de fato, intimamente relacionada ao acúmulo de C18:1trans no rúmen de vacas que receberam OP. Esta idéia fica claramente evidenciada na curva de regressão abaixo (Figura 8), 
assumindo-se que o perfil de ácidos graxos do leite é, neste caso, um reflexo do que ocorre no rúmen.

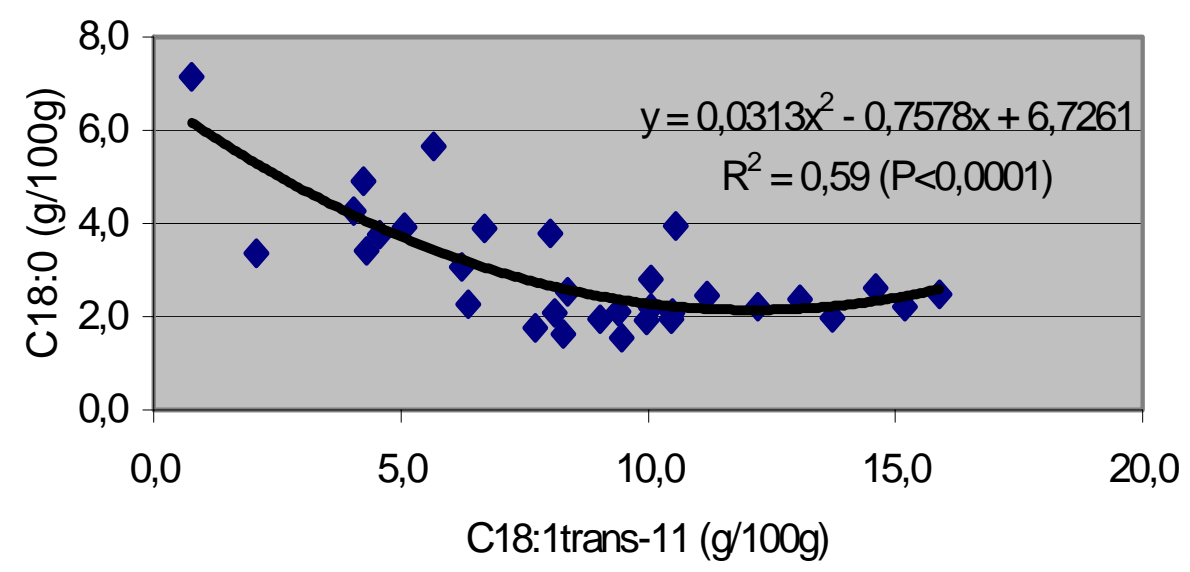

Figura 8 - Regressão entre a concentração de C18:1trans-11 (ácido vaccênico) e a concentração de C18:0 (ácido esteárico) no leite dos animais que receberam as dietas contendo OP.

Este mesmo padrão de resposta foi observado para outros ácidos graxos trans secretados no leite (dados não apresentados). Curiosamente, a concentração de C18:0 no leite dos animais que receberam OP no presente experimento (Tabela 11) foi a menor já observada na literatura revisada. Isto talvez se deva à baixa ingestão de ácidos graxos poliinsaturados presentes na dieta basal do presente experimento, uma vez que milho e farelo de soja foram os únicos ingredientes concentrados utilizados nas dietas. Corroborando esta hipótese, Whitlock et al. (2002) encontraram apenas 3\% de C18:0 na gordura do leite quando os animais receberam dieta semelhante à utilizada no presente experimento, inclusive quanto ao nível de inclusão de OP ( $2 \%$ da MS). Entretanto, quando o OP foi incluído junto com soja extrusada (para aumentar a ingestão de ácido linoléico), a concentração de C18:0 foi aproximadamente o dobro da dieta contendo apenas OP. 
A redução no aporte de C18:0 para a glândula mamária parece justificar, em grande parte, a redução $(P<0,01)$ da concentração de ácido oléico (C18:1 cis-9) no leite dos animais que receberam OP no presente experimento (Tabela 11). Isto porque grande parte ( $>50 \%)$ do ácido oléico presente no leite é oriundo da dessaturação do ácido esteárico na glândula mamária, por ação da enzima $\Delta$ 9 dessaturase (Chilliard et al., 2000). Soma-se a isso o fato desta enzima estar aparentemente inibida nos animais que receberam OP (Tabela 9).

Similarmente ao observado em outros trabalhos (Chilliard et al., 2001; Whitlock et al., 2002; Ärölä et al. ,2002, Abughazaleh et al., 2003), a inclusão de OP à dieta dos animais resultou em redução na secreção de gordura do leite no presente experimento (Tabelas 4 e 5). A concentração do CLA trans-10 cis-12, único ácido graxo reconhecidamente inibidor da síntese de gordura do leite (Baumgard et al., 2000), aumentou $(P<0,05)$ no leite dos animais que receberam OP (Tabela 11). Embora estatisticamente não significativo, este aumento foi mais pronunciado quando o OP foi incluído na dieta de baixa fibra (0,06 vs. $0,04 \mathrm{~g} / 100 \mathrm{~g}$ ), sugerindo que o nível de fibra da dieta pode afetar a resposta ao OP em nível ruminal. O presente experimento é, até o momento, o único estudo a avaliar os efeitos do OP em dietas contendo níveis distintos de fibra. Outros autores (Whitlock et al., 2002; Gulati et al., 2003; Abughazaleh et al., 2003) também observaram aumentos do teor de CLA trans-10 cis-12 no leite em resposta ao fornecimento de OP, embora Gulati et al. (2003) não tivessem observado DGL nos animais. Essa resposta, segundo os próprios autores, talvez seja explicada pelo fato de terem usado OP protegido por encapsulação em uma matriz protéica.

Por outro lado, alguns autores observaram DGL sem qualquer aumento na concentração de CLA trans-10 cis-12 no leite (Chilliard et al., 1999; Griinari et al., 2000). Embora o teor deste CLA tenha aumentado em resposta ao fornecimento de dietas contendo OP no presente experimento, a DGL observada foi maior do que poderia ser predito com base na sua concentração em experimentos onde a DGL foi induzida pelo fornecimento de dietas com baixa 
fibra adicionada de óleos vegetais (Griinari et al., 1999). Estes dados indicam que a DGL observada quando se fornece dietas contendo OP deve envolver outros inibidores.

Embora um efeito inibitório dos ácidos graxos C18:1trans sobre a lipogênese na glândula mamária tem sido sugerido (Wonsil et al., 1994), poucos estudos avaliaram diretamente efeitos específicos devido à dificuldade de se conseguir fontes purificadas dos isômeros (Bauman e Griinari., 2003). Os únicos estudos com isômeros purificados de C18:1trans não observaram efeito da infusão abomasal de C18:1trans-9 (Rindsig e Schultz, 1974) ou de uma mistura de C18:1trans-11 e C18:1trans-12 (Griinari et al., 2000) sobre a síntese de gordura do leite.

Ao contrário do que normalmente se observa para o CLA trans-10 cis-12, a concentração de C18:1trans-10 no leite tem aumentado em vacas alimentadas com dietas contendo OP (Griinari et al. 2000; Arola et al., 2002). No presente experimento, a concentração de $\mathrm{C} 18: 1$ trans-10 no leite tendeu $(\mathrm{P}=0,06)$ a aumentar somente no tratamento BF+OP (Tabela 11), sugerindo novamente que o nível de fibra da dieta pode afetar a resposta ao OP. Como aumentos da concentração de C18:1trans-10 também tem sido observados em situações de clássica DGL (Griinari et at., 1998), parece provável que este ácido graxo possa também estar envolvido diretamente com a DGL. A falta de isômeros purificados de C18:1trans-10 não tem permitido avaliar esta hipótese diretamente (Bauman e Griinari, 2003).

Para estudar a relação entre este e outros ácidos graxos com a DGL, uma análise do comportamento destas variáveis, ao longo do tempo, foi conduzida no presente experimento (Figura 6). Embora o fornecimento de OP tenha afetado a concentração de muitos ácidos graxos do leite (Tabela 11), a variação temporal de alguns deles foram especialmente relacionados às alterações do teor de gordura do leite (Figura 9). 

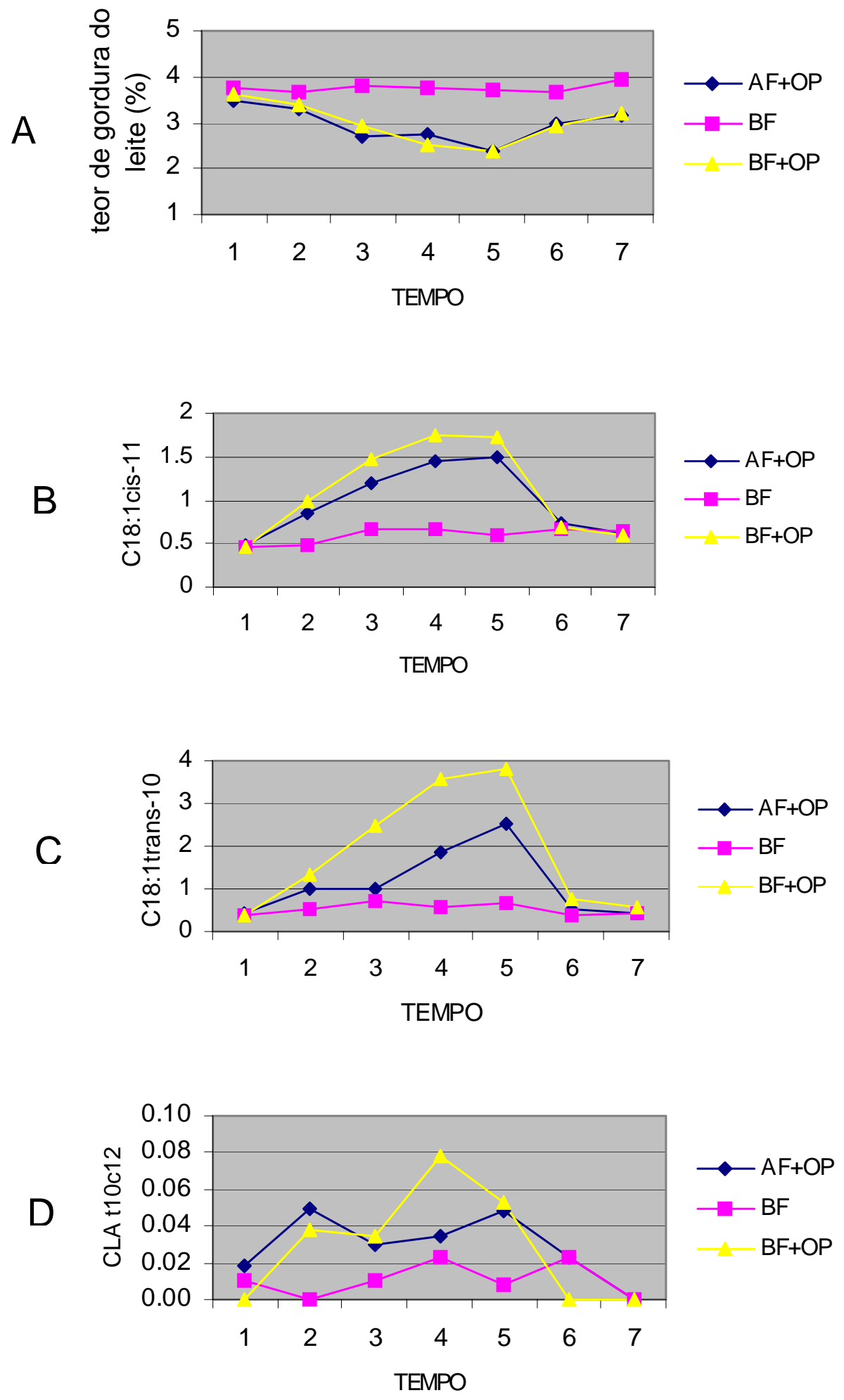


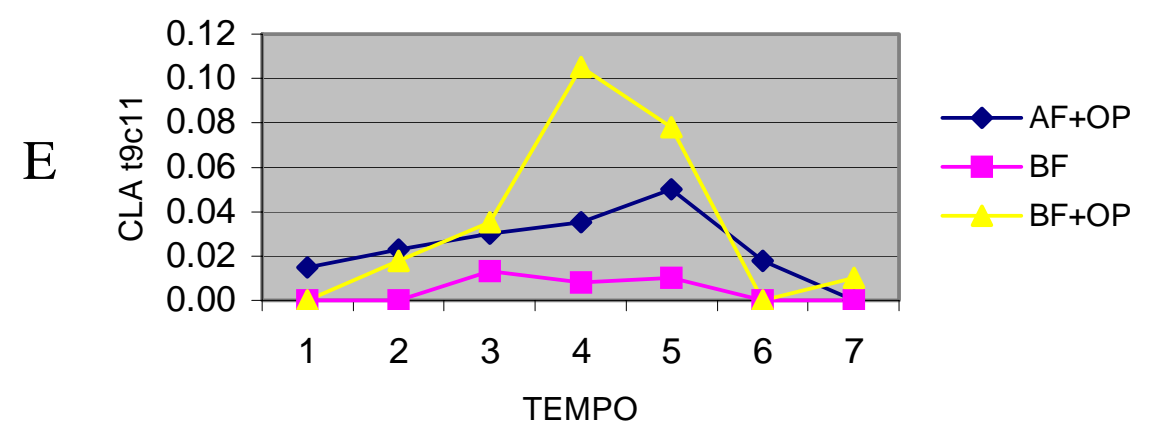

Figura 9 - Variação do teor de gordura do leite $(A)$ e das concentrações ( $g / 100 g)$ de C18:1cis-11 (B), C18:1trans-10 (C), CLA t10c12 (D) e CLA t9c11 (E) na gordura do leite ao longo do experimento (TEMPO = Momentos de coleta das amostras, Fig.6).

Uma análise da figura acima mostra que o aumento da concentração de C18:1cis-11 ao longo do tempo foi estreitamente relacionado à queda no teor de gordura do leite do animais, em ambos os tratamentos, durante o período de suplementação (TEMPOS 2 a 5). Após o retorno à dieta basal (TEMPOS 6 E 7), a elevação do teor de gordura do leite foi acompanhada pela redução da concentração de C18:1cis-11. Em outras palavras, a variação em C18:1cis-11 ao longo do experimento foi praticamente o espelho da variação do teor de gordura do leite. Embora a concentração dos outros ácidos graxos também tenham aumentado durante a queda do teor de gordura do leite, as variações ocorridas dentro de cada tratamento não foram estreitamente associadas como para o C18:1cis-11. Por exemplo, com relação ao C18:1trans-10, percebe-se um aumento inicial de sua concentração após o início do período de suplementação em ambos os tratamentos com OP, o que foi acompanhado pela queda no teor de gordura do leite. Entretanto, o teor de gordura do leite continua a cair na próxima coleta (TEMPO 3) em ambos os tratamentos, mas a concentração de C18:1trans-10 não aumenta no tratamento $A F+O P$. Além disso, a concentração 
de C18:1trans-10 no leite no tratamento BF+OP foi quase o dobro do observado no tratamento $\mathrm{AF}+\mathrm{OP}$ durante o período de suplementação, mas os teores de gordura do leite foram muito semelhantes. Discrepâncias no padrão de variação também foram observados para o CLA trans-10 cis-12 e o CLA trans-9 cis-11.

Este último é considerado o isômero reverso do CLA cis-9 trans-11, e o aumento da sua concentração no leite tem sido observado em vacas com DGL alimentadas com dietas contendo OP (Mikko Griinari, comunicação pessoal). Cabe aqui ressaltar que a determinação da concentração deste CLA no leite é absolutamente inovadora em âmbitos nacional e internacional. Embora a variação deste CLA no leite não tenha sido tão estreitamente relacionada à redução do teor de gordura como no caso do C18:1cis-11, o seu padrão de variação foi muito mais consistente do que o observado para o CLA trans-10 cis12. Isto sugere que o CLA trans-10 cis-12 não é, de fato, o principal inibidor da secreção de gordura do leite em vacas recebendo dietas contendo OP. Embora a concentração de C18:1trans-9 e C18:1trans-12 tenham apresentado um padrão de variação temporal semelhante ao observado para o C18:1cis-11 (dado não apresentado), estes isômeros já foram mostrados não afetar a síntese de gordura do leite (Rindsig e Schultz, 1974; Griinari et al., 2000).

Em suma, estes dados sugerem que o C18:1cis-11 pode estar fortemente envolvido com a DGL observada no presente experimento. Como este ácido graxo pode, teoricamente, ser formado pela redução do CLA trans-9 cis-11 por ação das bactérias ruminais, um envolvimento deste isômero do CLA com a DGL não pode ser descartado.

Para avaliarmos adicionalmente a relação entre estes ácidos graxos e a DGL, uma análise de regressão foi feita entre as suas concentrações e a DGL observada durante o período de suplementação (Figura 10). Neste caso, a DGL foi expressa em termos relativos, através da diferença entre o teor de gordura do leite observado em cada amostra durante o período de suplementação (S) e os valores observados nos respectivos animais durante o período basal (B). Desta 
forma, estaríamos corrigindo para eventuais diferenças iniciais no teor de gordura do leite dos animais.

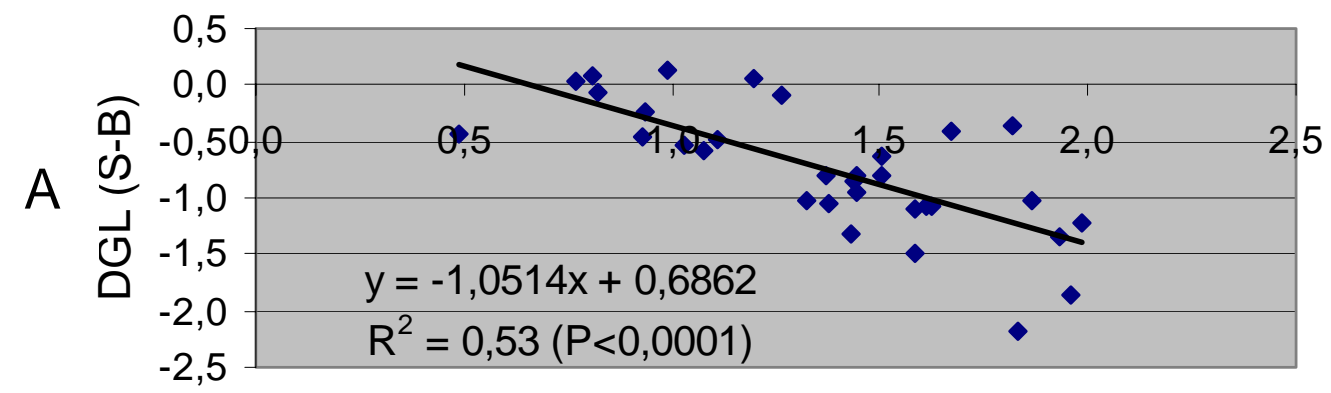

C18:1cis-11 (g/100g)

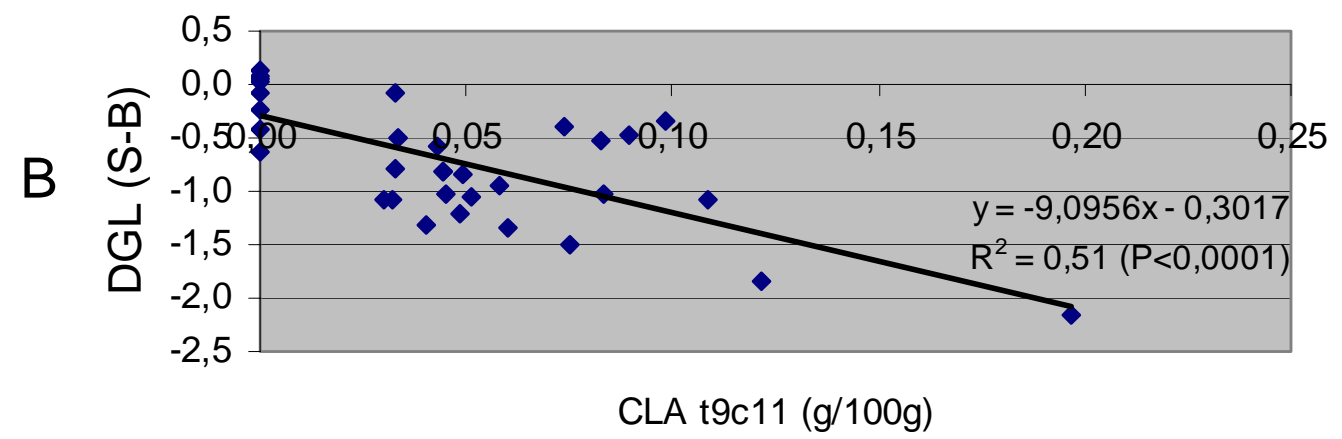

Figura 10 - Regressão entre as concentrações de C18:1cis-11 (A) e de CLA t9c11 (B) no leite e a DGL nos animais recebendo dietas com OP ( $S$ = teor de gordura do leite durante o período de Suplementação; $\mathrm{B}=$ teor de gordura do leite no período Basal) 
Como pode-se observar na figura acima, as concentrações de C18:1cis11 e de CLA trans-9 cis-11 explicaram, individualmente, mais do que 50\% da variação na DGL dos animais que receberam OP. Quando as mesmas regressões foram feitas para cada tratamento ( $\mathrm{AF}+\mathrm{OP}$ e $\mathrm{BF}+\mathrm{OP})$, os modelos foram também significativos $(P<0,05)$, mas a $D G L$ foi melhor explicada pelas concentrações de C18:1cis-11 e CLA trans-9 cis-11 quando o OP foi associado à dieta com baixa fibra. Esta diferença de resposta foi, claramente, devido à presença de um animal no grupo AF+OP que apresentou somente uma ligeira DGL ao longo do estudo, embora as concentrações de C18:1cis-11 e de CLA trans-9 cis-11 tivessem aumentado. A razão desta resposta talvez possa estar relacionada à problemas na coleta de amostras de leite, erros analíticos ou até mesmo fatores fisiológicos inerentes a cada animal (variação individual).

A relação entre a DGL e as concentrações de ácidos graxos trans no leite de animais recebendo OP foi também avaliada através de correlações no estudo de Loor et al. (2003). Consistente com o observado no presente experimento, estes autores observaram que alguns ácidos graxos trans são mais fortemente associados à DGL do que o C18:1trans-10 e o CLA trans-10 cis-12 em vacas alimentadas com dietas contendo OP. Em especial, as correlações foram mais altas e negativas para os ácidos graxos C18:1trans-9 e C18:1trans-12, embora estudos sugiram que estes ácidos graxos não são inibidores da secreção de gordura do leite (Bauman e Griinari, 2003).

Portanto, nossos resultados sugerem que, embora a concentração de muitos C18:1trans aumentem significativamente no leite dos animais alimentados com dietas contendo OP, um isômero de configuração cis (C18:1cis-11) pode estar direta ou indiretamente envolvido na DGL. Para verificarmos a possibilidade do C18:1cis-11 ser oriundo da redução do CLA trans-9 cis-11, uma regressão entre a concentração destes ácidos graxos foi realizada (Figura 11). 


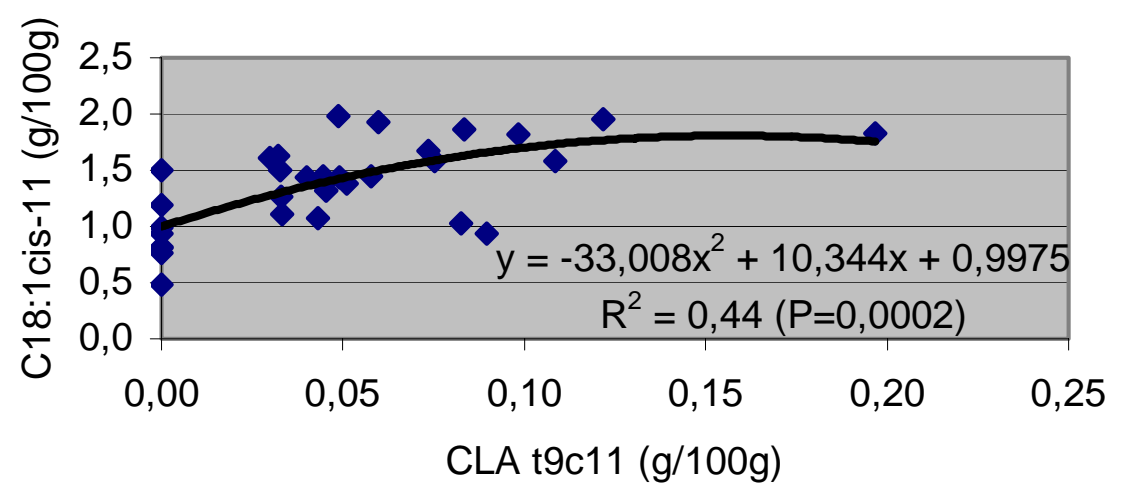

Figura 11 - Regressão entre as concentrações do CLA trans-9 cis-11 e do C18:1cis-11 no leite dos animais que receberam dietas contendo $\mathrm{OP}$

Como se pode perceber, existe uma grande probabilidade de que o aumento da concentração do CLA trans-9 cis-11 esteja associado ao aumento do C18:1cis11, o que sugere uma relação entre substrato e produto. Se ambas as duplas ligações do CLA t9c11 podem ser reduzidas no ambiente ruminal, espera-se ainda que as concentrações dos possíveis produtos (C18:1cis-11 e C18:1trans9) também sejam positivamente correlacionadas. A regressão observada entre as concentrações destes isômeros (Figura 12) é consistente com a idéia acima.

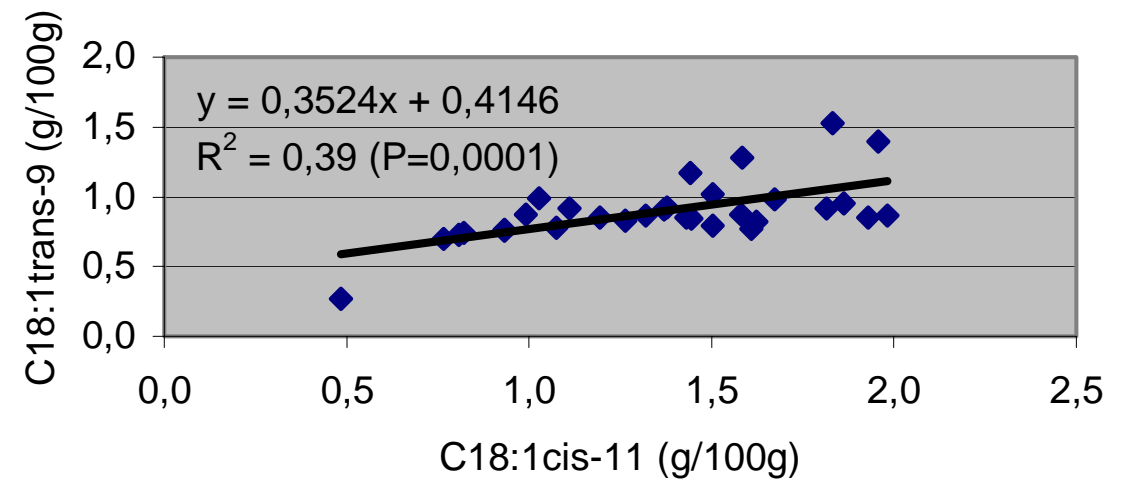

Figura 12 - Regressão entre as concentrações de C18:1t9 e C18:1c11 no leite do animais que receberam OP 
O C18:1trans-9 pode, entretanto, ser produzido a partir da isomerização do ácido oléico (Mosley et al., 2002). Esta seria uma via importante de formação de C18:1trans-9 no presente experimento, visto que o OP apresentou cerca de $31 \%$ de ácido oléico (Tabela 2). O ácidos linoléicos conjugados são normalmente formados pela biohidrogenação do ácido linoléico oriundo da dieta (Kepler et al., 1966). O CLA cis-9 trans-11 é o principal isômero de CLA no leite (Yarawecz et al., 1998), mas a quantidade de CLA trans-10 cis-12 aumenta sob condições de baixo $\mathrm{pH}$ ruminal (Griinari et al., 1998).

A via de formação do CLA trans-9 cis-11 no rúmen é ainda desconhecida. Entretanto, a menor concentração de ácido linoléico aliado à maior concentração deste CLA no leite dos animais que receberam dietas contendo OP (Tabela 11) sugere que o ácido linoléico pode ser seu precursor, direta ou indiretamente. A menor concentração de ácido linoléico no leite em resposta à dietas com OP é, provavelmente, resultado da menor concentração deste ácido graxo nas dietas que continham o óleo (Tabela 2). Entretanto, a maior concentração $(P=0,03)$ de ácido linoléico na dieta $\mathrm{BF}+\mathrm{OP}$ em relação à dieta $\mathrm{AF+OP}$ (Tabela 11) sugere que sua biohidrogenação ruminal pode ser inibida em condições de baixo $\mathrm{pH}$ ruminal, tal como sugerido por Chilliard et al. (2000). 
Tabela 11. Perfil de ácidos graxos do leite dos animais em resposta aos tratamentos $\mathrm{AF}+\mathrm{OP}(1), \mathrm{BF}(2)$ e $\mathrm{BF}+\mathrm{OP}(3)$

\begin{tabular}{|c|c|c|c|c|c|c|c|}
\hline \multirow[t]{2}{*}{ Ácido graxo } & \multicolumn{3}{|c|}{ Tratamentos } & \multirow[t]{2}{*}{ EPM } & \multicolumn{3}{|c|}{ Contrastes $^{\mathrm{a}}$} \\
\hline & $A F+O P$ & $\mathrm{BF}$ & $\mathrm{BF}+\mathrm{OP}$ & & $1 \times 2$ & $1 \times 3$ & $2 \times 3$ \\
\hline C18:0 & 2,03 & 7,88 & 2,49 & 0,83 & $\star \star$ & NS & $\star \star$ \\
\hline C18:1c9 & 8,87 & 22,3 & 10,8 & 1,82 & $\star \star *$ & $\dagger$ & ** \\
\hline C18:1c11 & 1,45 & 0,63 & 1,75 & 0,16 & $\star \star$ & NS & ** \\
\hline C18:1c12 & 0,15 & 0,41 & 0,15 & 0,05 & * & NS & * \\
\hline C18:1c13 & 0,23 & 0,13 & 0,18 & 0,02 & * & NS & NS \\
\hline C18:1c14/t16 & 0,22 & 0,38 & 0,19 & 0,03 & $\star \star$ & NS & $\star \star$ \\
\hline C18:1t4 & 0,04 & 0,01 & 0,04 & 0,01 & NS & NS & NS \\
\hline C18:1t5 & 0,05 & 0,02 & 0,06 & 0,01 & $\dagger$ & NS & * \\
\hline C18:1t6/8 & 0,43 & 0,37 & 0,77 & 0,12 & NS & NS & NS \\
\hline C18:1t9 & 0,90 & 0,37 & 1,02 & 0,09 & ** & NS & $\star \star$ \\
\hline C18:1t10 & 2,57 & 0,65 & 3,76 & 0,62 & NS & NS & * \\
\hline C18:1t11 & 8,60 & 1,92 & 11,4 & 1,50 & 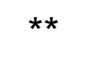 & NS & $\star *$ \\
\hline C18:1t12 & 1,05 & 0,54 & 0,96 & 0,09 & ** & NS & * \\
\hline C18:1t13 & 0,44 & 0,20 & 0,52 & 0,05 & * & NS & $\star \star$ \\
\hline C18:1t15 & 0,38 & 0,28 & 0,33 & 0,03 & NS & NS & NS \\
\hline C18:2 c9c12 & 1,62 & 3,08 & 2,24 & 0,20 & ** & * & ** \\
\hline C18:2 t9c12 & 0,27 & 0,21 & 0,24 & 0,03 & NS & NS & NS \\
\hline C18:3 c9c12c15 & 0,20 & 0,19 & 0,20 & 0,01 & NS & NS & NS \\
\hline CLA c9t11 & 2,74 & 0,58 & 3,13 & 0,38 & ** & NS & ** \\
\hline CLA t9c11 & 0,05 & 0,01 & 0,08 & 0,01 & NS & NS & * \\
\hline CLA t10c12 & 0,04 & 0,01 & 0,06 & 0,01 & * & NS & $\star \star$ \\
\hline
\end{tabular}

EPM = Erro padrão da média; $\mathrm{AF}=$ Alta Fibra; $\mathrm{BF}=$ Baixa Fibra; $\mathrm{OP}=$ Óleo de peixe

${ }^{a}$ Probabilidades das diferenças entre os tratamentos

NS = Não significativo $(P>0,1)$

$\dagger \mathrm{P}<0,1$

${ }^{*} P<0,05$

** $\mathrm{P}<0,01$ 


\subsection{Conclusões}

Apesar de incluído em pequena quantidade na dieta, o óleo de peixe (OP) reduziu o teor e a secreção de gordura do leite. Embora não tenha sido possível estudar adequadamente os efeitos de interação entre nível de fibra e a presença do óleo na dieta, a maior magnitude de redução no teor de gordura do leite observada nos animais que receberam OP em associação a uma dieta de baixa fibra sugere que pode haver uma interação entre estes fatores, já que a redução do nível de fibra da dieta, isoladamente, não afetou esta variável.

A ausência de DGL quando do fornecimento de dietas com baixo teor de fibra, sem a inclusão de OP, é consistente com os baixos teores de CLA trans-10 cis-12 e C18:1trans-10 no leite dos animais. Tal resposta deve-se, provavelmente, à baixa concentração de ácido linoléico nas dietas.

$\mathrm{O}$ consumo de MS foi reduzido em resposta ao OP, especialmente na dieta de baixa fibra, onde uma redução do peso vivo dos animais foi também observada. A redução do consumo é consistente com o conhecido efeito deletério do óleo sobre a digestão da fibra no rúmen e com a ampla redução da secreção de energia no leite (proporcionado pela queda do seu teor de gordura). Por outro lado, a redução do peso vivo dos animais no grupo BF+OP parece ser conseqüência de um menor enchimento ruminal, visto que o peso foi rapidamente recuperado após o retorno à dieta basal.

O fornecimento da dieta BF (sem OP), aumentou o teor de proteína do leite dos animais, enquanto que a inclusão de OP às dietas aumentou seu teor de lactose.

A secreção de gordura do leite foi amplamente reduzida ( $35 \%)$ nos animais que receberam OP, independentemente do teor de fibra da dieta. Esta redução foi causada por uma menor secreção tanto dos ácidos graxos sintetizados de novo quanto dos pré-formados, oriundos da circulação. A redução da secreção de ácidos graxos de cadeia média (C12-C16) foi maior em termos absolutos ( $\mathrm{g} / \mathrm{dia}$ ), mas foi mais pronunciada em termos relativos (\% em 
relação aos valores basais) para os ácidos graxos de cadeia curta (C4-C10). Entretanto, o nível de fibra da dieta afetou a magnitude destas respostas ao OP, de forma que a secreção dos ácidos graxos de cadeia longa foi maior, e os de cadeia média menor, respectivamente, na dieta de baixa fibra.

Estes resultados sugerem uma inibição da atividade de enzimas lipogênicas da glândula mamária nos animais que receberam OP. Esta inibição poderia envolver enzimas responsáveis pelos seguintes processos: 1) síntese de novo de ácidos graxos (acetil-CoA carboxilase e sintase de ácidos graxos), 2) captação de lipídios pré-formados do plasma (lipoproteína lipase), 3) dessaturação de ácidos graxos ( $\Delta-9$ dessaturase) ou ainda 4) esterificação dos ácidos graxos ao glicerol (glicerol-P acil transferase). Embora a atividade destas enzimas não tenham sido avaliadas diretamente neste experimento, a redução do índice de atividade da $\Delta-9$ dessaturase indica uma inibição desta enzima nos animais que receberam $\mathrm{OP}$.

Apesar da concentração de CLA trans-10 cis-12 no leite ter aumentado em resposta ao OP, a variação de sua concentração foi fracamente associada à DGL. Estes resultados indicam que o CLA trans-10 cis-12, ao contrário do que se observa em situações de clássica DGL, não é o principal inibidor da secreção de gordura do leite em vacas alimentadas com dietas suplementadas com OP, de forma que outros inibidores podem estar sendo formados nesta situação.

Apesar do aumento da concentração de inúmeros ácidos graxos C18:1 trans no leite dos animais que receberam OP, nossos resultados sugerem, de forma inédita, que o CLA trans-9 cis-11, e um provável produto de sua redução pelas bactérias ruminais, o C18:1cis-11, podem estar envolvidos nesta inibição. A análise da variação temporal da concentração destes ácidos graxos no leite em relação ao teor de gordura do leite, bem como as análises de regressão entre a concentração destes ácidos graxos e a DGL suportam nossa hipótese.

A concentração do CLA cis-9 trans-11 aumentou significativamente (> 300\%) nos animais que receberam OP. Embora o aumento do aporte de C18:1 trans-11 possa aumentar a concentração de CLA c9t11 no leite devido à síntese 
endógena, nossos resultados indicam que parece haver um limite para este incremento.

O aumento da concentração de ácidos graxos trans no leite do animais que receberam OP é acompanhado por uma redução na concentração de ácido esteárico (C18:0), sugerindo uma inibição da última etapa da biohidrogenação ruminal dos ácidos graxos poliinsaturados presentes na dieta. A redução de C18:0 é consistente com a menor concentração de ácido oléico (C18:1c9) no leite dos animais tratados com OP, visto que grande parte deste último é oriundo da dessaturação de C18:0 por ação da enzima $\Delta-9$ dessaturase. 


\section{CONCLUSÕES GERAIS}

Visto que há uma crescente valorização da proteína do leite no mercado mundial, fatores que possam aumentar sua secreção no leite são de grande interesse. Pesquisas prévias conduzidas pelo nosso grupo demonstraram que o fornecimento de CLA protegido para vacas a pasto foi capaz de aumentar tanto o teor quanto a secreção deste componente do leite.

O nosso primeiro experimento foi delineado para testar a hipótese de que um maior suprimento de proteína na dieta poderia maximizar o aumento da secreção de proteína do leite em resposta ao CLA. Entretanto, os resultados obtidos mostraram que o método utilizado para proteção ruminal do CLA foi ineficiente, de forma que não foi possível testar nossa hipótese. Apesar deste relativo insucesso, outro resultado, não menos importante, foi gerado a partir dos dados obtidos neste primeiro estudo.

Interessantemente, o teor de gordura do leite dos animais tratados com CLA foi menor do que o tratados Lac100, apesar da concentração de CLA trans-10 cis-12 no leite ter aumentado na mesma magnitude em ambos os tratamentos. Isto sugere que algum outro isômero presente no produto, ou algum intermediário de sua biohidrogenação ruminal, pode também exercer um efeito inibitório sobre a síntese de gordura do leite. O fato do CLA trans-10 cis12 ter explicado somente metade da variação do teor de gordura do leite indica ainda que outros fatores foram responsáveis pela DGL em resposta tanto ao fornecimento do CLA quanto do Lac100. A identificação de tais fatores é 
importante em situações onde a manipulação da composição do leite pode ser de interesse.

O segundo experimento mostrou que o fornecimento de OP, mesmo em pequenas quantidades, reduziu sensivelmente a secreção de gordura do leite de vacas em lactação. Entretanto, diferentemente do observado em outras condições dietéticas (baixa fibra + lipídios vegetais), o aumento da concentração de CLA trans-10 cis-12 não foi capaz de explicar a DGL decorrente do fornecimento de OP e, além disso, tal resposta foi observada mesmo na dieta com nível adequado de fibra. De maneira inédita, os resultados apresentados neste estudo indicaram que o CLA trans-9 cis-11, e um provável produto de sua biohidrogenação, o C18:1 cis-11, são possíveis inibidores da síntese de gordura do leite em vacas recebendo OP. A obtenção de fontes purificadas destes dois ácidos graxos será fundamental para comprovar nossa hipótese, assim como para determinar os mecanismos envolvidos na inibição.

Apesar dos nossos resultados indicarem uma redução da atividade da enzima $\Delta-9$ dessaturase, a ampla redução da secreção tanto dos ácidos graxos sintetizados na glândula mamária quanto dos pré-formados indicam que a inibição da síntese de gordura deve abranger outros mecanismos. 


\section{REFERÊNCIAS BIBLIOGRÁFICAS}

AMERICAN OIL CHEMISTS' SOCIETY. Official methods and recommended pratices. 5 ed. Champaign, 1991.

ABUGHAZALEH, A.A.; SHINGOETHE, D.J.; HIPPEN, A.R.; KALSCHEUR, K.F. Milk conjugated linoleic acid respose to fish oil supplementation of diets differing in fatty acid profile. Journal of Dairy Science, v.86, p.3648-3660, 2003.

AROLA, A.; SHINGFIELD, K.J.; VANHATALO, A.; TOIVONEN, V.; HUHTANEN, P.; GRIINARI, J.M. Biohydrogenation shift and milk fat depression in lactating dairy cows fed increasing levels of fish oil. Journal of Animal Science, v.80, Suppl.1. Journal of Dairy Science, v.85, Suppl.1, p.143, 2002.

BAUMAN, D.E. Regulation of nutrient partitioning during lactation: homeostasis and homeorhesis revisited. In: Ruminant Physiology: Digestion, Metabolism and Growth, and Reproduction, New York: PJ Conje, 2000. p.311-327.

BAUMAN, D.E.; GRIINARI, J.M. Regulation and nutritional manipulation of milk fat: low-fat milk syndrome. Livestock Production Science, v.70, p.15-29, 2001.

BAUMAN, D.E.; GRIINARI, J.M. Nutritional regulation of milk fat synthesis. Annual Review of Nutrition, v.23, p.203-227, 2003. 
BAUMAN, D.E.; DAVIS, C.L.; BUCHOLTZ, H.F. Propionate production in the rumen of cows fed either a control or high grain, low fiber diet. Journal of Dairy Science, v.54, p.1282-1287, 1971.

BAUMAN, D.E.; CORL, B.A.; PETERSON, D.G. The biology of conjugated linoleic acids in ruminants. In: Advances in Conjugated Linoleic Acid Research, v.2, JL Sebedio, 2003. p.1-16.

BAUMAN, D.E.; BAUMGARD, L.H.; CORL, B.A.; GRIINARI, J.M. Biosynthesis of conjugated linoleic acid in ruminants. Proceedings of the American Society of Animal Science, v.48, p.1-15, 1999.

BAUMAN, D.E.; CORL, B.; BAUMGARD, L.H.; GRIINARI, J.M. Conjugated linoleic acid (CLA) and the dairy cow. In: Recent Advances in Animal Nutrition, Nottingham: PC Garnsworthy, 2001. p.221-250.

BAUMGARD, L.H.; SANGSTER, J.K.; BAUMAN, D.E. Milk fat synthesis in dairy cows is progressively reduced by increasing supplemental amounts of trans10, cis-12 conjugated linoleic acid (CLA). Journal of Nutrition, v.131, p.1764-1769, 2001.

BAUMGARD, L.H.; CORL, B.A.; DWYER, D.A.; SAEBO. A.; BAUMAN, D.E. Identification of the conjugated linoleic acid isomer that inhibits fat synthesis. American Journal Physiology Regulatory Integrative Comparative Physiology, v.278, p.R179-R184, 2000.

BAUMGARD, L.H.; MATITASHVILI, E.; CORL, B.A.; DWYER, D.A.; BAUMAN, D.E. Trans-10, cis-12 conjugated linoleic acid decreases lipogenic rates and expression of genes involved in milk lipid synthesis in dairy cows. Journal of Dairy Science, v.85, p.2155-2163, 2002. 
BERNAL-SANTOS, G.; PERFIELD, J.W.; OVERTON, T.R.; BAUMAN, D.E. Production responses of dairy cows to dietary supplementation with conjugated linoleic acid (CLA) during the transition period and early lactation. Journal of Dairy Science, v.84, Suppl.1, p.82, 2001.

BLOCK, S.M.; JENKINS, T.C. The use of prilled fat to coat and protect amino acids from ruminal degradation. Journal Science Food Agriculture, v.65, p.441-447, 1994.

CANT, J.P.; FREDEEN, A.H.; MACINTYRE, T.; GUNN, J.; CROWE, N. Effect of fish oil and monensin on milk composition in dairy cows. Canadian Journal of Animal Science, v.77, p.125-131, 1997.

CHILLIARD, Y.; FERLAY, A.; DOREAU, M. Effect of different types of forages, animal fat or marine oils in cow's diet on milk fat secretion and composition, especially conjugated linoleic acid (CLA) and polyunsaturated fatty acids. Livestock Production Science, v.70, p.31-48, 2001.

CHILLIARD, Y.; FERLAY, A.; MANSBRIDGE, R.M.; DOREAU, M. Ruminant milk fat plasticity: nutritional control of saturated, polyunsaturated, trans and conjugated fatty acids. Annales de Zootechnia, v.49, p.181-205, 2000.

CHILLIARD, Y.; CHARDIGNY, J.M.; CHABROT, J.; OLLIER, A.; SÉBÉDIO, J.L.; DUREAL, M. Effects of ruminal or postruminal fish oil supply on conjugated linoleic acid (CLA) content of cow milk fat. Proceedings of Nutrition Society, v.58, p.70, 1999.

CHIN, S.F.; LIU, W.; STORKSON, J.M.; HA, Y.L.; PARIZA, M.W. Dietary sources of conjugated dienoic isomers of linoleic acid, a newly recognized class of anticarcinogens. Journal of Food Composition and Analysis, v.5, p.185-197, 1992. 
CHIN, S.F.; STORKSON, J.M.; ABRIGHT, K.J.; COOK, M.E.; PARIZA, M.W. Conjugated linoleic acid is a growth factor for rats as shown by enhanced weight gain and improved feed efficiency. Journal of Nutrition, v.124, p.2344-2349, 1994.

CHOUINARD, P.I.; CORNEAU, L.; SAEBO, A.; BAUMAN, D.E. Milk yield and composition during abomasal infusion of conjugated linoleic acids in dairy cows. Journal of Dairy Science, v.82, p.2737-2745, 1999.

CHOUINARD, P.Y.; CORNEAU, L.; BUTLER, W.R.; CHILLIARD, Y.; DRACKLEY, J.K.; BAUMAN, D.E. Effect of dietary lipid source on conjugated linoleic acid concentration in milk fat. Journal of Dairy Science, v.84, p.680690, 2001.

CHRISTIE, W.W. A simple procedure for rapid transmethylation of glycerolipids e cholesterol esters. Journal of Lipid Research, v.23, p.1072, 1982.

COOK, M.E.; MILLER, C.C.; PARK, Y.; PARIZA, M. Immune modulation by altered nutrient metabolism: nutritional control of immune-induced growth depression. Poultry Science, v.72, p.1301-1305, 1993.

CORL, B.A.; CHOUINARD, P.Y.; BAUMAN, D.E.; DWYER, D.A.; GRIINARI, J.M.; NURMELA, K.V. Conjugated linoleic acid in milk fat of dairy cows originates in part by endogenous synthesis from trans-11 octadecenoic acid. Journal of Dairy Science, v.81, Suppl.1, p.60, 1998.

CORL, B.A.; BAUMGARD L.H;. DWYER D.A.; GRIINARI, J.M.;. PHILIPS, B.S.; BAUMAN, D.E. The role of delta-9-desaturase in the production of cis-9, trans-11. Journal of Nutritional Biochemistry, v.12, p.622-630, 2001. 
CORL, B.A.; BAUMGARD L.H; GRIINARI, J.M.; DELMONTE, P.; MOREHOUSE, K.M.; YURAWECZ, M.P.; BAUMAN, D.E. Trans-7 cis-9 CLA is synthesized endogenously by $\Delta 9$-desaturase in dairy cows. Lipids, v.37, p.681-688, 2002.

DAVIS, C.L.; BROWN, R.E. Low-fat milk syndrome. In: Physiology of Digestion and Metabolism in the ruminant, England: AT Phillipson, 1970. p.545-565.

DONOVAN, D.C.; SCHINGOETHE, D.J.; BAER, R.J.; RYALI, J.; HIPPEN, aR.; FRANKLIN, S.T. Influence of dietary fish oil on conjugated linoleic acid and other fatty acids in milk fat from lactating dairy cows. Journal of Dairy Science, v.83, p.2620-2628, 2000.

DOREAL, M.; CHILLIARD, Y.; RULQUIN, H.; DEMEYER, D.I. Manipulation of milk fat in dairy cows. In: RECENT ADVANCES IN ANIMAL NUTRITION. Nottingham: PC Garnsworthy, 1999. p.81-109.

ENJALBERT, F.; NICOT, M. C.; BAYOURTHE, C.; MONCOULON, R.; Duodenal infusions of palmitic, stearic, or oleic acids differently affect mammary gland metabolism of fatty acids in lactating dairy cows. Journal of Nutrition, v.128, p.1525-1532, 1998.

FRITSCHE, J.; FRITSCHE, S.; SOLOMON, M.B.; MOSSOBA, M.M.; YURAWECZ, M.P.; MOREHOUSE, K.; KU, Y. Quantitative determination of conjugated linoleic acid isomers in beef fat. European Journal of Lipid Science, v.102, p.667-672, 2000.

GAYNOR, P.J.; WALDO, D.R.; CAPUCO, A.V.; ERDMAN, R.A.; DOUGLASS, L.W.; TETER, B.B. Milk fat depression, the glucogenic theory, and transC18:1 fatty acids. Journal of Dairy Science, v.78, p.2008-2015, 1995. 
GAYNOR, P.J.; ERDMAN, R.A.; TETER, B.B.; SAMPUGNA, J.; CAPUCO, A.V.; WALDO, D.R.; HAMOSH, M. Milk fat yield and composition during abomasal infusion of cis or trans octadecenoates in Holstein cows. Journal of Dairy Science, v.77, p.157-165, 1994.

GIESY, J.G.; MCGUIRE, M.A.; SHAFII, B.; HANSON, T.W. Effect of dose of calcium salts of conjugated linoleic acid (CLA) on percentage and fatty acid content of milk fat in midlactation Holstein cows. Journal of Dairy Science, v.85, p.2023-2029, 2002.

GIESY, J.G.; VISWANADHA, S.; HANSON, T.W.; FALEN, L.R.; McGUIRE, M.A.; SKARIE, C.H.; VINCl, A. Effects of calcium salts of conjugated linoleic acid (CLA) on estimated energy balance in Holstein cows in early lactation. Journal of Dairy Science, v.82, Suppl.1, p.74, 1999.

GIVENS, D.I.; COTTRILL, B.R.; DAVIES, M.; LEE, P.; MANSBRIDGE, R.; MOSS, A.R. Sources of n-3 polyunsaturated fatty acids additional to fish oil for livestock diets. A review. Nutrition Abstract Review, v.70, p.1-19, 2000.

GRIINARI, J.M.; BAUMAN, D.E. Biosynthesis of conjugated linoleic acid and its incorporation into meat and milk in ruminants, In: ADVANCES IN CONJUGATED LINOLEIC ACID RESEARCH, Champain, 1999. Proceedings. Champaign: AOCS Press, 1999. p.180-200.

GRIINARI, J.M.; BAUMAN, D.E.; CHILLIARD, Y.; PERAJOKI, P.; NURMELA, K. Dietary influences on conjugated linoleic acids (CLA) in bovine milk fat. In: MEETING OF THE EUROPEAN SECTION OF AOCS, Helsinki, 2000. Proceedings. Helsinki: AOCS, 2000. p.97. 
GRIINARI, J.M.; McGUIRE, M.A.; DWYER, D.A.; BAUMAN, D.E.; BARBANO, D.M.; HOUSE, W.A. The role of insulin in the regulation of milk protein synthesis in dairy cows. Journal of Dairy Science, v.80, p. 2361-2371, 1997.

GRIINARI, J.M.; DWYER, D.A.; MCGUIRE, M.A.; BAUMAN, D.E.; PALMQUIST, D.L.; NURMELA, K.V.V. Trans-octadecenoic acids and milk fat depression in lactating dairy cows. Journal of Dairy Science, v. 81, p.1251-1261, 1998.

GRIINARI, J.M.; CORI, B.; LACY, S.; CHOUINARD, P.; NURMELA, K.; BAUMAN, D. Conjugated linoleic acid is synthesized endogenously in lactating dairy cows by delta-9 desaturase. Journal of Nutrition, v.130, p.2285-2291, 2000.

GULATI, S.K.; ASHES, J.R.; SCOTT, T.W. Hydrogenation of eicosapentaenoic and docosahexaenoic acids and their incorporation into milk fat. Animal feed Science and Technology, v.79, p.57-64, 1999.

GULATI, S.K.; McGRATH, S.; WYNN, P.C.; SCOTT, T.W. Preliminary results on the relative incorporation of docosahexaenoic and eicosapentaenoic acids into cows milk from two types of rumen protected fish oil. International Dairy Journal, v.13, p.339-343, 2003.

GULATI, S.K.; KITESSA, S.M.; ASHES, J.R.; FLECK, E.; BYERS, E.B.; BYERS, Y.G.; SCOTT, T.W. Protection of conjugated linoleic acids from ruminal hydrogenation and their incorporation into milk fat. Animal Feed Science and Technology, v.86, p.139-148, 2000.

HARA, A.; RADIN, N.S. Lipid extraction of tissues with low-toxicity solvent. Analytical Biochemistry, v.90, p. 420-426. 1978. 
HAYASHI, A.A.; MEDEIROS, S.R.; LANNA, D.P.D. Effects of conjugated linoleic acid (CLA) on milk fatty acid profiles and activities of lipogenic enzymes in the mammary gland, liver and adipose tissue of lactating rats. Journal of Dairy Science, v.85, Suppl.1, p.10, 2002.

HURTAUD, C.; RULQUIN, H.; VERITE, R. Effects of graded duodenal infusions of glucose on yield and composition of milk from dairy cows. 1. Diets based on corn silage. Journal of Dairy Science, v.81, n.12, p.3239-3247, 1998.

JAHREIS, G.; FRITSCHE, J.; STEINHART, H.; Conjugated linoleic acid in milk fat: high variation depends on production system. Nutrition Research, v.17, p.1479-1484, 1997.

JENKINS, T.C. Lipid metabolism in the rumen. Journal of Dairy Science, v.76, p.3851-3863, 1993.

JENKINS, T.C.; PALMQUIST, D.L. Effect of fatty acids or calcium soaps on rumen and total nutrient digestibility of dairy rations. Journal of Dairy Science, v.67, p.978-986, 1984.

KEADY, T.W.J.; MAYNE, C.S. The effects of level of fish oil inclusion in the diet on rumen digestion and fermentation parameters in cattle offered grass silage based diets. Animal Feed Science and Technology, v.81, p.57-68, 1999.

KELLY, M.L.; BERRY, J.R.; DWYER, D.A.; GRIINARI, J.M.; CHOUINARD, P.Y.; VAN AMBURGH, M.E.; BAUMAN, D.E. Dietary fatty acid sources affect conjugated linoleic acid concentration in milk from lactating dairy cows. Journal of Nutrition, v.128, p.881-885, 1998.

KENNELY, J.J. The fatty acid composition of milk fat as influenced by feeding oilseeds. Animal Feed Science and Technology, v.60, p.137-152, 1996. 
KENNELLY, J.J.; GLIMM, D.R.; OZIMEK, L. Milk composition in the cow. In: CORNELL NUTRITION CONFERENCE FOR FEED MANUFACTURERS, Ithaca, 1999. Proceedings. Ithaca: Cornell University, p.1-21.

KEPLER, C.R.; HIRONS, K.P.;McNEILL, J.J.; TOVE, S.B. Intermediates and products of the biohydrogenation of linoleic acid by Butyrivibrio fibrisolvens. Journal of Biological Chemistry, v.241, p.1350-1354,1966.

KESLEY, J.A.; CORL, B.A.; COLLIER, R.J.; BAUMAN, D.E. The effect of breed, parity, and stage of lactation on conjugated linoleic acid (CLA) in milk fat from dairy cows. Journal of Dairy Science, v.86, p.2588-2597, 2003.

KRAMER, J.K.G.; FELLNER, V.; DUGAN, M.E.R.; SAUER, F.D.; MOSSOBA, M.M.; YURAWECZ, M.P. Evaluating acid and base catalysts in the methylation of milk and rumen fatty acids with special emphasis on conjugated dienes and total trans fatty acids. Lipids, v.32, p.1219-1228, 1997.

LEMOSQUET, S.; RIDEAU, N.; RULKIN, H.; FAVERDIN, P.; SIMON, J.; VERITE, R. Effects of a duodenal glucose infusion on the relationship between plasma concentration of glucose and insulin in dairy cows. Journal of Dairy Science, v.80, p. 2854-2865, 1997.

LOOR, J.J.; HERBEIN, J.H. Exogenous conjugated linoleic acid isomers reduce bovine milk fat concentration and yield by inhibiting de novo fatty acid synthesis. Journal of Nutrition, v.128, p.2411-2419, 1998.

LOOR, J.J.; CHARDIGNY, J.M.; CHABROT, J.; DOREAU, M.; OLLIER, A.; SEBEDIO, J.L.; CHILLIARD, Y. Trans-fatty acids (tFA), CLA isomers, and milk fat depression (MFD) in dairy cows receiving incremental doses of fish oil. Journal of Dairy Science, v.86, Suppl.1; Journal of Animal Science, v.81, Suppl.1, p.272, 2003. 
MACKLE, T.R.; DWYER, D.A.; INGVARTSEN, K.L.; CHOUINARD, P.Y.; LYNCH, J.M.; BARBANO, D.M.; BAUMAN, D.E. Effects of insulin and amino acids on milk protein concentration and yield from dairy cows. Journal of Dairy Science., v.82, p.1512-1524, 1999.

MCCLYMONT, G.L.; VALLANCE, S. Depression of blood glycerides and milk fat synthesis by glucose infusion. Proceedings of the Nutrition Society, v.21, p.151, 1962.

MCGUIRE M.A.; GRIINARI J.M.; DWYER D.A.; BAUMAN, D.E. Role of insulin in the regulation of mammary synthesis of fat and protein. Journal of Dairy Science, v.78, p.816-824, 1995.

McGUIRE, M.A; McGUIRE, M.K.; McGUIRE, M.S.; GRIINARI, J.M. Bovine Acid: The natural CLA. In: CORNELL NUTRITION CONFERENCE FOR FEED MANUFACTURERS. Ithaca, 1997. Proceedings. Ithaca: Cornell University, p.217-226.

MEDEIROS, S.R. Ácido linoléico Conjugado: teores nos alimentos e seu uso no aumento da produção de leite com maior teor de proteína e perfil de ácidos graxos modificado. Piracicaba, 2002. 98p. Dissertação (Doutorado) - Escola Superior de Agricultura "Luiz de Queiroz", Universidade de São Paulo.

MEDEIROS, S.R.; OLIVEIRA, D.E.; AROEIRA, L.J.M.; McGUIRE, M.A.; BAUMAN, D.E.; LANNA, D.P.D. The effect of long-term supplementation of conjugated linoleic acid to dairy cows grazing tropical pasture. Journal of the American Society of Dairy Science. Baltimore, p.169, 2000. 
METCALF, J.A.; CROMPTON, L.A.; WRAY-CAHEN, D.; LOMAX, M.A.; SUTTON, J.D.; BEEVER, D.E.; McRAE, J.C.; BEQUETTE, B.J.; BACKWELL, F.R.C.; LOBLEY, G.E. Responses in milk constituents to intravascular administration of two mixtures of amino acids to dairy cows. Journal of Dairy Science, v.79, 1996.

MOSLEY, E.E.; POWELL, G.L.; RILEY, M.B.; JENKINS, T.C. Micribial biohydrogenation of oleic acid to trans isomers in vitro. Journal of Lipid Research, v.43, p.290-296, 2002.

MURPHY, J.J.; O'MARA, F.; Nutritional manipulation of milk protein concentration and its impact on the dairy industry. Livestock Production Science, v.35, p.117-134, 1993.

OFFER, N.W.; MARSDEN, M.; PHIPPS, R.H. Effect of oil supplementation of a diet containing a high concentration of starch on levels of trans fatty acids and conjugated linoleic acid in bovine milk. Animal Science, v.73, p.533-540, 2001.

OFFER, N.W.; MARSDEN, M.; DIXON, J.; SPEAKE, B.K.; THACKER, F.E.; Effect of dietary fat supplements on levels of $n-3$ polyunsaturated fatty acids, trans acids and conjugated linoleic acid in bovine milk. Animal Science, v.69, p.613-625, 1999.

OSTROWSKA, E.; MURALITHARAN, M.; CROSS, R.F.; BAUMAN, D.F.; DUNSHEA, F.R. Dietary conjugated linoleic acid increase lean tissue and decrease fat deposition in growing pigs. Journal of Nutrition, v.129, p. 2037-2042, 1999.

PALMQUIST, D.L.; MATTOS, W. Turnover of lipoproteins and transfer to milk fat of dietary (1-carbon-14) linoleic acid in lactating cows. Journal of Dairy Science, v.61, p.561-565, 1978. 
PARIZA, M.W.; PARK, Y.; COOK, M.E. The biologically active isomers of conjugated linoleic acid. Progress in Lipid Research, v.40, p.283-298, 2001.

PARK, Y.; ALBRIGHT, K.L.; LIU, W.; STORKSON, J.M.; COOK, M.E.; PARIZA, M.W. Effect of conjugated linoleic acid on body composition in mice. Lipids, v.32, p.853-858, 1997.

PARODI, P.W. Cows' milk fat components as potential anticarcinogenic agents. Journal of Nutrition, v.127, p. 1055-1060, 1997.

PERFIELD, J.W.; SAEBO, A.; BAUMAN, D.E.; Effects of trans-8 cis-10 CLA and cis-11 trans-13 CLA on milk fat synthesis. Journal of Animal Science, v.81, Suppl.1, p.10, 2003.

PERFIELD J.W.; BERNAL-SANTOS, G.; OVERTON, T.R.; BAUMAN, D.E. Effects of dietary supplementation of rumen-protected conjugated linoleic acid in dairy cows during established lactation. Journal of Dairy Science, v.85, p.2609-2617, 2002.

PETERSON, D.G.; BAUMGARD, L.H.; BAUMAN, D.E. Short communication: Milk fat response to low doses of trans-10, cis-12 conjugated linoleic acid (CLA). Journal of Dairy Science, v.85, p.1764-1766, 2002.

PIPEROVA, L.S.; SAMPUGNA, J.; TETER, B.B.; KALSCHEUR, K.F.; YURAWECZ, M.P.; KU. Y.; MOREHOUSE, K.M.; ERDMAN, R.A. Duodenal and milk trans octadecenoic acid and conjugated linoleic acid (CLA) isomers indicate that postabsortive synthesis is the predominant source of cis-9containing CLA in Lactating dairy cows. Journal of Nutrition, v.132, p.12351241, 2002. 
PIPEROVA, L.S.; TETER, B.B.; BRUCKENTAL, I.;SAMPUGNA, J.; MILLS, S.T.; YURAWECZ, M.P.; FRITSCHE, J.; KU, K.; ERDMAN, R.A. Mammary lipogenic enzyme activity, trans fatty acids and conjugated linoleic acids are altered in lactating dairy cows fed a milk fat - depressing diet. Journal of Nutrition, v.130, p.2568-2574, 2000.

RULQUIN, H.R.; VERITE, G.; GUINARD, J.; PISULEWSKI, P.M. Dairy cow'S requirements for amino acids. In: ANIMAL SCIENCE RESEARCH AND DEVELOPMENT: MOVING TOWARD A NEW CENTURY. Ottawa, 1995. Proceedings. Ottawa: Ed. Ivan, M. 1995, p.143-160.

SAS INSTITUTE SAS/STAT: Guide for personal computers. Cary: 2000. 1v.

SEHAT, N.; KRAMER, J.K.G.; MOSSOBA, M.M.; YURAWECZ, M.P.; ROACH, J.A.G.; EULITZ, K.; MEREHOUSE, K.M.; KU, Y. Identification of conjugated linoleic acid isomers in cheese by gas chromatography, silver ion high performance liquid chromatography and masss spectral reconstructed ion profiles. Comparasion of chromatographic elutions sequences. Lipids, v.33, p.963-971, 1998.

SHINGFIELD, K.J.; AHVENJARVI, S.; TOIVONEN, V.; AROLA, A.; HUHTANEN, P.; GRIINARI, J.M. Fish oil inhibits the biohydroganation of fatty acids in the rumen causing na increase in milk trans-octadecenoic and conjugated linoleic acid content. Journal of Animal Science, v.80, Suppl.1, Journal of Dairy Science, v.85, Suppl.1, p.143, 2002.

SUKHIJA, P.S.; PALMQUIST, D.L. Dissiciation of calcium soaps of long-chain fatty acids in rumen fluid. Journal of Dairy Science, v.73, p.1784-1787, 1990.

SUTTON, J.D. Altering milk composition by feeding. Journal of Dairy Science, v.72, p.2801-2814, 1989. 
VAN SOEST, P.J. Nutrition ecology of the ruminant. 2. Ed. Ithaca: CORNELL UNIVERSITY, 1994. 476p.

WHITLOCK, L.A.; SCHINGOETHE, D.J.; HIPPEN, A.R.; KALSCHEUR, R.J.; BAER, R.J.; RAMASWAMY, N.; KASPERSON, K.M. Fish oil and extruded soybeans fed in combination increase conjugated linoleic acids in milk of dairy cows more than when fed separately. Journal of Dairy Science, v.85, p.234-243, 2002.

WILDMAN, E.E.; JONES, G.M.; WAGNER, P.E.; BOWMAN, R.L.; TROUTT, H.F.; LESCH, T.N. Dairy cows body condition score and its relationship to selected production characteristics. Journal of Dairy Science, v.65, p.465$501,1982$.

WILLIAMS, C.M. Dietary fatty acids and human health. Annales de Zootechnia, v.49, p.165-180, 2000. 